University of Nebraska - Lincoln

DigitalCommons@University of Nebraska - Lincoln

Nutrition \& Health Sciences Dissertations \& Theses

Nutrition and Health Sciences, Department of

Spring 4-2013

\title{
A Mixed Methods Approach to Evaluate KidQuest, a Traditional Classroom Obesity Prevention Intervention, in an Afterschool Program: A Pilot Study
}

Amy M. Wehbe

University of Nebraska-Lincoln, amy.texley@huskers.unl.edu

Follow this and additional works at: https://digitalcommons.unl.edu/nutritiondiss

Wehbe, Amy M., "A Mixed Methods Approach to Evaluate KidQuest, a Traditional Classroom Obesity Prevention Intervention, in an Afterschool Program: A Pilot Study" (2013). Nutrition \& Health Sciences Dissertations \& Theses. 40.

https://digitalcommons.unl.edu/nutritiondiss/40

This Article is brought to you for free and open access by the Nutrition and Health Sciences, Department of at DigitalCommons@University of Nebraska - Lincoln. It has been accepted for inclusion in Nutrition \& Health Sciences Dissertations \& Theses by an authorized administrator of DigitalCommons@University of Nebraska - Lincoln. 


\title{
A MIXED METHODS APPROACH TO EVALUATE KIDQUEST, A TRADITIONAL CLASSROOM OBESITY PREVENTION INTERVENTION, IN AN AFTERSCHOOL PROGRAM: A PILOT STUDY
}

\author{
By
}

Amy M. Wehbe

\section{A THESIS}

Presented to the Faculty of The Graduate College at the University of Nebraska In Partial Fulfillment of Requirements For the Degree of Master of Science Major: Nutrition and Health Sciences

Under the Supervision of Professor Julie Albrecht

\author{
Lincoln, Nebraska
}

April 2013 


\section{A MIXED METHODS APPROACH TO EVALUATE KIDQUEST, A TRADITIONAL CLASSROOM OBESITY PREVENTION INTERVENTION, IN AN AFTERSCHOOL PROGRAM: A PILOT STUDY}

Amy M. Wehbe, M.S.

University of Nebraska, 2013

Advisor: Julie Albrecht

Over 1.4 million middle school adolescents participate in afterschool programs each year. While most of the obesity prevention interventions focus on the traditional school day, the afterschool setting should not be overlooked. A pilot study was conducted using KidQuest, a traditional classroom nutrition and physical activity intervention for early adolescents ages 10 to 12 based on the social cognitive theory, in an afterschool setting. The purpose of the pilot study was to evaluate the effectiveness of using a nutrition and physical activity intervention developed for the traditional school day in an afterschool setting. The desired outcome of this mixed-methods study with explanatory design was for participants to use nutrition related knowledge and skills learned to improve self-efficacy and change behavior. Outcomes of 24 participants were measured using pre/post surveys and focus groups/structured interview. While no statistical significance was identified, behavior change was noted in the focus groups/structured interview. In the focus groups/structured interview, participants reported that the intervention: 1) Increased knowledge in identifying healthy snacks/meals and food label reading and 2) Promoted family involvement. Implementation of the intervention in an afterschool program posed challenges with participant attendance and compliance. Evaluation of the pilot study provided direction to alter future programming by continuing the structured physical activity time in the 
afterschool program while re-directing the nutrition intervention towards the traditional school day. Implications for future research include identifying strategies for implementing traditional school nutrition interventions in the afterschool setting and determining avenues to reach youth consistently in the afterschool hours. 


\section{Author's Acknowledgments}

Special thanks to my advisor Dr. Julie Albrecht and committee members Dr. Michelle Krehbiel, Dr. Shinya Takahashi for guiding me and providing direction for the completion of the project. I would also like to thank Dr. Tim Carr, Jean Ann Fischer, Melissa Wallinga, and the Nebraska Evaluation and Research (NEAR) Center at the University of Nebraska-Lincoln.

\section{Project Funding Source}

This project was funded by: National Research Initiative Grant no. 2011-67002-30202 from the Food and Agriculture Division of Nutrition. 
Table of Contents

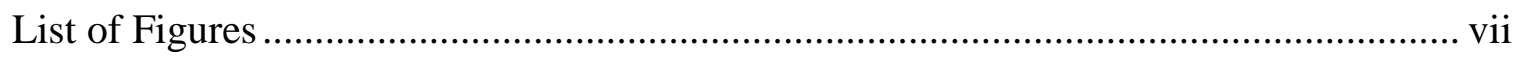

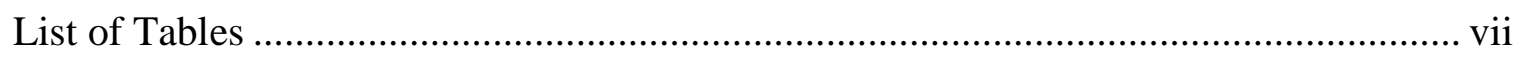

List of Appendices .......................................................................................... viii

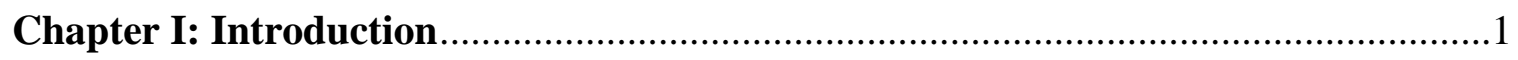

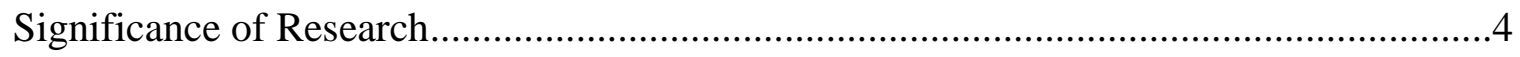

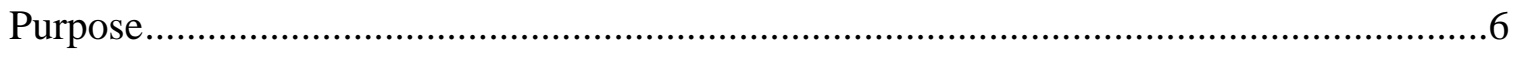

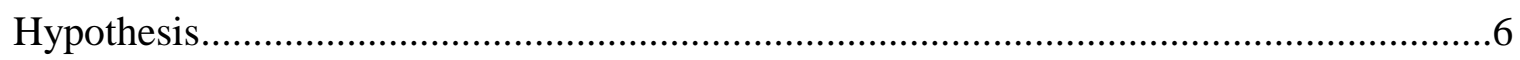

$\begin{array}{ll}\text { Objectives } & 6\end{array}$

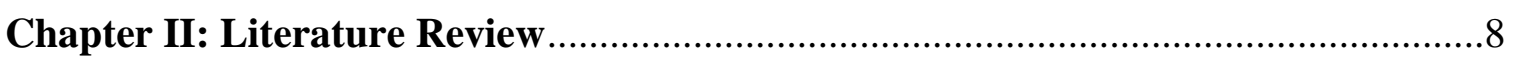

Adolescent Development of Food Preferences .......................................................8

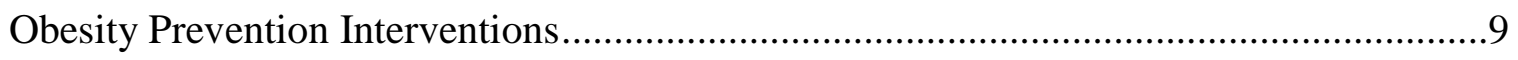

Obesity Prevention Interventions for the Traditional School Hours .............................10

Obesity Prevention for the Afterschool Hours.......................................................12

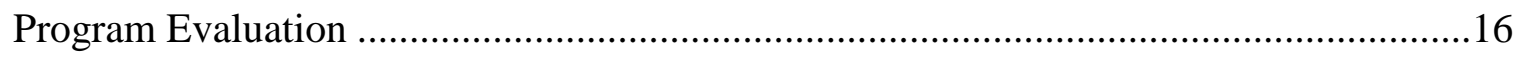

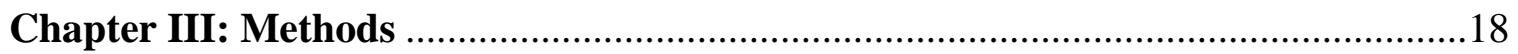

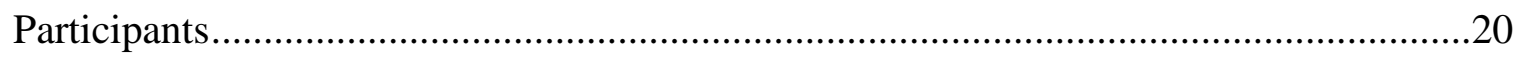

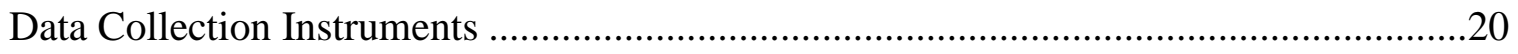

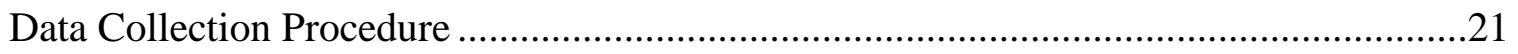

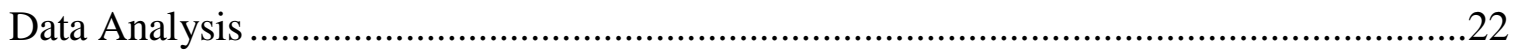

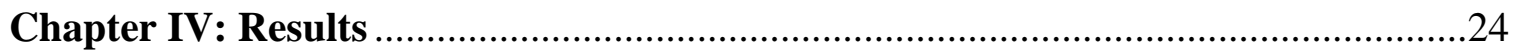

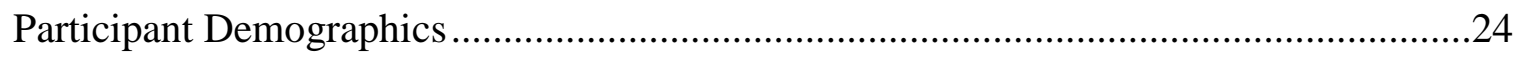

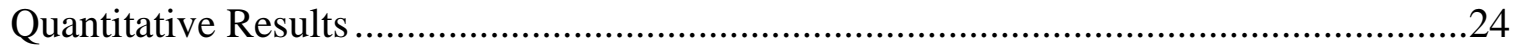




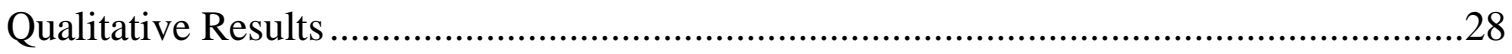

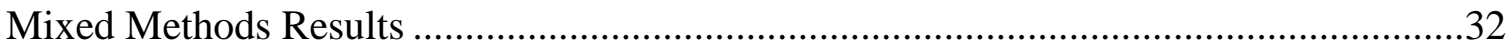

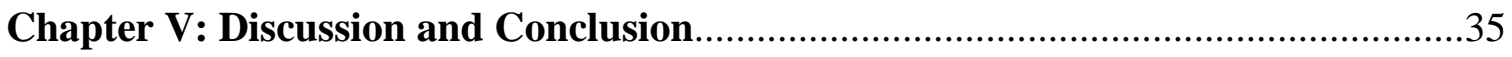

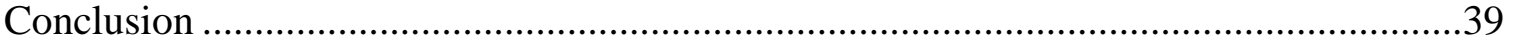

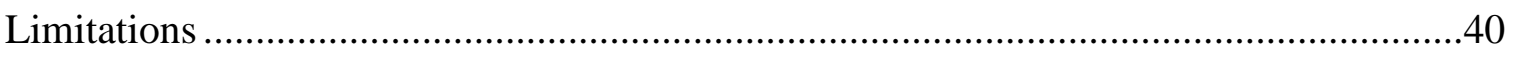

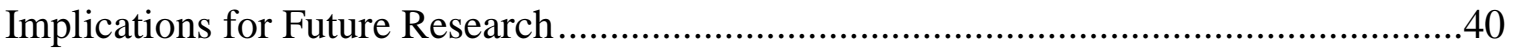

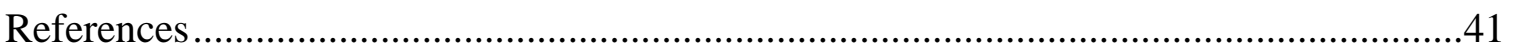

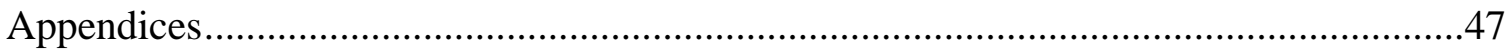




\section{List of Figures}

1. Explanatory Design: Follow-up Explanations Model (QUAL Emphasized) 19

\section{List of Tables}

1. KidQuest Intervention Components .........................................................

2. Demographic Characteristics of Survey and Focus Group/Structured Interview Participants.

3. Quantitative Results, Descriptive Statistics

4. Qualitative Theme Summary and Evidence From Participant Quotations

5. Side-by-side Comparison of Qualitative Themes and Quantitative Results with Mixed Methods Interpretation and Implications 


\section{List of Appendices}

Appendix A. IRB Letter of Approval - KidQuest Program Delivery ..............................48

Appendix B. IRB Letter of Approval - Protocol Change (Focus Group) ........................51

Appendix C. IRB Letter of Approval - Protocol Change (Modified Baseline Survey ......54

Appendix D. Lincoln Public Schools, Letter of Approval...........................................57

Appendix E. IRB Approved Parental Informed Consent, Curriculum, and Surveys ........59

Appendix F. IRB Approved Youth Informed Assent, Curriculum, and Surveys ............62

Appendix G. IRB Approved Recruitment Form, Focus Group ...................................64

Appendix H. IRB Approved Parental Informed Consent, Focus Group ........................66

Appendix I. IRB Approved Youth Informed Assent, Focus Group .............................69

Appendix J. Youth Baseline Survey (Version 1) ..................................................... 71

Appendix K. Youth Baseline Survey (Version 2) .....................................................77

Appendix L. Youth Follow-Up Survey ............................................................ 81

Appendix M. Focus Groups/Structured Interview Script .......................................85

Appendix N. KidQuest Nutrition Lessons (6 Lessons) .............................................8

Appendix O. KidQuest Family Fun Packs (4 Packs)................................................122 


\section{CHAPTER I}

\section{INTRODUCTION}

Thirty three percent of children and adolescents in the United States are considered overweight or obese. The prevalence of childhood and adolescent obesity has tripled from $7 \%$ to $20 \%$ and $5 \%$ to $18 \%$ in the last 30 years, respectively (Centers for Disease Control and Prevention [CDC], 2013). Overweight and obesity has both short and long term physical and mental health implications. Short term implications include low self-esteem, a negative body image, increased risk for high cholesterol, blood pressure, type two diabetes, asthmatic problems, pre-mature puberty, etc. (Cheng et al., 2012; American Dietetic Association [ADA], 2006). Long term implications include a significantly increased risk of adult obesity, cardiovascular diseases, stroke, cancer, and osteoarthritis (ADA, 2006; CDC, 2011).

A balance of nutrition and physical activity plays a critical role in preventing overweight and obesity and disease risk management. Nutrition also aids in proper growth and development of the body (US Department of Agriculture [USDA] \& US Department of Health and Human Services [HHS], 2010) and cognitive functioning (Erikson, 2006). The 2010 Dietary Guidelines for Americans (USDA \& HHS, 2010) recommend that adolescents ages 11 to 14 consume approximately 1600 to 2200 kilocalories, 3.5 to 4.5 cups of fruits and vegetables, three cups of dairy, and no more than $2300 \mathrm{mg}$ of sodium per day, respectively. In addition, the guidelines recommend adolescents to reduce the consumption of calories from solid fats and added sugars and to consume water, fat-free milk, $100 \%$ fruit juice, or unsweetened tea or coffee instead of sugar-sweetened beverages and to eat breakfast daily. While these guidelines exist, 
researchers suggest that less than $25 \%$ of adolescents ages 10 to 15 do not meet the recommended daily fruit and vegetable intake and less than $20 \%$ know the recommended number of servings per day (Zapata, Bryant, McDermott \& Hefelfinger, 2008).

Researchers also report that adolescents consume nearly twice as much sugar-sweetened beverages than milk (Forshee, Anderson, \& Storey, 2006), 40\% of their daily calories are from added sugar and solid fats (Reedy \& Krebs-Smith, 2010), and less than 50\% do not eat breakfast daily (Zapata et al., 2008).

According to the 2011 Youth Risk Behavior Surveillance Survey (YRBSS) (2011), two in five adolescents consumed zero servings of milk while over one in ten adolescents consumed more than three sugar-sweetened beverages seven days prior to taking the survey. In Nebraska, two in five adolescents did not consume any servings of fruit and nearly $75 \%$ consumed less than two servings of vegetables the week prior to taking the survey (YRBSS, 2011).

Daily physical activity is important in overweight and obesity prevention because it helps balance calories consumed and calories burned. Physical activity supports disease risk management, bone and muscle health, stress management, and self-esteem (US Department of Health and Human Services [HHS], 2008). The 2008 Physical Activity Guidelines for Americans (HHS, 2008) recommend that children and adolescents participate in 60 minutes or more of daily physical activity including moderate to vigorous activities and bone and muscle strengthening exercises. Moderate to vigorous activity includes activity equivalent to brisk walking or running while muscle-strengthening activity includes push-ups, sit-ups, weights, and/or swinging on monkey bars. Bone-strengthening exercises include running, brisk walking, and jumping. 
As with nutrition, adolescents do not meet the daily physical activity recommendations. The 2011 YRBSS (2011) suggests that nearly 50\% of adolescents met the recommended 60 minutes of physical activity at least 5 days per week while $13.8 \%$ of adolescents did meet the recommended amount on any day of the week. While these statistics indicate that more adolescents are physically active than not active, child and adolescent overweight and obesity remain.

In an attempt to reduce overweight and obesity in early adolescence, current research and interventions focus primarily on children; however, the early adolescent population should not be overlooked. For the purpose of this study, adolescence will be defined as individuals between the ages of 11 and 15. Youth and adolescent development specialists, Russell and Bakken (2002), state that during adolescence, individuals start developing autonomy and the desire for independency.

Many obesity prevention interventions also focus on traditional school hours; however, researchers suggest that afterschool programs have the potential to positively impact adolescents.

According to the Afterschool Alliance (2007), afterschool is defined as a program that occurs before and/or after the traditional school day and commonly on non-school days, such as holidays and summer vacation. Roughly 3.7 million middle school adolescents are left unsupervised during the afterschool hours, $45 \%$ of those from lowincome households. In Nebraska, one in three middle school adolescents are left unsupervised during the afterschool hours (Afterschool Alliance, 2009).

Nearly $90 \%$ of parents with adolescents enrolled in afterschool programs report they are satisfied because it provides a safe environment where adolescents can develop 
social skills as well as participate in organized clubs and activities. Parents also report that afterschool programs help adolescents succeed in school (Afterschool Alliance, 2009).

\section{Significance of Research}

KidQuest, developed by South Dakota Extension, is an effective, pilot-tested, nutrition and physical activity intervention developed specifically for early the early adolescence population ( ages 10 to 12) (Jensen, Kattelmann, Ren, \& Wey, 2009). The intervention, developed for the traditional school day, is based on the Social Cognitive Theory (SCT) to describe how self-control, problem solving and decision making, as well as skills and self-efficacy impact behavior change (Jensen et al., 2009). The program is comprised of six lessons (Appendix $\mathrm{N}$ ) and is designed to be delivered once a month for six months. Each month, participants are given one 20 to 30 minute hands-on nutrition lesson followed by a 10 minute Physical Activity Lessons (PALs) to get the participants moving. Table 1 identifies and describes the KidQuest intervention components.

\section{Table 1 \\ KidQuest Intervention Components}

Nutrition Lessons: Six different 30-40 minute hands on nutrition education activities are provided in the classroom on a 1or 2 times per month basis over the course of 4-6 months during the school year.

\section{Introduction, Label Lingo and Think Your Drink}

- Learn how to read food labels and take the "Sugar Shocker" challenge where they will demonstrate the actual amount of sugar in popular drinks.

2. Eating Out, Portion Sizes, and Snacks

- Demonstrate how they can use the food label and portion sizes as tools when choosing snacks.

- Work in groups and visit mock restaurants. Determine the amount of calories and fat in various menu items.

3. Fruits and Veggies

- Discover the importance of eating a wide variety of fruits and veggies from different color sources.

- Play Fruit and Veggie ball toss while learning about the health benefits of fruits and vegetables. 
(Table 1 Continued)

4. Whole Grains and Breakfast

- Learn about the benefits of breakfast and come up with solutions to common skipping breakfast excuses.

- Work in teams to complete: "name that grain", "breakfast choices", "think tank", and "is it a whole grain".

\section{Dairy Intake}

- Learn the importance of not robbing their bones as they play a "bone banking" jeopardy game.

6. Media Messages

- Learn about advertising of food products. Determine fact from fiction while teaming up to "sell" a healthy product.

Physical Activity Lessons (PALs): 10-15 minute physical activities are completed each nutrition lesson (i.e. stories on the move, fitness dice, dancing, and scarf catch). Physical activity benefits with practical and fun tips are provided. Additional physical activities will be incorporated into the daily classroom routine. Family Fun Fitness nights are also an option provided to schools.

Quest Challenges: Participants pick 1 of the 8 challenges to work on at home between nutrition lessons. The challenge choices correspond to the nutrition lessons and include physical activities. KidQuest Bucks are awarded for attempting a challenge and turning in a challenge calendar with extra bucks awarded for discussing the challenge with the participant's parent. Health and physical activity related rewards can be purchased with KidQuest Bucks at the completion of the program.

Parent Newsletters: Provided four times during the program covering topics presented in the nutrition lessons.

Family Fun Packs: Four different Family Fun Packs (Snacks, Family Mealtimes, Family Fitness, and Screen Time) are available for participants to take home. Each pack contains: tip cards, recipes, small promotional items, participant feedback card and Quest family challenge. A variety of wellness related incentive items are available for selection after completion.

In 2005, the KidQuest intervention was piloted in rural South Dakota and continues today. Adolescents who participated in the pilot program reported significant improvements in dietary intake, increased frequency of breakfast consumption, and increased knowledge and application of using a food label. Adolescents who participated in the control group reported no significant change (Jensen et al., 2009).

Researchers recognize that implementing obesity prevention interventions in the afterschool setting have great potential in reducing the issue of childhood obesity; however, there is little research to support this theory or hypothesis. Afterschool 
programs present a great opportunity to promote and educate nutrition and physical activity due to the time of day, the developmental age of adolescents, and the safe environment (USDA, 2006). Further research is needed to provide effective obesity prevention interventions in the afterschool setting. In an attempt to fill this literature gap, the University of Nebraska-Lincoln conducted a pilot study to evaluate the effectiveness of implementing KidQuest in an afterschool program.

\section{Propose}

The purpose of this pilot study was to evaluate the effectiveness of using a nutrition and physical activity intervention (KidQuest) developed for the traditional school day in an afterschool setting. The desired outcome was for participants to use nutrition related knowledge and skills learned to increase self-efficacy and change behavior.

\section{Hypothesis}

The researchers hypothesized that following the KidQuest intervention, participants would use nutrition related knowledge and skills learned to increase selfefficacy and change behavior.

\section{Objectives}

1. To measure knowledge gained from a middle school afterschool nutrition program through the use of a pre/post youth survey.

2. To confirm participant learning experiences from a middle school afterschool nutrition program through the use of focus groups/structured interviews. 
3. To formulate a comparison between a pre/post youth survey and focus groups/structured interviews to evaluate a middle school afterschool nutrition program. 
CHAPTER II

\section{LITERATURE REVIEW}

\section{Adolescent Development of Food Preferences}

Story, Neumark-Sztainer, and French (2002) suggests that many factors influence adolescent development of food preference including: intrapersonal (individual influences), interpersonal (social environmental influences), community environment (physical environment), and macrosystems (societal influence). Intrapersonal influences include food preferences and taste which are developed from childbirth, self-efficacy, and the knowledge of why and what food should be consumed. Lifestyle, which involves available time and the convenience of food, is another intrapersonal factor that has one of the strongest influences on food preferences.

Interpersonal influences include family and family meals, demographics, food availability, and peers. While one may believe that peers are most influential in determining adolescent food preferences, Story et al. (2002) reports that family and family meals are. The community or physical environment is another influential factor in the development of food preferences as it dictates where adolescents get their food. Examples include: schools, afterschool programs, fast-food restaurants, vending machines, and convenience stores. The last factor, the macrosystem or societal influence, includes media and advertising, social and cultural norms of food and beverages consumed, as well as policies and laws that impact availability and pricing of food (Story et al., 2002). 


\section{Obesity Prevention Interventions}

According to the Academy of Nutrition and Dietetics (ADA) (2006) and other researchers, effective obesity interventions must include a nutrition and physical activity component. Interventions must state clear objectives, include multiple components, be age appropriate, include activities to engage the target population, and promote family involvement (Kropski, Keckley, \& Jenson, 2008; DeBar et al., 2012; American Youth Policy Forum [AYPF], 2006; Hoelscher, Evans, Parcel, \& Kelder, 2002; Bayne-Smith et al., 2004; Gonzalez-Suarez, Worley, Grimmer-Somers, \& Dones, 2009; ADA, 2010). Effective interventions should be designed to promote behavior change which may be achieved through use of Social Cognitive Theory (SCT) in program development (ADA, 2006; Contento, 2011, p. 95).

The SCT describes how health behaviors are influenced by personal, behavioral, and environmental factors. Within these factors, Glanz, Rimer, \& Viswanath (2008) describe major concepts and implications for intervention including: environment, behavioral capability, expectations, expectancies, self-control, observational learning, reinforcements, self-efficacy, emotional coping responses, and reciprocal determination.

The environment is what physically surrounds a person and what provides opportunities and social support, while the situation is how the person perceives the environment. Behavioral capability includes the knowledge and skills learned through a training or intervention. Expectations include the anticipated outcomes of a behavior while expectancies include the value that one gives to outcomes of the expectations. Self-control is the outcome of making a decision, setting goals, and solving problems. Observational learning is when an individual observes one's behavior, decisions, and 
reinforcements enforced upon the decisions. Reinforcements and self-efficacy impact an individual's behavior and decisions because when rules and regulations are reinforced, there is higher self-efficacy to follow the reinforcement. Emotional coping responses explain how one deals with decisions made which are based on the concepts identified. Reciprocal determinism explains how all the influences identified impacts behavior while considering the relationship between the person, behavior, and environment (Glanz et al., 2008).

\section{Obesity Prevention Interventions during Traditional School Hours}

In 2012, the Institute of Medicine (IOM) (2012) published an article that identified the traditional school day as one of five focus areas for accelerating obesity interventions due to the foundation of health and physical education (Shaya, Flores, Gbarayer \& Wang, 2008). As a result, the majority of obesity interventions are designed for the traditional school day (Della Torre, Akré, \& Suris, 2010). However, the core

academic classes identified by the US Department of Education (2009) include English, reading or language arts, math, science, foreign languages, civics and government, economics, arts, history, and geography. Two subjects that do not appear on the list include health and physical education. While the education of adolescents on the core classes is the primary concern for school teachers and administrators, time is needed to educate students on health and physical education.

Not all schools offer health and physical education to each grade level. According to the National Association of State Boards of Education (NASBE) (2012) nutrition education, which is often included in health education, is not required in 
Louisiana, Michigan, Missouri, and Oklahoma. Ironically, each of these states appear in the top 10 obese states in the United States (CDC, 2011).

Every state and local school district has their own standards for health and nutrition education. Approximately $46 \%$ of states require health education which includes nutrition related topics; while the other $54 \%$ have either no requirements or are only encouraged to follow research-based standards (NASBE, 2012).

Researchers report that some school teachers and administrators understand the importance of proper nutrition for adequate cognitive functioning of students. Wiecha and colleagues (2012) conducted a focus group study with school teachers within14 schools. Some of the school teacher participants reported that they voluntarily integrate health, nutrition, and physical education into their classroom curriculum; however, there is often a lack of knowledge, application, and incentive to do so (NASBE, 2012). Another study analyzed focus groups with school administrators, physical education (PE) staff, food staff, adolescents, and parents of adolescents. School administrators and staff reported a lack of guidelines, while all participants indicated they did not have a clear understanding of why obesity prevention interventions were important (Della Torre, et al., 2010).

In 1996, 64\% of all schools were required to provide nutrition education which was taught by classroom teachers $(61 \%)$ or coordinators with nutrition training. While $90 \%$ of the curriculum was provided through the school meal program, the quality of the education is unknown. The subject matter within the curriculum often included: relationship between diet and health, how to find and choose healthy foods, nutrients and sources, the Food Guide Pyramid, and the Dietary Guidelines and goals (CDC, 1996). 
More recently, schools are encouraged to create written policies for nutrition and physical activity to include in an overarching school wellness policy. Examples of these policies include healthy food options in cafeteria, no vending machines or a limit on the time of operation, and food choices at school health events. While these policies decrease the access to sugar-sweetened beverages and high fat, high sodium foods, researchers report the need for an educational component (Della Torre et al., 2010).

As with nutrition, physical education (PE) requirements differ between states and local districts. In 2008, $49 \%$ of states required PE in kindergarten through $12^{\text {th }}$ grade which was commonly taught by certified, licensed, or endorsed teachers (Kann, Brener, \& Wechsler, 2007). In US middle schools, 84\% have PE built into the school curriculum. While this number appears high, only $8 \%$ of middle schools provide daily PE throughout the school year (Lee, Burgeson, Fulton, \& Spain, 2006; Kann et al., 2007; CDC, 2011, HHS, 2006). Physical education is a critical part of the school curriculum because $62 \%$ of adolescents do not participate in physical activity outside of the traditional school day (CDC, 2003). While researchers in the US report that increasing PE by just one hour may have a positive impact on BMI, the Institute of Medicine (2012) suggests there is a lack of time and money to increase physical activity opportunities in the traditional school day (Datar \& Sturm, 2004; Institute of Medicine [IOM], 2012, p. $337-340)$.

\section{Obesity Prevention during the Afterschool Hours}

Each year, over 1.4 million middle school adolescents participate in afterschool programming, while 3.7 million care for themselves (Afterschool Alliance, 2009). According to the Afterschool Alliance (2009), adolescents spend more than 15 hours 
each week in afterschool programs. While some programs focus on academics, others focus on engaging youth in interactive clubs based on the interests of the adolescents such as art, tennis, and robotics club (AYPF, 2006).

In 2011, the National Afterschool Association developed Healthy Eating and Physical Activity (HEPA) Standards (Wiecha et al., 2011). The guidelines address six items for healthy eating: (1) Content and quality which addresses recommendations for foods to serve/not serve, portion sizes, accommodations for food allergies and suggestions for the use of non-evidence-based curriculums and those that promote a specific product or are for-profit; (2) Staff training which addresses the use of qualified individuals for training delivery and regular health promotion awareness training and coaching; (3) Nutrition education curriculum which identifies suggested research-based programs; (4) Social support which addresses the importance of promoting a healthy environment encompassing food, active adolescent participation, staff, and parent engagement; (5) Program support which addresses program evaluation, food budgets, federal programs, and the importance staff role modeling; and (6) Environmental support which addresses the use of nutrition related posters, books, games, and activities as well as the importance of adequate kitchen and storage facilities.

The HEPA guidelines also address five items for physical activity: (1) Content and quality which addresses types of activities to promote/not promote; (2) Staff training which addresses the importance professional development, participation of all adolescents including those with disabilities, and the importance of not withholding activities for anyone; (3) Social support which addresses the importance of staff, adolescent, and parental involvement, (4) Program support which addresses budgets and 
program evaluation; and (5) Environmental support which addresses appropriateness and adequacy of equipment and indoor/outdoor facilities (Wiecha et al., 2011).

While these guidelines exist, many afterschool programs are not aware of the guidelines. However, when asked in focus group sessions, afterschool program directors reported that they understand the importance of nutrition and physical activity, but identified many barriers to promoting a healthy environment (Wiecha, Hall, Gannett \& Roth, 2012). Dennehey, Gannet, and Robbins (2006) reported a lack of staff knowledge and training for afterschool programs which contributed to a large scope of staff educational levels and training backgrounds. In addition, afterschool programs face high turnover rates due to staff who frequently use the position as a transitional job to another career path. Afterschool staff positions have little possibility for advancement and are generally paid close to minimum wage. Gannett, Mello, and Starr (2009) suggest that diverse education and training coupled with high turnover rates presents an environment where staff may not understand the importance of providing a healthy environment.

Another barrier to promoting a healthy environment involves the availability of food and equipment as well as the knowledge and skills related to food planning and preparation. Often times snacks that are provided during afterschool programs are funded entirely or partially by a state or federal agency, such as the United States Department of Agriculture's (USDA) Child and Adult Food Program (CACFP) or Afterschool Snack Program (Wiecha et al., 2012). When funded by the CACFP, schools are reimbursed through cash payments and/or food items provided by the USDA. The centers who receive cash funding are required to purchase and provide two of the following snack items: fluid milk, meat or meat alternative, fruit or vegetable juice, or 
grains or breads (USDA). Afterschool programs that purchase their own snacks likely do not have a nutrition background. Therefore, high calorie, low nutrient granola bars, crackers, and sugar-sweetened beverages are frequently purchased because of the convenience and low cost. Other funding agencies provide food items such as fresh produce. While this is a healthy snack, many afterschool programs who receive food items do not have access to kitchens to wash or store fresh produce (Wiecha et al., 2012; USDA).

Another barrier to promoting a healthy environment in the afterschool setting, identified by the Academy of Nutrition and Dietetics (ADA, 2006), is the lack of obesity prevention interventions offered in the afterschool setting. This gap must be filled as researchers suggest that afterschool programs offer a more effective environment than the traditional school day as evidenced by the potential benefits identified in adolescents who participate in afterschool programs (Kahne et al., 2001). Elkins, Cohen, Koralewicz and Taylor (2004) reported that adolescents who participate in afterschool programming have lower body mass indexes (BMI) and rates of overweight and obesity than their counterparts. Other researchers attribute this to increased time spent being physically active, decreased time spent eating, and decreased time spent being sedentary in afterschool programs compared to individuals not enrolled in an afterschool program (Mahoney, Lord, \& Carryl, 2005).

Researchers also suggest that participation in afterschool programs may positively impact an adolescent's social and emotional wellbeing. The Harvard Family Research Project states that afterschool programs help to improve relationships, increase selfconfidence/esteem/efficacy, improve feelings and attitudes toward self and school, as 
well as decrease levels of depression/anxiety and behavioral problems (Little, Wimer, \& Weiss, 2008).

The Afterschool Alliance (2009) reports 3.7 million adolescents are left unsupervised during the afterschool hours. Adolescents who are left unsupervised are more likely to participate in "risky behaviors" such as crime, drug use, and sexual relationships than adolescents enrolled in afterschool programs (Cross, Gottfredson, Willson, Rorie, \& Connell, 2009). Researchers have also reported that adolescents who participate in afterschool programming have increased peer-acceptance, higher school attendance, and improved grades and test scores (Mahoney, et al., 2005, Durlak, Weissberg, \& Pachan, 2010; Afterschool Alliance, 2007; US Department of Justice [USDJ], 2001).

\section{Program Evaluation}

Contento (2011, pp. 320-335) recommends investigators designing a theory-based nutrition program follow a six-step process which includes program evaluation. While program evaluation is the last step in designing a theory-based nutrition education program, evaluation is critical because it identifies the effectiveness of the program and whether the outcomes were achieved.

Program evaluation is important in both research and practice-based settings. In a research setting, program evaluation helps identify the effectiveness of a program and what worked and what didn't work. Evaluation helps researchers provide recommendations for future research. In a practice-based setting, program evaluation helps identify if goals and objectives are met, and the appropriateness of the intervention 
(Contento, 2011, pp. 320-335). A well-designed program evaluation justifies a need for intervention and further research (Kropski, et al., 2008).

To evaluate an intervention, one must select the appropriate type of assessment and tools to measure outcomes. In obesity prevention interventions, the investigators often collect quantitative data which includes anthropometric measurements, surveys, and questionnaires (Contento, 2011, p. 327). Quantitative data are analyzed using statistics and involves identifying trends, comparing groups, and relating variables (Plano Clark \& Creswell, 2010, p. 69-72). This type of evaluation is important for researchers and practitioners working with grant funding because numerical results illustrate direct impacts (Creswell, 2009, pp. 151-152).

Another type of data used by investigators to evaluate obesity prevention interventions includes qualitative data. Examples of qualitative data include interviews, focus groups, and observations (Contento, 2011, p. 327). Qualitative data are often analyzed using word analysis and involves identifying themes and interpreting descriptions (Plano Clark \& Creswell, 2010, p. 69-72). While quantitative evaluation methods are more commonly used, qualitative evaluation methods are becoming more accepted in the field of research.

Sometimes investigators utilize both quantitative and qualitative data to evaluate a program which is known as a mixed methods approach. Both types of data are collected, analyzed, and provide further insight to the findings by comparing the two data sets (Creswell, 2009, p. 4). Creswell and Plano Clark (2007, p. 13) suggest that using a mixed methods approach in program evaluation provides a more complete evaluation or analysis because of the use of multiple evaluation tools. 


\section{CHAPTER III}

\section{METHODS}

For this pilot study, the KidQuest curriculum was modified to accommodate the needs and desires of the afterschool program. The nutrition lessons (Appendix N) were delivered accordingly, while the parent newsletters and Family Fun Packs (Appendix O) were offered. The Physical Activity Lessons (PALs) (Table 1) were modified to promote participation and to meet the needs of the afterschool program. The physical activity time included the following games: relay races, dice game, kickball, human bowling, and open gym (volleyball and basketball). The Quest Challenges (Table 1) were not implemented in this pilot study. A food preperation component was added after it was requested from an afterschool program director and is evaluated in a different study.

A mixed-methods approach with explanatory design (Figure 1) was used to collect qualitative data following quantitative data to evaluate KidQuest (Creswell \& Plano Clark, 2007, pp. 71-75). At baseline and follow-up, participants were asked to complete a youth survey, a self-image survey, and to participate in a physical assessment and fitness assessment. Parents of the participants were also encouraged to complete and return a survey at baseline and follow-up. For the purpose of this study, only the youth baseline and follow-up surveys were analyzed. Upon completion of the intervention, program participants were encouraged to participate in a voluntary focus group.

The youth baseline survey (Appendices J-K) was distributed to identify knowledge and behavior about nutrition and physical activity prior to the intervention. The KidQuest program was then delivered within one school quarter or six weeks, respectively. Following the intervention, a youth follow-up survey (Appendices L) was 
delivered to identify change in knowledge or behavior. Lastly, a focus group/structured interview (Appendix M) session was conducted to gain further insight on knowledge or behavior change identified in the quantitative assessment.

Participants were required to sign an informed assent (Appendix F) and were required to obtain informed parental consent (Appendix E) for participation in the data collection. The focus group/structured interview sessions required a separate assent (Appendix I) and consent (Appendix H) which was collected prior to the session.

The KidQuest study and focus groups/structured interview was approved by the University of Nebraska-Lincoln Institutional Review Board (IRB) (Appendices A-C). Approval was also granted from the Lincoln Public School System (Appendix D).

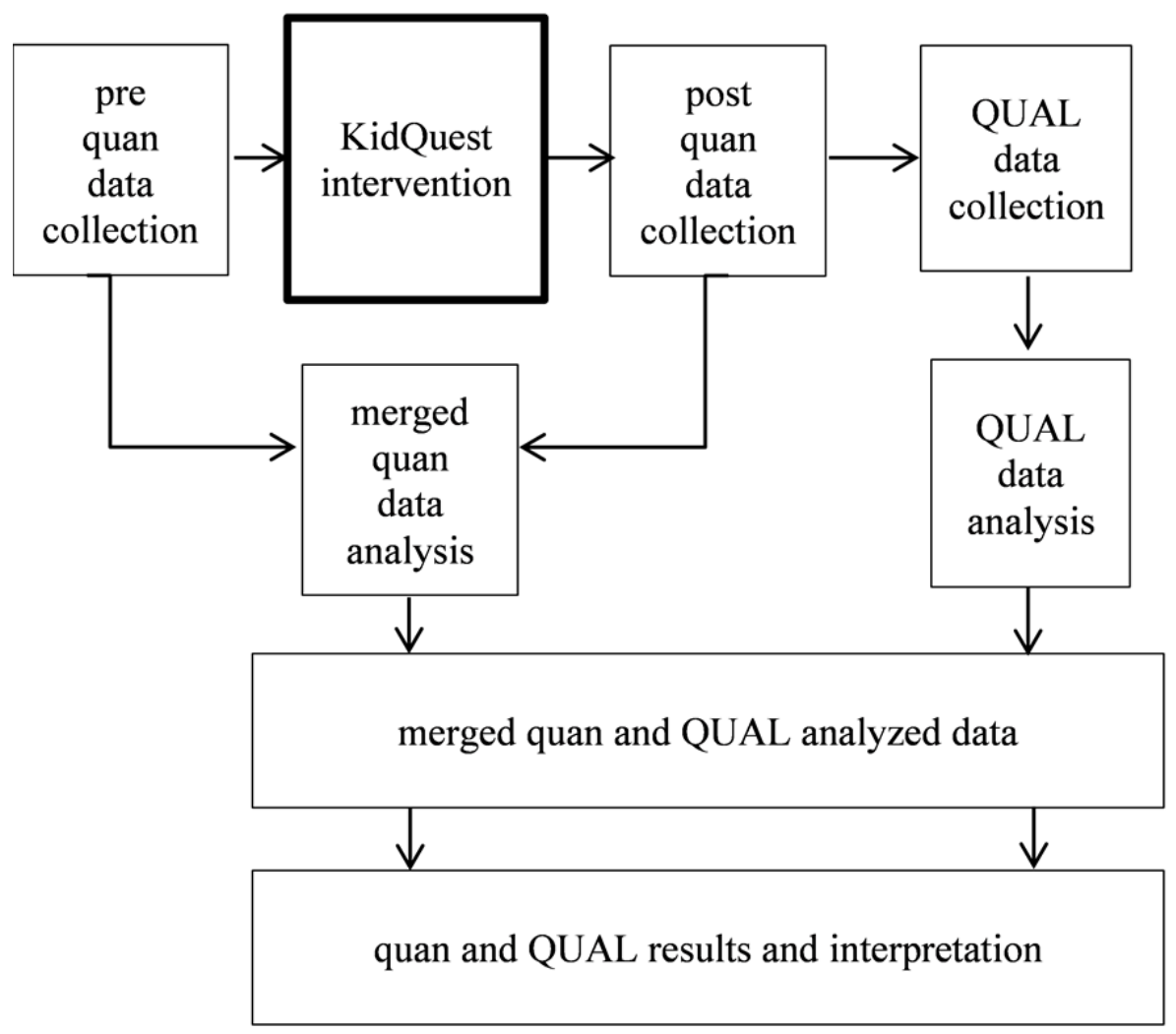

Figure 1. Explanatory Design: Follow-up Explanations Model (QUAL emphasized) *Modified from Creswell \& Plano Clark, 2007. 


\section{Participants}

Convenience sampling was used with the help of afterschool program directors and afterschool program staff to recruit participants for the KidQuest program. All adolescents interested in KidQuest were able to participate in the intervention; however, only those with signed parental informed consent and youth assent were able to participate in the data collection. All participants were encouraged to participate in a focus groups/structured interview session that occurred after the intervention. A $\$ 15.00$ gift card incentive was provided to participants who completed all surveys and assessments at baseline and follow-up. Small incentives, such as T-shirts, were offered to the focus group/structured interview participants.

\section{Data Collection Instruments}

\section{Quantitative Data}

The youth baseline and follow-up surveys (Appendices J-L) were modified from the original KidQuest surveys developed at South Dakota State University. These surveys were tested for reliability using retest methods (5\% of the variables had reliabilities of 0.70 and higher, $11 \%$ at $0.58-0.69$, and $4 \%$ (only 1 variable - small soft drink when eating out reliability indicator of 0.4) at less than 0.50) (Jensen et al., 2009). Modifications were made to shorten the survey length and to ensure the University of Nebraska-Lincoln outcomes were measured. Modifications included question removal to shorten the survey length and slight word modification to three questions. Five questions were added from surveys used in the National Education Program and Building Healthy Families which were previously tested for validity and reliability. The highlighted questions on the survey indicate those analyzed for this study (Appendices J-L). 


\section{Qualitative Data}

The purpose of the focus groups/structured interview was to gain participant perspectives on the KidQuest intervention and to further investigate self-efficacy and behavior change from knowledge and skills learned. The focus group script and open ended questions (Appendix M) were designed using a modified process described by Krueger and Casey (2009, pp. 52-61). Estimated time for question delivery and participant response was considered. An evaluation specialist provided suggestions and modifications were made accordingly.

\section{Data Collection Procedures}

\section{Quantitative Data}

The youth baseline and follow-up surveys (Appendices J-L) were collected before the KidQuest intervention (Appendix N-O) began and at the end of the intervention. Due to survey modifications, two versions of the youth baseline survey were collected (Appendix J-K). Adolescents were informed that participation was voluntary and that there were no known risks associated with participation. Parental informed consent (Appendix H) and youth assent (Appendix I) were distributed and returned to the Primary Investigator. Only participants with informed consent and assent were used in this study. Baseline and follow-up surveys were identified using a participant identification number. The baseline surveys were collected by UNL graduate assistants prior to the intervention and follow-up surveys were collected post intervention. Version one of the youth baseline survey (Appendices J) was collected at school A while version two (final version) (Appendix K) was collected at schools B and C. All schools received the same youth follow-up survey (Appendix L). Upon completion of the intervention and follow- 
up survey, participants were thanked for their participation and were able to ask questions they had about their participation in the study.

\section{Qualitative Data}

Focus groups (Appendix M) were conducted after all of the post assessments were collected. Only participants who returned a signed parental informed consent and youth assent prior to the focus group were allowed to participate. The focus group moderator facilitated the one hour sessions while one research assistant who taught the program documented abbreviated responses from the participants. Sessions were audio recorded to reference and help recall accuracy of information. To protect participant identities, identifiable information was not recorded on audio tape nor transcribed from the written notes. After completion of the sessions, participants were thanked for their participation and given an incentive.

\section{Data Analysis}

\section{Quantitative Data}

Data from the youth baseline and follow-up surveys were entered into Qualtrics, an online survey software, using double data entry and then uploaded into the SPSS Program Version 21. A total of 14 questions were analyzed using descriptive statistics due to the survey modifications and small sample size $(n=18)$. The mean responses from the survey questions at baseline and follow-up were compared using a paired t-test. The Nebraska Evaluation and Research Center (NEAR) at the University of Nebraska-Lincoln was consulted to ensure accurate data analysis. 


\section{Qualitative Data}

Qualitative data were analyzed using the steps identified by Creswell (2009, 185193). The focus groups/structured interview (3 groups, 6 participants) were transcribed verbatim from the audio-recorded sessions. After compiling the transcripts, the data were read to obtain a "general sense" of the data and to omit verbal pauses, such as "ahs" and "umms". Next, transcripts were coded and themes were generated. To ensure validity, three researchers identified themes independently and met to compare and develop the final themes (Plano-Clark \& Creswell, 2010, p. 287).

\section{Mixed Methods Data}

After the quantitative and qualitative data were analyzed independently, the data were merged and analyzed collectively. Merging the two data sets allowed for a more complete evaluation of KidQuest. Major themes were used to verify the quantitative findings. Validity, defined as the ability to draw meaningful and accurate conclusions from both the quantitative and qualitative data (Creswell and Plano Clark, 2007), was considered in the mixed methods analysis. 


\section{CHAPTER IV}

\section{RESULTS}

\section{Participant Demographics}

A total of eight youth baseline and ten follow-up surveys were analyzed for this study (Table 2). A total of six participants participated in the focus groups/structured interview sessions (Table 2).

\begin{tabular}{|c|c|c|c|c|c|c|c|c|c|c|c|c|}
\hline \multicolumn{13}{|l|}{$\begin{array}{l}\text { Table } 2 \\
\text { Demogral }\end{array}$} \\
\hline Gender & $\begin{array}{c}\text { Male } \\
\mathrm{n}=2 \\
(25 \%) \\
\end{array}$ & \multicolumn{2}{|c|}{$\begin{array}{c}\text { Female } \\
\mathrm{n}=6 \\
(75 \%)\end{array}$} & $\begin{array}{c}\text { Male } \\
\mathrm{n}=1 \\
(10 \%) \\
\end{array}$ & \multicolumn{2}{|c|}{$\begin{array}{c}\begin{array}{c}\text { Female } \\
\mathrm{n}=8 \\
(80 \%)\end{array}\end{array}$} & $\begin{array}{c}\text { Male } \\
\mathrm{n}=1 \\
(14 \%) \\
\end{array}$ & \multicolumn{2}{|c|}{$\begin{array}{c}\text { Female } \\
\mathrm{n}=5 \\
(86 \%)\end{array}$} & $\begin{array}{c}\text { Male } \\
\mathrm{n}=4 \\
(17 \%) \\
\end{array}$ & \multicolumn{2}{|c|}{$\begin{array}{c}\text { Female } \\
n=19 \\
(79 \%) \\
\end{array}$} \\
\hline $\begin{array}{c}\text { Age } \\
\text { (years) }\end{array}$ & \multicolumn{3}{|c|}{ Mean $=12.40$} & \multicolumn{3}{|c|}{ Mean $=11.98$} & \multicolumn{3}{|c|}{ Mean $=12.14$} & \multicolumn{3}{|c|}{ Mean $=12.17$} \\
\hline $\begin{array}{l}\text { Grade } \\
\text { Level* }\end{array}$ & $\begin{array}{l}6^{\text {th }} \\
7^{\text {th }} \\
8^{\text {th }}\end{array}$ & \multicolumn{2}{|c|}{$\begin{array}{l}1(12.5 \%) \\
2(25 \%) \\
1(12.5 \%)\end{array}$} & $\begin{array}{l}6^{\text {th }} \\
7^{\text {th }} \\
8^{\text {th }} \\
\end{array}$ & \multicolumn{2}{|c|}{$\begin{array}{l}0(0 \%) \\
5(50 \%) \\
1(10 \%)\end{array}$} & $\begin{array}{l}6^{\text {th }} \\
7^{\text {th }} \\
8^{\text {th }} \\
\end{array}$ & $\begin{array}{l}2(3 \\
3(5 \\
1(1 \\
\end{array}$ & $\begin{array}{l}\% \text { ) } \\
\%) \\
\%)\end{array}$ & $\begin{array}{l}6^{\text {th }} \\
7^{\text {th }} \\
8^{\text {th }} \\
\end{array}$ & \multicolumn{2}{|c|}{$\begin{array}{l}4(17 \%) \\
11(46 \%) \\
3(12.5 \%)\end{array}$} \\
\hline $\begin{array}{l}\text { Race / } \\
\text { Ethnicity } \\
\text { (Check } \\
\text { all that } \\
\text { apply) }\end{array}$ & \multicolumn{2}{|c|}{$\begin{array}{l}\text { African- } \\
\quad \text { American } \\
\text { Hispanic } \\
\text { Asian } \\
\text { 2+ Races }\end{array}$} & $\begin{array}{l}1 \\
1 \\
1\end{array}$ & \multicolumn{2}{|c|}{$\begin{array}{l}\quad \text { American } \\
\text { Hispanic } \\
\text { Asian } \\
\text { 2+ Races }\end{array}$} & $\begin{array}{l}8 \\
1 \\
1 \\
2 \\
1\end{array}$ & \multicolumn{2}{|c|}{$\begin{array}{l}\text { African- } \\
\quad \text { American } \\
\text { Hispanic } \\
\text { Asian } \\
\text { 2+ Races }\end{array}$} & $\begin{array}{l}1 \\
1 \\
1\end{array}$ & \multicolumn{2}{|c|}{$\begin{array}{l}\text { African- } \\
\quad \text { American } \\
\text { Hispanic } \\
\text { Asian } \\
\text { 2+ Races }\end{array}$} & $\begin{array}{l}3 \\
4 \\
2\end{array}$ \\
\hline
\end{tabular}

\section{Quantitative Results}

The 14 questions that were analyzed were categorized into the following seven classifications: (1) Nutrition related questions, (2) Knowledge-based questions, (3) Breakfast, (4) Nutrition facts label, (5) Physical activity, (6) Cooking with family, and (7) Weight perception. Table 3 provides descriptive statistics and mean percentages comparing participant responses at baseline and follow-up. Participants reported a slight increase in the number of fruits, vegetables, and whole grains consumed and a slight 
decrease in the number of sugar-sweetened beverages consumed. Participants also reported a slight increase in the consumption of French fries, chips, candy, and desserts. A decrease in knowledge on how to read a food label and an increase in the recommended number of servings of fruits and vegetables was found. Participants reported a slight decrease in breakfast consumption per week. Participants also reported using the nutrition food label more often per week after the intervention. While participants reported nearly no change in physical activity with adult members of the household, they reported a decrease in the frequency of meal planning and cooking from baseline to follow-up. Lastly, participants reported a slight shift from perceiving their weight as about right to overweight.

Table 3

Quantitative Results, Descriptive Statistics

\begin{tabular}{|c|c|c|}
\hline Question & $\underset{n=8}{\text { Baseline }}$ & $\begin{array}{c}\text { Follow-Up } \\
n=10\end{array}$ \\
\hline \multicolumn{3}{|c|}{ NUTRTITION RELATED QUESTIONS } \\
\hline \multicolumn{3}{|c|}{$\begin{array}{l}\text { 1. Yesterday, how many times did you eat fresh, frozen, dried, or } \\
\text { canned fruit? }\end{array}$} \\
\hline None & $1(12.5 \%)$ & $0(0 \%)$ \\
\hline 1 time & $4(50 \%)$ & $4(40 \%)$ \\
\hline 2 times & $0(0 \%)$ & $5(50 \%)$ \\
\hline 3 or more times & $3(37.5 \%)$ & $1(10 \%)$ \\
\hline \multicolumn{3}{|c|}{$\begin{array}{l}\text { 2. Yesterday, how many times did you eat fresh, frozen, or canned } \\
\text { vegetables? }\end{array}$} \\
\hline None & $1(12.5 \%)$ & $0(0 \%)$ \\
\hline 1 time & $3(37.5 \%)$ & $5(50 \%)$ \\
\hline 2 times & $4(50 \%)$ & $4(40 \%)$ \\
\hline 3 or more times & $0(0 \%)$ & $1(10 \%)$ \\
\hline \multicolumn{3}{|c|}{$\begin{array}{l}\text { 3. Yesterday, how many times did you eat whole grain cereal, whole } \\
\text { grain bread, or whole grain crackers? }\end{array}$} \\
\hline None & $2(25 \%)$ & $2(20 \%)$ \\
\hline 1 time & $1(12.5 \%)$ & $4(40 \%)$ \\
\hline 2 times & $4(50 \%)$ & $4(40 \%)$ \\
\hline 3 or more times & $1(12.5 \%)$ & $0(0 \%)$ \\
\hline
\end{tabular}




\begin{tabular}{|c|c|c|}
\hline \multicolumn{3}{|c|}{ (Table 3 Continued) } \\
\hline Question & Baseline & Follow-Up \\
\hline \multicolumn{3}{|c|}{$\begin{array}{l}\text { 4. Yesterday, how many times did you drink any regular pop (not diet), } \\
\text { punch, kool-aid, sports drinks, or other fruit-flavored drinks? }\end{array}$} \\
\hline None & $6(75 \%)$ & $3(30 \%)$ \\
\hline 1 time & $1(12.5 \%)$ & $7(70 \%)$ \\
\hline 2 times & $1(12.5 \%)$ & $0(0 \%)$ \\
\hline 3 or more times & $0(0 \%)$ & $0(0 \%)$ \\
\hline \multicolumn{3}{|c|}{ 5. Yesterday, how many times did you eat French fries or chips? } \\
\hline None & $4(50 \%)$ & $4(40 \%)$ \\
\hline 1 time & $3(37.5 \%)$ & $5(50 \%)$ \\
\hline 2 times & $1(12.5 \%)$ & $1(10 \%)$ \\
\hline 3 or more times & $0(0 \%)$ & $0(0 \%)$ \\
\hline \multicolumn{3}{|c|}{$\begin{array}{l}\text { 6. Yesterday, how many times did you eat ice-cream, sweet rolls, } \\
\text { doughnuts, cookies, brownies, pies, cakes, or candy?** }\end{array}$} \\
\hline None & $4(50 \%)$ & $3(30 \%)$ \\
\hline 1 time & $4(50 \%)$ & $5(50 \%)$ \\
\hline 2 times & $0(0 \%)$ & $2(20 \%)$ \\
\hline 3 or more times & $0(0 \%)$ & $0(0 \%)$ \\
\hline \multicolumn{3}{|c|}{ KNOWLEDGE-BASED QUESTIONS } \\
\hline \multicolumn{3}{|c|}{$\begin{array}{l}\text { 7. Look at the amount of fat on each label. Select the food label that } \\
\text { would provide the least amount of fat if you ate the whole package. }\end{array}$} \\
\hline A & $1(12.5 \%)$ & $2(20 \%)$ \\
\hline B & $0(0 \%)$ & $0(0 \%)$ \\
\hline $\mathrm{C}^{*}$ & $7(87.5 \%)$ & $6(60 \%)$ \\
\hline $\mathrm{D}$ & $0(0 \%)$ & $1(10 \%)$ \\
\hline \multicolumn{3}{|c|}{$\begin{array}{l}\text { 8. How many total cups of fruits and vegetables combined should you } \\
\text { eat each day? }\end{array}$} \\
\hline Less than 2 cups & $1(12.5 \%)$ & $0(0 \%)$ \\
\hline At least 2 cups & $4(50 \%)$ & $4(40 \%)$ \\
\hline At least 3 cups & $3(37.5 \%)$ & $2(20 \%)$ \\
\hline At least 4 cups* & $0(0 \%)$ & $4(40 \%)$ \\
\hline I don't know & $0(0 \%)$ & $0(0 \%)$ \\
\hline \multicolumn{3}{|c|}{ BREAKFAST } \\
\hline \multicolumn{3}{|c|}{$\begin{array}{l}\text { 9. In the past week, how many days did you eat breakfast? / How many } \\
\text { times per week do you usually eat breakfast?** }\end{array}$} \\
\hline 0 days & $0(0 \%)$ & $0(0 \%)$ \\
\hline 1 day & $0(0 \%)$ & $0(0 \%)$ \\
\hline 2 days & $0(0 \%)$ & $0(0 \%)$ \\
\hline 3 days & $1(12.5 \%)$ & $0(0 \%)$ \\
\hline 4 days & $0(0 \%)$ & $1(10 \%)$ \\
\hline 5 days & $0(0 \%)$ & $0(0 \%)$ \\
\hline 6 days & $1(12.5 \%)$ & $2(20 \%)$ \\
\hline 7 days & $6(75 \%)$ & $7(70 \%)$ \\
\hline
\end{tabular}




\begin{tabular}{|c|c|c|}
\hline \multicolumn{3}{|l|}{ (Table 3 Continued) } \\
\hline Question & Baseline & Follow-Up \\
\hline \multicolumn{3}{|c|}{ 10. If you skip breakfast, what is the reason you skip breakfast?** } \\
\hline $\begin{array}{l}\text { Does not apply because I do not skip } \\
\text { breakfast }\end{array}$ & $2(25 \%)$ & $0(0 \%)$ \\
\hline No time to eat breakfast & $1(12.5 \%)$ & $2(20 \%)$ \\
\hline Trying to lose weight & $0(0 \%)$ & $0(0 \%)$ \\
\hline I am not hungry at breakfast time & $1(12.5 \%)$ & $0(0 \%)$ \\
\hline No food available to eat & $0(0 \%)$ & $0(0 \%)$ \\
\hline $\begin{array}{l}\text { I do not like food that is available to } \\
\text { eat / nothing to eat }\end{array}$ & $1(12.5 \%)$ & $2(20 \%)$ \\
\hline I don't know & $1(12.5 \%)$ & $0(0 \%)$ \\
\hline Other (specify) & $0(0 \%)$ & $0(0 \%)$ \\
\hline \multicolumn{3}{|c|}{ NUTRITION FACTS LABEL } \\
\hline \multicolumn{3}{|c|}{$\begin{array}{l}\text { 11. In the past week, have you used the Nutrition Facts food label to help } \\
\text { you decide if the food you eat is a healthy choice or a food you } \\
\text { should eat less of? }\end{array}$} \\
\hline Yes & $3(37.5 \%)$ & $5(50 \%)$ \\
\hline No & $3(37.5 \%)$ & $1(10 \%)$ \\
\hline Not sure & $2(25 \%)$ & $3(30 \%)$ \\
\hline \multicolumn{3}{|c|}{ PHYSICAL ACTIVITY } \\
\hline \multicolumn{3}{|c|}{$\begin{array}{l}\text { 12. In the past week, how often have you done physical activity with at } \\
\text { least one other adult member of your household? ** }\end{array}$} \\
\hline None & $3(37.5 \%)$ & $2(20 \%)$ \\
\hline 1 to 2 times & $1(12.5 \%)$ & $4(40 \%)$ \\
\hline 3 to 4 times & $4(50 \%)$ & $3(30 \%)$ \\
\hline 5 times or more & $0(0 \%)$ & $1(10 \%)$ \\
\hline \multicolumn{3}{|c|}{ COOKING WITH FAMILY } \\
\hline \multicolumn{3}{|c|}{$\begin{array}{l}\text { 13. In the past week, how often have you helped plan or cook any meals } \\
\text { for you and/or your family? }\end{array}$} \\
\hline None & $0(0 \%)$ & $3(30 \%)$ \\
\hline 1 to 2 times & $6(75 \%)$ & $3(30 \%)$ \\
\hline 3 to 4 times & $2(25 \%)$ & $3(30 \%)$ \\
\hline 5 times or more & $0(0 \%)$ & $1(10 \%)$ \\
\hline \multicolumn{3}{|c|}{ WEIGHT PERCEPTION } \\
\hline \multicolumn{3}{|c|}{ 14. Which statement best describes your own weight? } \\
\hline Very underweight & $0(0 \%)$ & $0(0 \%)$ \\
\hline About right & $6(75 \%)$ & $6(60 \%)$ \\
\hline Overweight & $2(25 \%)$ & $3(30 \%)$ \\
\hline Obese (very overweight) & $0(0 \%)$ & $0(0 \%)$ \\
\hline
\end{tabular}


(Table 3 Continued)

*Denotes correct answer

** Denotes questions that were modified to best represent both questions Q6: Yesterday, how many times did you eat ice-cream, sweet rolls, doughnuts, cookies, brownies, pies, cakes, or candy?

Q6: Yesterday, how many times did you eat candy?

Q6: Yesterday, how many times did you eat ice-cream, sweet rolls, doughnuts, cookies, brownies, pies, or cakes?

Q9: In the past week, how many days did you eat breakfast?

Q9: How many times per week do you usually eat breakfast?

Q12: In the past week, how often have you done physical activity with at least one other adult member of your household?

Q12: In the past week, how often /did you do physical activity with at least one other adult member of your household?

\section{Qualitative Results}

Two focus groups $(n=5)$ and one interview $(n=1)$ was conducted with three

Lincoln Public Middle Schools, all of which qualified for Supplemental Nutrition

Assistance Program-Education (SNAP-Ed). The themes and supporting questions, identified by three independent researchers, are listed on Table 4 . The five themes include: (1) KidQuest is fun, (2) Knowledge gained, (3) Physical activity time, (4)

Behavior change, and (5) Recommendations for Future KidQuest Programs (Table 4). KidQuest is Fun

While the definition of "fun" is unknown, the participants frequently described the different components of KidQuest as "fun". "It was fun” was identified over ten times within the text relating to the KidQuest curriculum, physical activities, and the Family Fun Packs. One comment was made asking whether the school was having the KidQuest club again. 


\section{Knowledge Gained}

Knowledge was gained by participants as evidenced by their ability to recall lessons and activities taught in the KidQuest curriculum. Participants identified healthy cooking methods, general tips for identifying healthy foods, recommended number of milk servings per day, the high amount of sugar found sugar sweetened beverages, as well as how to determine if a product is whole grain or not. Knowledge gained was categorized as follows: general KidQuest curriculum, fruits and vegetables, milk, whole grains, sugar-sweetened beverages, media messages and advertising, and physical activity.

Physical Activity Time

As indicated by each of the three schools, physical activity time was the participant's favorite component, possibly because the program was held afterschool and the participants needed to move around. When asked what activity was the least favorite, the participants struggled to provide a definitive answer.

\section{Behavior Change}

Three behavior changes were noted by the participants. One behavior change included nutrition intake while the other two included family engagement.

\section{Recommendations for Future KidQuest Programs}

Participants from each of the participating schools identified recommendations for future KidQuest implementation. Recommendations were categorized into nutrition and physical activity as well as Family Fun Packs. As a general consensus, participants would like to see more time for physical activity and less time for the nutrition lessons. 


\begin{tabular}{|c|c|}
\hline Qualitative Theme & Evidence \\
\hline KidQuest is Fun & $\begin{array}{l}\text { When asked what did you think of the KidQuest } \\
\text { Club: } \\
\text { "It [KidQuest] was fun." } \\
\text { "That [games/activities] was fun." } \\
\text { "It [physical activity time] was fun." } \\
\text { "They [Family Fun Packs] were fun." } \\
\text { "I like that it [Family Fun Packs] like got our } \\
\text { family involved in the program." } \\
\text { When asked for any additional questions or } \\
\text { comments: }\end{array}$ \\
\hline Knowledge Gained & $\begin{array}{l}\text { General KidQuest curriculum: } \\
\text { "We learned a lot about nutrition and exercise and } \\
\text { how it's good for you." } \\
\text { "You need to have like more vegetables, fruit... } \\
\text { and need to cut down on the oil and then eating out } \\
\text { you need to like get stuff that's like healthy and not } \\
\text { too like fried food more like oven baked or } \\
\text { broiled." } \\
\text { Fruits and vegetables: } \\
\text { "You should get more vegetables in your diet. And } \\
\text { fruit." } \\
\text { "You should get more of em. And you should have } \\
\text { em each and every day." } \\
\text { "The darker they are the healthier." } \\
\text { Milk: } \\
\text { "You should have.... } 3 \text { cups of milk a day" } \\
\text { "Milk... help your bones grow... and your muscles } \\
\text { to be strong." } \\
\text { "There's different things you can eat with } \\
\text { calcium... that can help you develop strong teeth } \\
\text { and bones." }\end{array}$ \\
\hline
\end{tabular}




\begin{tabular}{|c|c|}
\hline \multicolumn{2}{|c|}{ (Table 4 Continued) } \\
\hline Qualitative Theme & Evidence \\
\hline (Knowledge Gained Continued) & $\begin{array}{l}\text { Whole grains: } \\
\text { "Whole grain is the best and you need whole grain } \\
\text { because that has all the vitamins and nutrition in it } \\
\text { and like white bread is all that tooken out." } \\
\text { "You can look [at the nutrition food label] and like } \\
\text { the first or second or third thing is supposed to be } \\
\text { whole grain and if it's not it's not whole grain." } \\
\text { "Half of your grains should be whole and like } \\
\text { brown rice is better than white rice." } \\
\text { Sugar-sweetened beverages: } \\
\text { "Energy drinks have a lot of sugar." } \\
\text { "We did a pop experiment...Mountain Dew is like } \\
20 \text { [sugar cubes] in like a } 16 \text { ounce can." } \\
\text { "Drinking pop all the time isn't good for you." } \\
\text { "You have to look at the nutrition facts label and } \\
\text { see how much sugar is in there." } \\
\text { Media messages and advertising: } \\
\text { "We should look at the label and not just the } \\
\text { pictures." } \\
\text { "McDonald's isn't very healthy." } \\
\text { Physical activity: } \\
\text { "I learned how you're supposed to have } 60 \text { minutes } \\
\text { of exercise a day or play time." }\end{array}$ \\
\hline Physical Activity Time & $\begin{array}{l}\text { General physical activity time: } \\
\text { "I think the physical activity time was fun and it's } \\
\text { better than the lesson." } \\
\text { When asked which was their favorite activity: } \\
\text { "My favorite one was the one with the cube." } \\
\text { "Kickball." } \\
\text { "Human bowling" } \\
\text { "The pedometers [accelerometers] ...made me run } \\
\text { and do more things cause I wanna get a lot of walks } \\
\text { in." } \\
\text { When asked which was their least favorite activity: } \\
\text { "It's hard [to state her favorite]." }\end{array}$ \\
\hline Behavior Change & $\begin{array}{l}\text { Milk consumption: } \\
\text { "I've actually boosted my milk. I've had four cups } \\
\text { [of milk] each day. I only had like one or two but } \\
\text { now I have more." } \\
\text { Family engagement: } \\
\text { "We [family] only go out to eat like maybe once a } \\
\text { week and sometimes zero..... We usually eat at } \\
\text { home." }\end{array}$ \\
\hline
\end{tabular}




\begin{tabular}{|l|l|}
\hline \multicolumn{2}{|c|}{ (Table 4 Continued) } \\
\hline Qualitative Theme & Evidence \\
\hline "It got us [family] thinking... the one with the \\
grocery shopping where you go to the store and \\
you look at labels and you look at like the things \\
that you would buy and like look at the label and be \\
like wow, I can't believe I eat this." \\
"As a family we have like a chart that we write \\
down like our meals for the week." \\
When asked if the parents learned anything from \\
the Family Fun Packs: \\
"How to make cornbread."
\end{tabular}

\section{Mixed Methods Results}

After the quantitative and qualitative data were analyzed independently, the results were merged together. Three of the five qualitative themes aligned with quantitative data collected from the baseline and follow-up surveys. Table 5 provides a side-by-side comparison of the emerged themes and survey results. 


\begin{tabular}{|c|c|c|c|}
\hline \multicolumn{4}{|c|}{$\begin{array}{l}\text { Table } 5 \\
\text { Side-by-side comparison of qualitative themes and quantitative results with } \\
\text { mixed methods interpretation and implications }\end{array}$} \\
\hline Theme & $\begin{array}{l}\text { Qualitative } \\
\text { Findings }\end{array}$ & $\begin{array}{l}\text { Quantitative } \\
\text { Findings }\end{array}$ & $\begin{array}{l}\text { Mixed Methods } \\
\text { Interpretation }\end{array}$ \\
\hline $\begin{array}{l}\text { KidQuest } \\
\text { is Fun }\end{array}$ & $\begin{array}{l}\text { "Fun" was } \\
\text { identified } \\
\text { numerous times } \\
\text { relating to the } \\
\text { KidQuest } \\
\text { curriculum, } \\
\text { physical activities, } \\
\text { and the Family } \\
\text { Fun Packs. One } \\
\text { individual } \\
\text { indicated she } \\
\text { would join } \\
\text { KidQuest club } \\
\text { again if offered. }\end{array}$ & -........ & $\begin{array}{l}\text { KidQuest was "fun", } \\
\text { specifically the } \\
\text { curriculum, the } \\
\text { modified physical } \\
\text { activities, and the } \\
\text { Family Fun Packs. }\end{array}$ \\
\hline $\begin{array}{c}\text { Knowledge } \\
\text { Gained }\end{array}$ & $\begin{array}{l}\text { Participants } \\
\text { recalled many } \\
\text { lessons and } \\
\text { activities taught in } \\
\text { KidQuest. Also, } \\
\text { participants } \\
\text { identified the } \\
\text { following: } \\
\text { - healthy cooking } \\
\text { methods } \\
\text { - general tips for } \\
\text { identifying } \\
\text { healthy foods } \\
\text { - recommended } \\
\text { servings of milk } \\
\text { per day } \\
\text { - whether a } \\
\text { product is whole } \\
\text { grain or not } \\
\text { - high sugar } \\
\text { content in } \\
\text { sugar-sweetened } \\
\text { beverages }\end{array}$ & $\begin{array}{l}\text { The percent of } \\
\text { participants who } \\
\text { correctly answered } \\
\text { the question } \\
\text { regarding the } \\
\text { combined number } \\
\text { of fruits and } \\
\text { vegetables to } \\
\text { consume each day } \\
\text { increased from } 0 \% \\
\text { at baseline to } 40 \% \\
\text { at follow-up. } \\
\text { Participants } \\
\text { reported the } \\
\text { following: } \\
\text { - a slight increase } \\
\text { in the } \\
\text { consumption of } \\
\text { fruits, } \\
\text { vegetables, and } \\
\text { whole grains. }\end{array}$ & $\begin{array}{l}\text { Participants gained } \\
\text { knowledge on the } \\
\text { recommended } \\
\text { number of combined } \\
\text { servings of fruits and } \\
\text { vegetables and } \\
\text { increased their } \\
\text { consumption of } \\
\text { fruits and } \\
\text { vegetables. } \\
\text { Participants gained } \\
\text { knowledge on how } \\
\text { to identify whole } \\
\text { grain products and } \\
\text { increased their daily } \\
\text { consumption of } \\
\text { whole grains. }\end{array}$ \\
\hline
\end{tabular}




\begin{tabular}{|c|c|c|c|}
\hline \multicolumn{4}{|c|}{ (Table 5 Continued) } \\
\hline Theme & $\begin{array}{l}\text { Qualitative } \\
\text { Findings }\end{array}$ & $\begin{array}{l}\text { Quantitative } \\
\text { Findings }\end{array}$ & $\begin{array}{l}\text { Mixed Methods } \\
\text { Interpretation }\end{array}$ \\
\hline $\begin{array}{c}\text { Physical } \\
\text { Activity } \\
\text { Time }\end{array}$ & $\begin{array}{l}\text { Participants } \\
\text { reported that, } \\
\text { "Physical activity } \\
\text { time was fun" on } \\
\text { many occasions. }\end{array}$ & $\begin{array}{l}\text { Participants } \\
\text { reported nearly no } \\
\text { change in the } \\
\text { frequency of } \\
\text { physical activity } \\
\text { with adult members } \\
\text { of the household. }\end{array}$ & $\begin{array}{l}\text { Physical activity } \\
\text { time was the most } \\
\text { desired component } \\
\text { of KidQuest; } \\
\text { however, it did not } \\
\text { change the amount } \\
\text { of physical activity } \\
\text { completed at home } \\
\text { with adult household } \\
\text { members. }\end{array}$ \\
\hline $\begin{array}{l}\text { Behavior } \\
\text { Change }\end{array}$ & $\begin{array}{l}\text { The following } \\
\text { behavior changes } \\
\text { were noted: } \\
\text { - increased milk } \\
\text { consumption } \\
\text { - increased family } \\
\text { meal planning } \\
\text { - increased } \\
\text { parental } \\
\text { knowledge on } \\
\text { how to make a } \\
\text { healthy recipe }\end{array}$ & $\begin{array}{l}\text { Participants } \\
\text { reported an increase } \\
\text { in the use of a } \\
\text { nutrition food label } \\
\text { from } 37.5 \% \text { at } \\
\text { baseline to } 50 \% \text { at } \\
\text { follow-up. } \\
\text { Participants } \\
\text { reported a decrease } \\
\text { in the frequency of } \\
\text { helping plan or } \\
\text { cook meals for } \\
\text { themselves or their } \\
\text { family from. }\end{array}$ & $\begin{array}{l}\text { While one } \\
\text { participant reported } \\
\text { that she is now } \\
\text { helping her family } \\
\text { plan meals, the } \\
\text { quantitative data } \\
\text { indicated that } \\
\text { participants } \\
\text { decreased the } \\
\text { frequency of helping } \\
\text { plan and cook family } \\
\text { meals. }\end{array}$ \\
\hline $\begin{array}{c}\text { Recomme- } \\
\text { ndations } \\
\text { for Future } \\
\text { KidQuest } \\
\text { Programs }\end{array}$ & $\begin{array}{l}\text { The following } \\
\text { recommendations } \\
\text { were made by } \\
\text { participants: } \\
\text { - more physical } \\
\text { activity time } \\
\text { - more activities } \\
\text { in the nutrition } \\
\text { lessons and } \\
\text { Family Fun } \\
\text { Packs }\end{array}$ & --- & $\begin{array}{l}\text { Participants } \\
\text { recommended more } \\
\text { time for physical } \\
\text { activity as well as } \\
\text { more activities for } \\
\text { the nutrition lessons } \\
\text { and Family Fun } \\
\text { Packs. }\end{array}$ \\
\hline
\end{tabular}




\section{CHAPTER V}

\section{DISCUSSION \& CONCLUSION}

Researchers suggest that afterschool hours can make a lasting impact on the early adolescence population (Afterschool Alliance, 2009). The purpose of this pilot study was to evaluate the effectiveness of using a nutrition and physical activity intervention developed for the traditional school day in an afterschool setting. The researchers hypothesized that following the KidQuest intervention, participants would use nutrition related knowledge and skills learned to improve self-efficacy and change behavior. While the sample size was not large enough to statistically analyze the results, three of the five qualitative themes aligned with the quantitative findings.

Participants reported three behavior changes as a result of KidQuest. Two of the changes included family engagement which researchers identify as an important element to reducing obesity (Golan \& Crow, 2004; Gilman, et al., 2000). According to Gilman and colleagues (2000), families that eat together are more likely to eat a healthier, balanced meal. One participant noted that after learning about the benefits of dairy, she increased her milk consumption from one or two cups to four cups per day. The same participant also reported that the Family Fun Packs helped her family plan meals together. In addition, she stated that her family looks at labels to make healthier food choices.

The third behavior change noted involved parental involvement. One participant reported that his parents learned how to make corn bread. This suggests that the families looked through the Family Fun Packs and demonstrated initiative by preparing the recipes provided. 
In addition to the behavior changes, participants provided valuable recommendations for future implementation of KidQuest intervention. While participants repeatedly identified KidQuest as "fun", the emphasis was on the physical activity time, not the nutrition lessons. When asked what could be done differently, the majority of participants stated more time for physical activity and more activities in the nutrition lessons and Family Fun Packs. These recommendations may be related to the methods used to deliver the nutrition lessons. While KidQuest was developed with hands-on activities, it was designed for the traditional school day. KidQuest may need additional activities or a different method of nutrition lesson delivery when implemented in the afterschool setting.

Two of the five qualitative themes were not measured in the quantitative findings, reinforcing the need to include the qualitative evaluation component. As a result, future researchers who implement KidQuest should consider adding closed-ended survey questions that measure: (1) How fun KidQuest is and (2) Participant recommendations for future KidQuest implementation.

While the quantitative results of the study pose limited findings, the result of this pilot study identified potential barriers to conducting research in the afterschool setting and recommendations for future implementation of KidQuest in Nebraska.

\section{Program Delivery}

KidQuest curriculum was designed to be implemented within a six month time period; however, this pilot study implemented the intervention within six weeks based on the demands of the afterschool programs. The afterschool programs that participated in the study rotate their clubs every school quarter or six to eight weeks, respectively. The 
program team considered implementing the intervention over two quarters; but there was a concern that participants would sign up for a program other than KidQuest for the second quarter.

\section{Participant Compliance and Data Collection}

Researchers recommend interventions provide a minimum of six lessons to promote behavior change (Conway, Kennel, \& Zubieta). In this pilot study, very few participants attended KidQuest consistently throughout the intervention due to irregular attendance in the afterschool setting. The afterschool programs that participated in the study also allow adolescents to "club hop" which gives adolescents the ability to switch afterschool clubs as they desire. While this promotes a healthy decision making environment, it poses a barrier for individuals conducting research on a specific program.

Attendance during data collection days was unpredictable, even when the afterschool program director strongly encouraged participants to attend. Some participants joined after the baseline data collection was conducted. In these cases, participants received valuable nutrition education; however, the baseline survey data were not collected. Other researchers have identified inconsistent participation rates as a barrier to conducting research in the afterschool setting (Little et al., 2008). Future researchers who implement KidQuest should explore the use of a modified baseline survey for participants who join after the baseline data collection.

Another barrier identified in this study was obtaining signed parental informed consent. Participants had to be reminded to bring or send in the signed consent. Some participants wanted to participate in the focus group session; however, their parents were 
not willing to sign the parental informed consent. This may be explained by a lack of parental understanding and hesitation involved with data collection.

Considerations for Focus Groups with Middle School Adolescents

Social desirability is defined as the tendency for an individual to answer a question based on the perception of what is acceptable by their peers (Spector, 2004). One way to address social desirability when using focus groups is to consider the participants who are grouped together. Krueger and Casey (2009, p.155-160) recommend to avoid grouping close friends together and to be aware of age-related behaviors, especially when working with middle school adolescents. When males and females are grouped together, Krueger and Casey describe the situation as "chaotic".

One of the focus groups conducted in this study grouped friends and genders together. As a result, the participants spent a large portion of the session laughing which limited the quality of data that was collected. Separating the genders would have resulted in one male interview and not in a focus group. If the sample size would have been larger, a greater possibility to split male and female participants would occur.

In another focus group session, one of the participants provided erroneous and irrelevant answers including, "you shouldn't really have like a lot of vitamins cause it could like make you get like cold sores in your mouth and stuff and sometimes it really hard to get them to go away," and "don't drink curdled milk." After the focus group session, the instructor of the KidQuest curriculum confirmed that the erroneous and irrelevant content was not taught in the lessons. When conducting focus groups, it is important to consider the developmental age of the participants and recognize methods to acquire quality data. 


\section{Participant Recommendations for Future KidQuest Implementation}

Lastly, participants provided valuable recommendations for future implementation of KidQuest in the afterschool setting. KidQuest was purposefully designed with hands on activities to promote participant engagement. As suggested by the participants of this pilot study, more activities should be included in KidQuest when implemented in the afterschool setting.

\section{Conclusion}

Overall, the adolescents who participated in the intervention were exposed to nutrition education and a healthy environment where physical activity was considered "fun". While the results of this study were not conclusive, participants reported three behavior changes and provided recommendations for future implementation of KidQuest.

The evaluation of this pilot study helped identify necessary considerations in implementing KidQuest in afterschool programs in Lincoln, Nebraska. Four important considerations when adapting a nutrition and physical intervention designed for the traditional school day for an afterschool setting includes: (1) Participant compliance, (2) Methods of engaging adolescents to promote behavior change, (3) Evaluation methods to ensure outcomes are being measured, and (4) Flexibility of data collection with consideration of modified surveys for participants who join after baseline data collection.

As a result of this study, the program team has decided to alter future programming by continuing the structured physical activity time in the afterschool program while re-directing the nutrition intervention towards the traditional school day. To provide a nutrition education component in the afterschool setting, future researchers should consider incorporating nutrition into the food preparation component. 


\section{Limitations}

This study has limitations that should be taken into consideration. While this study utilized convenient sampling, the sample size was smaller than desired which eliminated the use of process evaluation and the use of statistics to analyze the quantitative findings. A larger sample would have allowed more statistical analysis. Another limitation was the survey modification during the intervention to ensure the outcomes of the grant were being measured. Due to the nature of this study, the results may not be representative to all adolescents who participate in afterschool programs.

\section{Implications for Future Research}

Because of the potential for afterschool programs to reach the early adolescent population, additional research is needed to identify effective strategies for implementing traditional school nutrition interventions in the afterschool setting. Questions that remain unanswered as a result of this study include: What is the efficacy of using a survey for participants who join after baseline data collection? What are other avenues to reach adolescents consistently in the afterschool hours? Would KidQuest be more effective if afterschool staff delivered the intervention? Would it be more effective if peers taught their peers? If so, what would be the steps required to train afterschool staff or peer education? 


\section{References}

Afterschool Alliance. (2007). Afterschool programs: Making a difference in America's communities by improving academic achievement, seeping kids safe and helping working families. Retrieved from http://www.afterschoolalliance.org/documents/outcomes_0208.pdf

Afterschool Alliance. (2007). ABC...123: Starting your afterschool program. Retrieved from http://www.afterschoolalliance.org/Utah4HAfterschoolGuide.pdf

Afterschool Alliance. (2009). America after 3 PM: The most in-depth study of how America's children spend their afternoons. Retrieved from http://www.afterschoolalliance.org/documents/AA3PM_National_2009.pdf

American Dietetic Association. (2006). Position of the American Dietetic Association: Individual-, family-, school-, and community-based interventions for pediatric overweight. Journal of the American Dietetic Association, 106(6), 925-45. doi: 10.1016/j.jada.2006.03.001

American Dietetic Association. (2010). Position of the American Dietetic Association. School Nutrition Association, and Society for Nutrition Education: Comprehensive school nutrition services. Journal of the American Dietetic Association, 110, 1738-1749. doi: 10.1016/j.jada.2010.08.035

American Youth Policy Forum. (2006). Helping youth succeed through out-of-school time programs. Retrieved from http://www.aypf.org/resources/helpingyouthsucceed/?documenttype=18\&search= advanced

Anderson, E. S., Winett, R. A., \& Wojcik, J. R. (2007). Self-regulation, self-efficacy, outcome expectations, and social support: Social cognitive theory and nutrition behavior. Annals of Behavioral Medicine, 34(3), 304-12. doi: 10.1007/BF02874555

Bayne-Smith, M., Fardy, P. S., Azzollini, A., Magel, J., Schmitz, K. H., \& Agin, D. (2004). Improvements in heart health behaviors and reduction in coronary artery disease risk factors in urban teenaged girls through a school-based intervention: The PATH program. American Journal of Public Health, 94(9), 1538-43.

Centers for Disease Control and Prevention. (1996, July). Nutrition education in public elementary and secondary schools. National Center for Education Statistics. Retrieved from http://nces.ed.gov/pubs/96852.pdf 
Centers for Disease Control and Prevention. (2003, August 22). Physical activity levels among children aged 9-13 years: United States, 2002. Retrieved from http://www.cdc.gov/mmwr/preview/mmwrhtml/mm5233a1.htm

Centers for Disease Control and Prevention. (2011). Behavior Risk Factor Surveillance Survey: Prevalence and trends data for overweight and obesity. Retrieved from http://apps.nccd.cdc.gov/BRFSS/list.asp?cat=OB\&yr=2011\&qkey=8261\&state= Alls

Centers for Disease Control and Prevention. (2011). Youth Risk Behavior Surveillance Survey: Adolescent and school health. Retrieved from http://www.cdc.gov/healthyyouth/yrbs/factsheets/index.htm\#compare

Centers for Disease Control and Prevention. (2011). The obesity epidemic and United States students. Retrieved from http://www.cdc.gov/healthyyouth/yrbs/pdf/us_obesity_combo.pdf

Centers for Disease Control and Prevention. (2013). Childhood obesity facts. Retrieved from http://www.cdc.gov/healthyyouth/obesity/facts.htm

Cheng, G., Buyken, A. E., Shi, L., Karaolis-Danckert, N., Kroke, A., Wudy, S. A., Degen, G. H., \& Rember, T. (2012). Beyond overweight: Nutrition as an important lifestyle factor influencing timing of puberty. Nutrition Reviews, 70(3), 133-152. doi:10.1111/j.1753-4887.2011.00461.x

Contento, I. R. (2011). Nutrition education: Linking research, theory, and practice $\left(2^{\text {nd }}\right.$ ed.). Sudburry, MA: Jones and Bartlett Publishing.

Conway, C., Kennel, J., \& Zubieta, A. C. Assessing optimal nutrition education dosage and long-term behavior change retention in SNAP-Ed participants. Received from http://www.nifa.usda.gov/nea/food/fsne/pdfs/ohio_improv_SnapEd_ACZ_Fin.pdf

Creswell, J. W. (2009). Research design: Qualitative, quantitative, and mixed methods approaches. Thousand Oaks, CA: SAGE Publications.

Creswell, J. W., \& Plano Clark, V. L. (2007). Designing and conducting mixed methods research. Thousand Oaks, CA: SAGE Publications.

Cross, A. B., Gottfredson, D. C., Wilson, D. M., Rorie, M., \& Connell, N. (2009).The impact of after-school programs on the routine activities of middle-school students: Results from a randomized, controlled trial. Criminology \& Public Policy, 8(2) 391-412. doi: 10.1111/j.1745-9133.2009.00555.x 
Datar, A., \& Sturm, R. (2004). Physical education in elementary school and body mass index: evidence from the early childhood longitudinal study. American Journal of Public Health, 94(9), 1501-6. doi: 10.2105/AJPH.2007.117176

DeBar, L. L., Stevens, V. J., Perrin, N., Wu, P., Pearson, J., Yarborough, B. J., Dickerson, M. S., \& Lynch, F. (2012). A primary care-based, multicomponent lifestyle intervention for overweight adolescent females. Pediatrics, 129(3), 611620. doi: 10.1542/peds.2011-0863

Della Torre S. B., Akré, C., \& Suris, J. C. (2010). Obesity prevention opinions of school stakeholders: A qualitative study. Journal of School Health, 80(5), 233-9. doi: 10.1111/j.1746-1561.2010.00495.x

Dennehy, J., Gannett, E., \& Robbins, R. (2006). Setting the stage for a youth development associate credential: A national review of professional credentials for the out-of-school time workforce. Received from http://www.nextgencoalition.org/docs/youth-dev-setting-NIOST.pdf

Durlak, J. A., Weissberg, R. P., \& Pachan, M. (2010). A meta-analysis of after-school programs that seek to promote personal and social skills in children and adolescents. American Journal of Community Psychology, 45(3-4), 294-309. doi: 10.1007/s10464-010-9300-6

Elkins, W. L., Cohen, D. A., Koralewicz, L. M., \& Taylor, S. N. (2004). After school activities, overweight, and obesity among inner city youth. Journal of Adolescence, 27(2), 181-9. doi:10.1016/j.adolescence.2003.10.010

Erikson, J. (2006). Brain food: The real dish on nutrition and brain function. WisKids Journal, November/December. Retrieved from http://www.wccf.org/wkj/1106/story7.htm

Gannett, E. S., Mello, S., \& Starr, E. (2009). Credentialing for 21st CCLC staff: An overview of the benefits and impacts. Retrieved from http://www.wcwonline.org/component/option,com_virtuemart/category_id,340/fl ypage,flypage-niost.tpl/page,shop.product_details/product_id,1641/

Gillman, M. W., Rifas-Shiman, S. L., Frazier, A. L., Rockett, H. R., Camargo, C. A. Jr, Field, A. E., Berkey, C. S., \& Colditz, G. A. (2000). Family dinner and diet quality among older children and adolescents. Archive of Family Medicine, 9(3), 235-40.

Glanz, K., Rimer, B. K., \& Viswanath, K. (2008). Health behavior and health education: Theory, research, and practice ( $4^{\text {th }}$ ed.). San Francisco, CA: Jossey-Bass. 
Golan, M., \& Crow, S. (2004). Targeting parents exclusively in the treatment of childhood obesity: Long term results. Obesity Research, 12(2), 357-361.

Gonzalez-Suarez, C., Worley, A., Grimmer-Somers, K., \& Dones, V. (2009). Schoolbased interventions on childhood obesity: A meta-analysis. American Journal of Preventative Medicine, 37(5), 418-27. doi: 10.1016/j.amepre.2009.07.012

Hoelscher, D. M., Evans, A., Parcel, G. S., \& Kelder, S. H. (2002). Designing effective nutrition interventions for adolescents. Journal of the American Dietetic Association, 102(3), S52-63. doi:10.1016/S0002-8223(02)90422-0

Institute of Medicine (2012). Accelerating progress in obesity prevention. Washington, DC: The National Academies Press.

Jensen, B., Kattelmann, K., Ren, C., \& Wey, H. (2009). The efficacy of KidQuest: A nutrition and physical activity curriculum for 5th and 6th grade youth. Journal of Extension, 47(3). Retrieved from http://www.joe.org/joe/2009june/a4.php

Kahne, J., Nagaoka, J., Brown, A., O'Brien, J., Quinn, T., \& Thiede, K. (2001). Assessing after-school programs as contexts for youth development. Youth Society, 32(4), 421-46. doi: 10.1177/0044118X01032004002

Kann, L., Brener, N. D., \& Wechsler, H. (2007). Overview and summary: School Health Policies and Programs Study 2006. Journal of School Health, 77(8), 385-397.

Kropski, J. A., Keckley, P. H., \& Jensen, G. L. (2008). School-based obesity prevention programs: An evidence-based review. Obesity (Silver Spring), 16(5), 1009-18. doi: 10.1038/oby.2008.29

Krueger, R. A., \& Casey, M. A (2009). Focus groups: A practical guide for applied research $\left(4^{\text {th }} e d.\right)$. Thousand Oaks, CA: Sage Publications.

Lee, S. M., Burgeson, C. R., Fulton, J. E., \& Spain, C. G. (2006). Physical education and physical activity: results from the School Health Policies and Programs Study 2006. Journal of School Health, 77(8), 435-63.

Little, P., Wimer, C., \& Weiss, H. B. (2008). After school programs in the 21st century: Their potential and what it takes to achieve it. Harvard Family Research Project. Retrieved from http://www.hfrp.org/publications-resources/browse-ourpublications/after-school-programs-in-the-21st-century-their-potential-and-whatit-takes-to-achieve-it

Mahoney, J. L. , Lord, H., \& Carryl, E. (2005). Afterschool program participation and the development of child obesity and peer acceptance. Applied Developmental Science, 9(4), 202-215. doi:10.1207/s1532480xads0904_3 
National Association of State Boards of Education. (2012). State School Healthy Policy Database. Retrieved from http://www.nasbe.org/healthy_schools/hs/bytopics.php?catExpand=acdnbtm_catC

National Center for Health Statistics. (2012). Health, United States, 2011: With special features on socioeconomic status and health. Retrieved from http://www.cdc.gov/nchs/data/hus/hus11.pdf

Plano Clark, V. L., \& Creswell, J. W. (2010). Understanding research: A consumer's guide. Upper Saddle River, New Jersey: Pearson Education.

Reedy, J., \& Krebs-Smith, S. M. (2010). Dietary sources of energy, solid fats, and added sugars among children and adolescents in the United States. Journal of the American Dietetic Association, 110(10), 1477-84. doi: 10.1016/j.jada.2010.07.010

Russell, S., \& Bakken, R. J. (2002). Development of autonomy in adolescence. Retrieved from http://www.ianrpubs.unl.edu/epublic/archive/g1449/build/g1449.pdf

Shaya, F. T., Flores, D., Gbarayor, C. M., \& Wang, J. (2008). School-based obesity interventions: A literature review. Journal of School Health, 78(4), 189-96. doi: 10.1111/j.1746-1561.2008.00285.x

Spector, P. E. (2004). Social desirability bias. SAGE Encyclopedia of Social Science Research Methods. doi: 10.4135/9781412950589. Received from http://srmo.sagepub.com/view/the-sage-encyclopedia-of-social-science-researchmethods/n932.xml

Story, M., Neumark-Sztainer, D., \& French, S. (2002). Individual and environmental influences on adolescent eating behaviors. Journal of American Dietetic Association, 102(3), S40-S51. doi:10.1016/S0002-8223(02)90421-9

US Department of Agriculture. Child and Adult Care Food Program: Afterschool care snacks cycle menus. Retrieved from http://www.fns.usda.gov/cnd/care/RegsPolicy/Snacks/Cycle_Menu.htm

US Department of Agriculture \& US Department of Health and Human Services. 2010 Dietary Guidelines for Americans ( $7^{\text {th }}$ ed.). New York, NY: Russell Sage Foundation.

US Department of Education. (2009, August 13). No Child Left Behind: A toolkit for teachers. Received from http://www2.ed.gov/teachers/nclbguide/toolkit_pg10.html 
US Department of Health and Human Services. (2006). Overview: School health policies and programs. Retrieved from http://www.cdc.gov/healthyyouth/shpps/2006/factsheets/pdf/FS_Overview_SHPP S2006.pdf

US Department of Health and Human Services. (2006). Promoting physical activity and healthy nutrition in afterschool settings: Strategies for program leaders and policy makers. Received from http://www.researchconnections.org/childcare/resources/13558/pdf

US Department of Health and Human Services. (2008). 2008 Physical Activity Guidelines for Americans. Received from http://www.health.gov/paguidelines/guidelines/default.aspx

US Department of Health and Human Services \& Centers for Disease Control and Prevention. (2010, June 8). Morbidity and mortality weekly report. Surveillance Summaries, 61(4). Retrieved from http://www.cdc.gov/healthyyouth/yrbs/overall.htm

US Department of Justice. (2001). The YMCA's teen action agenda: Office of Justice Program fact sheet. Retrieved from https://www.ncjrs.gov/pdffiles1/ojjdp/fs200114.pdf

Wiecha, J. L., Hall, G., Gannett, E., \& Roth, B. (2012). Healthy eating in out-of-school time: The promise and the challenge. Afterschool Matters, 15. Retrieved from http://www.niost.org/pdf/afterschoolmatters/asm_2012_15_spring/asm_2012_15_ spring.pdf

Wiecha, J. L., Gannett, E., Hall, G., \& Roth, B. (2011). Healthy eating and physical activity in out-of-school time. Retrieved from http://www.naaweb.org/default.asp?contentID=672

Zapata, L. B., Bryant, C. A., McDermott, R. J., \& Hefelfinger, J. A. (2008). Dietary and physical activity behaviors of middle school youth: The youth physical activity and nutrition survey. Journal of School Health, 78(1), 9-18. doi: 10.1111/j.17461561.2007.00260.x 
Appendices 
Appendix A

University of Nebraska-Lincoln

Institutional Review Board Letter of Approval - KidQuest Program Delivery 
Sent By: IRB NUgrant System

Sent On: 04/05/2012 05:57 pm

Reference: Workflow - 75171

Subject: Official Approval Letter for IRB project \#12329

Message: April 5, 2012

Wanda Koszewski

Department of Nutrition and Health Sciences

119A LEV, UNL, 68583-0806

Jean Fischer

Department of Nutrition and Health Sciences

119B LEV, UNL, 68583-0806

IRB Number: 20120412329EP

Project ID: 12329

Project Title: Transdisciplinary Childhood Obesity Prevention Project

Dear Wanda:

This letter is to officially notify you of the approval of your project by the Institutional Review Board (IRB) for the Protection of Human Subjects. It is the Board's opinion that you have provided adequate safeguards for the rights and welfare of the participants in this study based on the information provided. Your proposal is in compliance with this institution's Federal Wide Assurance 00002258 and the DHHS Regulations for the Protection of Human Subjects (45 CFR 46). Your project was approved as an Expedited protocol, category 7.

Date of EP Review: 04/02/2012

You are authorized to implement this study as of the Date of Final Approval: 04/05/2012. This approval is Valid Until: 04/04/2013.

We wish to remind you that the principal investigator is responsible for reporting to this Board any of the following events within 48 hours of the event:

* Any serious event (including on-site and off-site adverse events, injuries, side effects, deaths, or other problems) which in the opinion of the local investigator was unanticipated, involved risk to subjects or others, and was possibly related to the research procedures;

* Any serious accidental or unintentional change to the IRB-approved protocol that involves risk or has the potential to recur;

* Any publication in the literature, safety monitoring report, interim result or other finding that indicates an unexpected change to the risk/benefit ratio of the research; * Any breach in confidentiality or compromise in data privacy related to the subject or others; or

* Any complaint of a subject that indicates an unanticipated risk or that cannot be resolved by the research staff.

For projects which continue beyond one year from the starting date, the IRB will request continuing review and update of the research project. Your study will be due for continuing review as indicated above. The investigator must also advise the Board when this study is finished or discontinued by completing the enclosed Protocol Final Report form and returning it to the Institutional Review Board.

If you have any questions, please contact the IRB office at 472-6965.

Sincerely, 


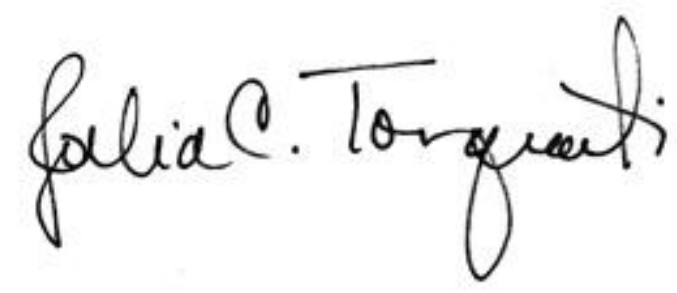

Julia Torquati, Ph.D.

Chair for the IRB

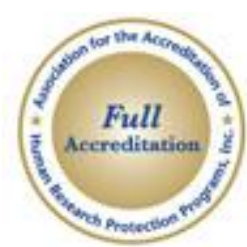




\section{Appendix B}

University of Nebraska-Lincoln, Institutional Review Board Letter of Approval Protocol Change (Focus Group)

Request for Change, June 28, 2012 
Sent By: IRB NUgrant System

Sent On: 06/28/2012 07:03 am

Reference: Workflow - 79709

Subject: Official Approval Letter for IRB project \#12329

Message: June 27, 2012

\author{
Wanda Koszewski \\ Department of Nutrition and Health Sciences \\ 119A LEV, UNL, 68583-0806 \\ Jean Fischer \\ Department of Nutrition and Health Sciences \\ 119B LEV, UNL, 68583-0806
}

IRB Number: 20120412329EP

Project ID: 12329

Project Title: Transdisciplinary Childhood Obesity Prevention Project

\title{
Dear Wanda:
}

The Institutional Review Board for the Protection of Human Subjects has completed its review of the Request for Change in Protocol submitted to the IRB.

**It has been approved to conduct focus groups to evaluate the effectiveness of the KidQuest program. **

We wish to remind you that the principal investigator is responsible for reporting to this Board any of the following events within 48 hours of the event:

* Any serious event (including on-site and off-site adverse events, injuries, side effects, deaths, or other problems) which in the opinion of the local investigator was unanticipated, involved risk to subjects or others, and was possibly related to the research procedures;

* Any serious accidental or unintentional change to the IRB-approved protocol that involves risk or has the potential to recur;

* Any publication in the literature, safety monitoring report, interim result or other finding that indicates an unexpected change to the risk/benefit ratio of the research;

* Any breach in confidentiality or compromise in data privacy related to the subject or others; or

* Any complaint of a subject that indicates an unanticipated risk or that cannot be resolved by the research staff.

This letter constitutes official notification of the approval of the protocol change. You are therefore authorized to implement this change accordingly.

If you have any questions, please contact the IRB office at 472-6965.

Sincerely,

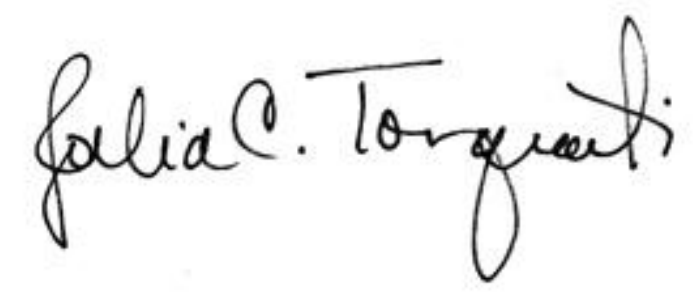

Julia Torquati, Ph.D.

Chair for the IRB 


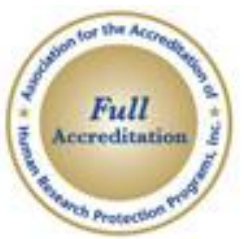




\section{Appendix C}

University of Nebraska-Lincoln, Institutional Review Board Letter of Approval -

Protocol Change (modified baseline survey and use of the revised assent form to state corrected time requirements)

Request for Change, September 18, 2012 
Sent By: $\quad$ IRB NUgrant System

Sent On: 09/18/2012 06:26 am

Reference: Workflow - 83626

Subject: Official Approval Letter for IRB project \#12329

Message: September 17, 2012

\author{
Wanda Koszewski \\ Department of Nutrition and Health Sciences \\ 119A LEV, UNL, 68583-0806 \\ Jean Fischer \\ Department of Nutrition and Health Sciences \\ 119B LEV, UNL, 68583-0806
}

IRB Number: 20120412329EP

Project ID: 12329

Project Title: Transdisciplinary Childhood Obesity Prevention Project

Dear Wanda:

The Institutional Review Board for the Protection of Human Subjects has completed its review of the Request for Change in Protocol submitted to the IRB.

${ }^{* *}$ It has been approved for use of the revised survey, implementation of a pre/post survey and observation tool, removal of physical measurements from the parental procedures, implementation of payment by check, and use of the revised assent form to state corrected time requirements. ${ }^{* *}$

We wish to remind you that the principal investigator is responsible for reporting to this Board any of the following events within 48 hours of the event:

* Any serious event (including on-site and off-site adverse events, injuries, side effects, deaths, or other problems) which in the opinion of the local investigator was unanticipated, involved risk to subjects or others, and was possibly related to the research procedures;

* Any serious accidental or unintentional change to the IRB-approved protocol that involves risk or has the potential to recur;

* Any publication in the literature, safety monitoring report, interim result or other finding that indicates an unexpected change to the risk/benefit ratio of the research;

${ }^{*}$ Any breach in confidentiality or compromise in data privacy related to the subject or others; or

* Any complaint of a subject that indicates an unanticipated risk or that cannot be resolved by the research staff.

This letter constitutes official notification of the approval of the protocol change. You are therefore authorized to implement this change accordingly.

If you have any questions, please contact the IRB office at 472-6965.

Sincerely, 
56

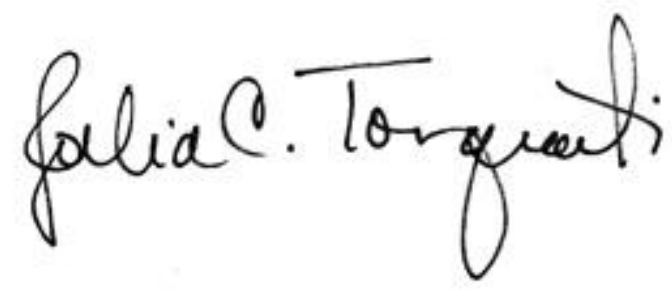

Julia Torquati, Ph.D.

Chair for the IRB

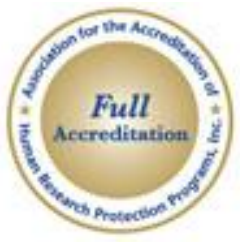




\section{Appendix D}

Lincoln Public Schools, Letter of Approval 


\section{Lincoln Public Schools 949 West Bond $•$ Box 82889 $\begin{aligned} & \bullet \text { Lincoln, NE } 68501 \\ & 1790\end{aligned}$}

RR 12-47

February 6, 2012

Wanda Koszewski, Ph.D.

wkoszewski1@unl.edu

Jean Fischer, Ph.D.

jifischer6@unl.edu

Department of Nutrition and Health Sciences

RE: Request to Conduct Research

Dear Dr. Koszewski and Dr. Fischer,

Your request to conduct a study entitled "Transdisciplinary Childhood Obesity Prevention Project" with students enrolled in an afterschool program at a Lincoln Public Schools Community Learning Center is approved. Please contact Josh Cramer, Federal Programs Supervisor, to secure his permission to proceed with the implementation of this study. Parent/guardian consent and student assent are required for this study. Please use the forms and procedures submitted with your request.

Sincerely,

Leslu E. Oukin

Leslie E. Lukin, Ph.D.

Director of Assessment and Evaluation Services

cc: Josh Cramer, Federal Programs Supervisor

Deila Steiner, Director of Federal Programs

Title of Research: Transdisciplinary Childhood Obesity Prevention Project 
Appendix E

Parental Informed Consent, KidQuest Curriculum and Surveys 


\section{Nebraska Lincoln \\ Effectiveness of an Afterschool Nutrition and Physical Activity Club: KidQuest Club}

Dear Parent/Guardian:

We are excited to announce that your child has the opportunity to participate in an educational program called The KidQuest Club (Fitness, Food, and Fun). The goals of the program are to increase physical activity patterns and improve overall eating behaviors. The program will be provided during eight sessions during the Dawes Middle School Afterschool Program. It will be located at their assignment classrooms for the afterschool program at Dawes Middle School. Participation in KidQuest over the quarter will allow your child to learn more about nutrition and healthy food choices and ways to increase overall physical activity while having fun at the same time. Some of the nutrition topics will include the benefits of breakfast, smart snack and vending machine choices, and calcium intake. The physical activity sessions provided will introduce your child to fun ways that they can move every day in a short amount of time which still counts towards promoting overall health. Each session will last one hour including the first and last session in which the data will be collected. Your participation will be required during the first and last session which parent data will be collected. Each data collection session will be one hour in length.

This letter is a consent request for your child to participate in the KidQuest research project developed by the University of Nebraska-Lincoln (UNL) Nutrition Education Program. Our research project is designed to test the efficacy of the KidQuest Club in the afterschool setting.

We are requesting your permission to conduct the following evaluations pre, post, and 12 months following implementation of the program. Our research and evaluation methods have been approved by the University of Nebraska-Lincoln Human Subjects Research Review Board. Your child will be asked to do the following:

- Youth survey to assess eating and physical activity and other wellness related behaviors. A copy of this survey can be requested by contacting the project director listed on this consent form.

- Weight, height, waist circumference, body mass index, body fat and lean body mass percentage and blood pressure. Measurements will be done in a private setting with a lightweight shirt and shorts.

- Participants will also be asked to assess their perceived body image status using the Children's Body Image Scale (CBIS). The child points to the picture they feel best represents their body image status. A link to the CBIS pictures can be found at: http://adc.bmj.com/content/94/12/944.full.

Page 1 of 3 Initials 
Participation in this study is voluntary. You are free to decide not to enroll your child in this study. You can refuse to participate or withdraw your child at any time without harming their or your relationship with the researchers or the University Nebraska-Lincoln, (or other institutions or organizations), or in any other way receive penalty or loss of benefits to which you are otherwise entitled.

DOCUMENTATION OF INFORMED CONSENT

YOU ARE VOLUNTARILY MAKNG A DECISION WHETHER OR NOT TO ALLOW YOUR CHILD TO PARTICIPATE IN THE RESEARCH STUDY. YOUR SIGNITURE CERTIFIES THAT YOU HAVE DECIDED TO ALLOW YOUR CHILD TO PARTICIPATE HAVING READ AND UNDERSTOOD THE INFORMATION PRESENTED. YOU WILL BE GIVEN A COPY OF THIS CONSENT FORM TO KEEP.

Child's Name

Signature of Parent

Date 


\section{Appendix F}

Youth Informed Assent, KidQuest Curriculum and Surveys 


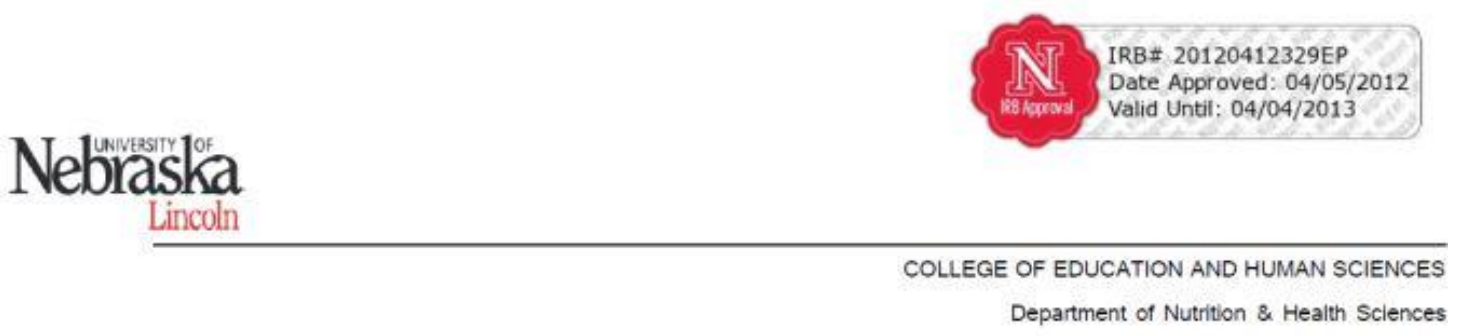

YOUTH ASSENT FORM

Effectiveness of the KidQuest Club in an AfterSchool Setting

This is an invitation for you to help in a study with the University of Nebraska-Lincoln. The project is called the KidQuest Club. We want to see if you will learn about healthy eating and exercise through the KidQuest program. If you agree to help, you will work with our team three times. Each time will about 30-45 minutes each. You will take a survey on eating and exercise. Your blood pressure will be taken and your height, weight and your waist/hip will be measured. We will be taking two skinfold measurements to determine your lean body mass and percent body fat. We will have you select from a list of pictures the one most closely resembling your body shape. You may also have the opportunity to wear an accelerometer to help us determine your physical activity level. Finally we will ask you to complete the President's Physical Fitness Challenge to determine your overall fitness level.

There is no risk associated with this study. The reason why we are doing this study is that it will us develop more affective afternoon nutrition and physical activity programs and clubs. Your responses will be strictly confidential. There will be no way for us to know which responses belong to you or someone else. We may publish a summary of everybody's responses or present such a summary at a scientific meeting, but your identity and your responses would be totally confidential.

Your parents will also be asked to give their permission for you to take part in this study. Please talk this over with your parents before you decide whether or not to participate. You do not have to be in this study if you do not want to. If you decide to participate in the study, you can stop at any time. If you choose to participate we will ask you to participate in the pre, post and 12 -month follow-up. You and your family will receive a $\$ 15.00$ gift card every time you participate in the research component of the KidQuest Club. However, you can still participate in the club without doing the research component.

If you have any questions at any time, please ask one of the researchers.

Signature of Subject Date

Signature of Investigator Date

INVESTIGATOR

Wanda M. Koszewski, PhD, RD, LMNT

Phone: $402-472-7966$ 
Appendix G

Recruitment Form, Focus Group 


\title{
Nebraska
}

Lincoln

COLLEGE OF EDUCATION AND HUMAN SCIENCES

Department of Nutrition \& Health Sciences

RECRUITMENT FORM

\section{Effectiveness of an Afterschool Nutrition and Physical Activity Club: KidQuest Club}

\author{
Dear Parent/Guardian:
}

We have come to the end of the educational program called KidQuest Club (Fitness, Food, and Fun). To evaluate the efficacy of this program, we will be conducting a focus group session. The focus group session will be one hour in length and will ask students what they thought of KidQuest and what they have learned. Attached is a consent form for your child to participate in the focus group session which includes information about the session.

If you have additional questions about the KidQuest program or the evaluation measures that will be used, please contact the project director listed below.

Wanda M. Koszewski, PhD, RD

Associate Extension Professor

119A Leverton Hall

Department of Nutrition and Health Sciences

University of Nebraska-Lincoln

Lincoln, NE 68583-0806

Telephone 402-472-7966 Fax 402-472-1587

Email: wkoszewski1@unl.edu 
Appendix H

Parental Informed Consent, Focus Group 


\section{Nebraska

PARENTAL INFORMED CONSENT FORM

Effectiveness of an Afterschool Nutrition and Physical Activity Club: KidQuest Club

Dear Parent/Guardian:

We have come to the end of the educational program called KidQuest Club (Fitness, Food, and Fun). To evaluate the efficacy of this program, we will be conducting a focus group session. The focus group session will be one hour in length and will ask students what they thought KidQuest and what they learned.

This letter is a consent request for your child to participate in the focus group session for KidQuest research project developed by the University of Nebraska-Lincoln (UNL) Nutrition Education Program. Our research and evaluation methods have been approved by the University of Nebraska-Lincoln Human Subjects Research Review Board. Your child will be asked to do the following:

- Answer questions regarding the efficacy of the program. A copy of these questions can be requested by contacting the project director listed on this consent form.

Participation in the focus group session is voluntary and you may withdraw your child at any time without penalty. Only youth in which received consent will be asked to participate in the evaluation.

The responses from the students will be recorded in writing and audio to recall accuracy of evaluation. Due to the nature of an open-discussion forum the investigators cannot guarantee participant confidentiality and that the youth participant should only discuss items that they feel comfortable discussing. Identities will not be recorded to protect the students. Result will aid in the evaluation of the program for future reference. The data (without any individual identifiers) may be submitted to professional journals and other publications and may be presented in a public setting.

If you have additional questions about the KidQuest program or the evaluation measures that will be used, please contact the project director listed below.

Wanda M. Koszewski, PhD, RD

Associate Extension Professor

119A Leverton Hall

Department of Nutrition and Health Sciences

University of Nebraska-Lincoln

Lincoln, NE 68583-0806

Telephone 402-472-7966 Fax 402-472-1587

Email: wkoszewski1@unl.edu 
Your child's rights as a research participant have been explained to you. You may ask questions concerning this research and have those questions answered before agreeing to participate in or during the study. Or you may call the investigator at any time at (402) 472-7966. Please contact the investigator:

- If you want to voice concerns or complaints about the research.

Please contact the University of Nebraska-Lincoln Institutional Review Board at (402) 472-6965 for the following reasons:

- You wish to talk to someone other than the research staff to obtain answers to questions about your rights as a research participant

- To voice concerns or complaints about the research

- To provide input concerning the research process

- In the event the study staff could not be reached.

Participation in this study is voluntary. You are free to decide not to allow your child to partake in evaluation of this program. You can refuse to participate or withdraw your child at any time without harming their or your relationship with the researchers or the University Nebraska-Lincoln, (or other institutions or organizations), or in any other way receive penalty or loss of benefits to which you are otherwise entitled.

We will contact you via email to confirm your assent and your parent's consent for participation in the focus group session. In the email we will also ask you to provide a day and time that would work best for your youth. We will conduct the session at Dawes Middle School, your home, or where ever is most convenient for your youth. You will not need to be present during the focus group session; however if you wish to be present you may.

If you have any questions at any time, please ask the researcher indicated above.

DOCUMENTATION OF INFORMED CONSENT

YOU ARE VOLUNTARILY MAKNG A DECISION WHETHER OR NOT TO ALLOW YOUR CHILD TO PARTICIPATE IN THE RESEARCH STUDY. YOUR SIGNITURE CERTIFIES THAT YOU HAVE DECIDED TO ALLOW YOUR CHILD TO PARTICIPATE HAVING READ AND UNDERSTOOD THE INFORMATION PRESENTED. YOU WILL BE GIVEN A COPY OF THIS CONSENT FORM TO KEEP.

Child's Name 


\section{Appendix I}

Youth Informed Assent, Focus Group 


\section{Nebraska Lincoln}

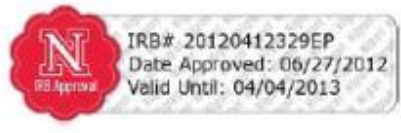

\section{YOUTH ASSENT FORM}

\section{Effectiveness of the KidQuest Club in an After School Setting}

We have come to the end of the educational program called KidQuest Club (Fitness, Food, and Fun). To evaluate the effectiveness of this program, we will be conducting a focus group session. The focus group session will be one hour in length and will ask you what you thought of KidQuest and what you have learned. You will be asked to do the following:

- Answer questions regarding the efficacy of the program. A copy of these questions can be requested by contacting the project director listed on this consent form.

There is no risk associated with this focus group session. The reason why we are doing this is to tell us what you learned and if we should do something different the next time we bring KidQuest into schools. Your parents will also be asked to give their permission for you to take part in this session. Please talk this over with your parents before you decide whether or not to participate. You do not have to participate if you do not want to. Your responses will be recorded in writing and audio to help us remember what was said. Since we will be asking you open-ended questions, we cannot guarantee participant confidentiality. Please only answer questions that you feel comfortable discussing. Names and identities will not be recorded. We may publish a summary of everybody's responses or present such a summary at a scientific meeting, but your identity and your responses would be totally confidential.

We will contact your parents via email to confirm your assent and your parent's consent for participation in the focus group session. In the email we will also ask you to provide a day and time that would work best for you. We will conduct the session at your school or at the University of Nebraska - Lincoln with time and location to be determined based on your feedback.

If you have any questions at any time, please ask one of the researchers.

Signature of Subject Date

Signature of Investigator Date

INVESTIGATOR

Wanda M. Koszewski, PhD, RD, LMNT

Phone: 402-472-7966

119A Ruth Leverton Hall, University of Nebraska-Lincoln, Lincoln, NE 68583-0806 


\section{Appendix J}

Youth Baseline Survey (Version 1) 


\section{Nebraskia Lincoln}

\section{Youth Survey}

\section{Subject ID Number}

Date

\begin{tabular}{|c|c|c|c|c|c|}
\hline \multicolumn{6}{|c|}{ Questions about yourself } \\
\hline 1. Are you a boy or a girl? & \multicolumn{5}{|l|}{ Oboy Ogirl } \\
\hline $\begin{array}{l}\text { 2. Month you were born? } \\
\text { (circle one) }\end{array}$ & \multicolumn{5}{|c|}{ Jan Feb March April May June July Aug Sept Oct Nov Dec } \\
\hline Date you were born? (circle one) & \multicolumn{5}{|c|}{$\begin{array}{llllllllllllllllllllll}1 & 2 & 3 & 4 & 5 & 6 & 7 & 8 & 9 & 10 & 11 & 12 & 13 & 14 & 15 & 16 & 17 & 18 & 19 & 20 & 21 & 22 \\
23 & 24 & 25 & 26 & 27 & 28 & 29 & 30 & 31\end{array}$} \\
\hline \multicolumn{6}{|l|}{ Write in the year you were born: } \\
\hline $\begin{array}{l}\text { 3. How do you describe yourself? } \\
\text { (select all that apply) }\end{array}$ & \multicolumn{5}{|c|}{$\begin{array}{l}\text { OWhite, not-Hispanic, not-Latino } \\
\text { OBlack or African American } \\
\text { OMexican American, Latino or Hispanic } \\
\text { OAmerican Indian } \\
\text { OAlaska Native } \\
\text { OAsian } \\
\text { OHawaiian or Pacific Islander } \\
\text { OTwo or more races } \\
\text { OOther }\end{array}$} \\
\hline \multicolumn{6}{|c|}{ Questions about the type of food eaten yesterday. } \\
\hline & & NONE & 1 TIME & 2 TIMES & 3 OR MORE TIMES \\
\hline \multicolumn{2}{|c|}{ 4. Yesterday, how many times did you drink milk? } & O & O & 0 & 0 \\
\hline \multicolumn{2}{|c|}{ 5. Yesterday, how many times did you eat cheese? } & 0 & 0 & 0 & 0 \\
\hline \multicolumn{2}{|c|}{$\begin{array}{l}\text { 6. Yesterday, how many times did you eat or drink } \\
\text { yogurt? }\end{array}$} & O & 0 & O & O \\
\hline \multicolumn{2}{|c|}{$\begin{array}{l}\text { 7. Yesterday, how many times did you eat fresh, } \\
\text { frozen, dried, or canned fruit? (do not count fruit juice) }\end{array}$} & O & 0 & O & O \\
\hline \multicolumn{2}{|c|}{$\begin{array}{l}\text { 8. Yesterday, how many times did you drink } 100 \% \\
\text { juice? }\end{array}$} & ○ & O & O & O \\
\hline \multicolumn{2}{|c|}{$\begin{array}{l}\text { 9. Yesterday, how many times did you eat fresh, } \\
\text { frozen, or canned vegetables? }\end{array}$} & ○ & O & 0 & 0 \\
\hline \multicolumn{2}{|c|}{$\begin{array}{l}\text { 10. Yesterday, how many times did you eat whole grain } \\
\text { cereal, whole grain bread, or whole grain crackers? } \\
\text { (where whole grain is the } 1^{\text {st }} \text { or } 2^{\text {nd }} \text { ingredient listed) }\end{array}$} & 0 & 0 & 0 & 0 \\
\hline
\end{tabular}




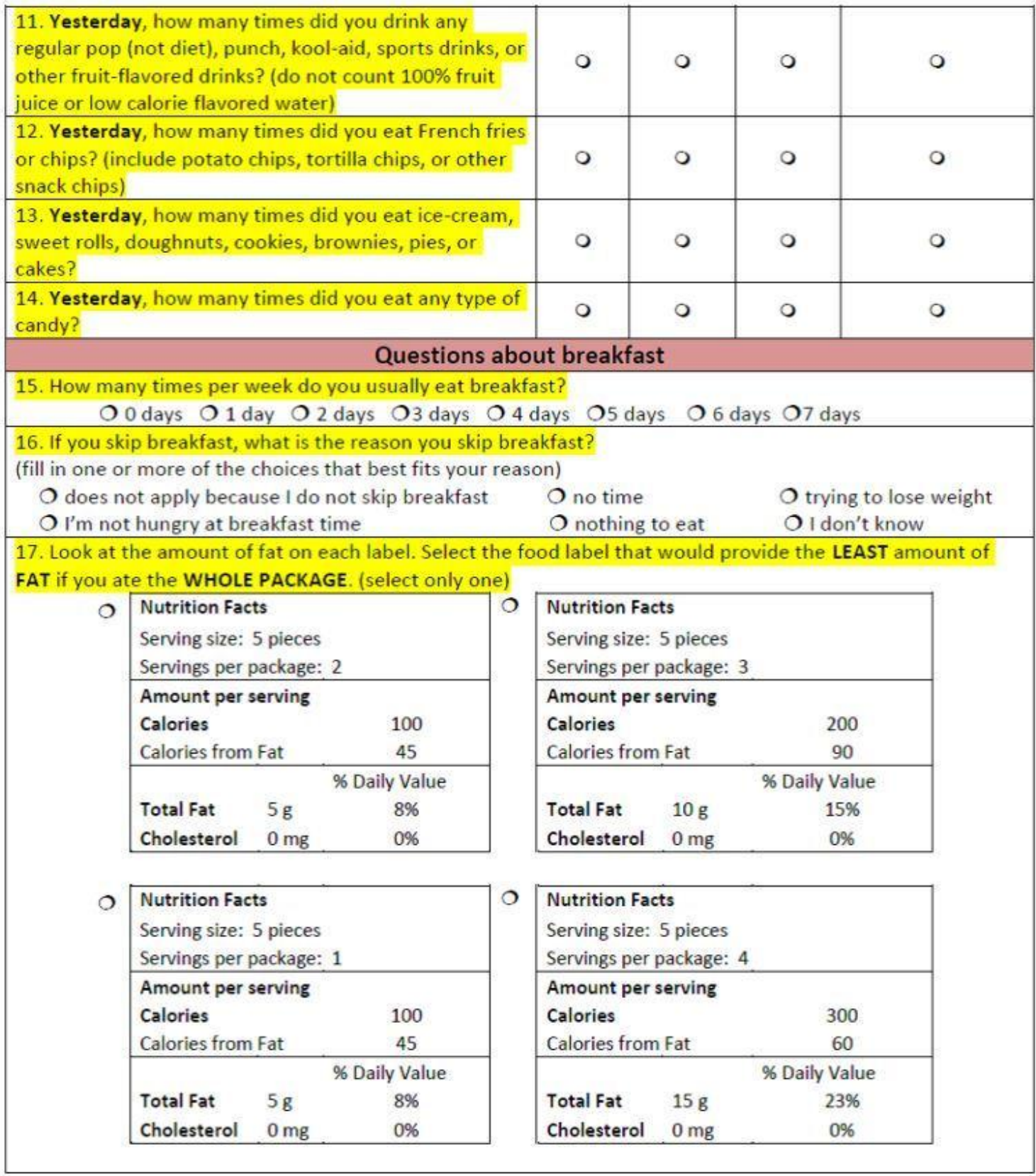


18. Look at the amount of sugar on each label. Select the food label that would provide the LEAST amount of SUGAR if you ate the WHOLE PACKAGE. (select only one)

\begin{tabular}{|c|c|c|}
\hline \multicolumn{3}{|c|}{$\begin{array}{l}\text { Serving size: } 12 \mathrm{oz} \\
\text { Servings per package: } 1\end{array}$} \\
\hline \multicolumn{3}{|c|}{ Amount per serving } \\
\hline Calories & & 152 \\
\hline Calories from $\mathrm{Fa}$ & & 0 \\
\hline & & \% Daily Value \\
\hline $\begin{array}{l}\text { Total } \\
\text { Carbohydrate }\end{array}$ & $38 \mathrm{~g}$ & $13 \%$ \\
\hline Dietary Fiber & $0 \mathrm{~g}$ & $0 \%$ \\
\hline Sugars & $38 \mathrm{~g}$ & \\
\hline
\end{tabular}

\begin{tabular}{|c|c|c|}
\hline $\begin{array}{l}\text { Nutrition Facts } \\
\text { Serving size: } 12 \\
\text { Servings per pad }\end{array}$ & ge: 2 & \\
\hline \multicolumn{3}{|c|}{ Amount per serving } \\
\hline Calories & & 152 \\
\hline \multicolumn{2}{|l|}{ Calories from Fat } & 0 \\
\hline & & \% Daily Value \\
\hline $\begin{array}{l}\text { Total } \\
\text { Carbohydrate }\end{array}$ & $38 \mathrm{~g}$ & $13 \%$ \\
\hline Dietary Fiber & $0 \mathrm{~g}$ & $0 \%$ \\
\hline Sugars & $38 \mathrm{~g}$ & \\
\hline
\end{tabular}

0 Nutrition Facts

Serving size: $12 \mathrm{oz}$

Servings per package: 2

Amount per serving

Calories

152

Calories from Fat

0

\begin{tabular}{llc|}
\hline Total & & \% Daily Value \\
Carbohydrate & $38 \mathrm{~g}$ & $13 \%$ \\
Dietary Fiber & $0 \mathrm{~g}$ & $0 \%$ \\
Sugars & $38 \mathrm{~g}$ & \\
\hline
\end{tabular}

\begin{tabular}{|c|c|c|}
\hline \multicolumn{3}{|c|}{$\begin{array}{l}\text { Nutrition Facts } \\
\text { Serving size: } 12 \mathrm{oz} \\
\text { Servings per package: } 4\end{array}$} \\
\hline \multicolumn{3}{|c|}{ Amount per serving } \\
\hline Calories & & 152 \\
\hline \multicolumn{2}{|c|}{ Calories from Fat } & 0 \\
\hline & & \% Daily Value \\
\hline \multicolumn{3}{|l|}{ Total } \\
\hline Dietary Fiber & $0 \mathrm{~g}$ & $0 \%$ \\
\hline Sugars & $38 \mathrm{~g}$ & \\
\hline
\end{tabular}

Questions about dietary guidelines and use of the food label.

19. How many total cups of fruits and vegetables combined should you eat each day?
Oless than 2 cups
$O$ at least 2 cups
$O$ at least 3 cups
$O$ at least 4 cups
O I don't know

20. From which food group should you eat the FEWEST servings each day?
breads, cereals, rice, pasta
O vegetables
$O$ fruits
o milk, yogurt, cheese
fats, oils, sweets
O I don't know

21. In the past week, have you used the Nutrition Facts food label to help you decide if the food you eat is a healthy choice or a food you should eat less of?
$O$ Yes
No
O Not Sure

\section{Questions about physical activity and screen time.}


22. In the past week, how many total minutes of physical activity have you usually done each day? (include any type of physical activity like walking, playing sports, riding bike, throwing frisbee, etc.)
0 Less than 30 minutes
O 30 to 45 minutes
O 1 hour or more

23. In the past week, how many hours per day have you usually spent on the computer away from school? (include time spent surfing the internet and instant messaging or texting on a cell phone)
O6 hours or more
O5 hours
O4 hours
O3 hours
O2 hours
O1 hour OLess than 1 hour

24. In the past week, how many hours per day have you usually spent watching TV or video movies away from school?

O6hours or more 05 hours 04 hours 03 hours 02 hours 01 hour OLess than 1 hour

25. In the past week, how many hours per day have you usually spent playing video games away from school? (don't include time you spend playing a physically active game like Dance Revolution ${ }^{\circ}$, Wii ${ }^{\circ}$ sports games or Wii Fit $\left.{ }^{\bullet}\right)$

O6hours or more 05 hours 04 hours 03 hours 02 hours 01 hour OLess than 1 hour

26. Do you have a TV in your bedroom?

O Yes O No

27. In the past week, how often have you done any physical activity with at least one other adult member of your household?
O 5 times or more
3 to 4 times
1 to 2 times
None

Questions about meal patterns.

28. How many meals have you eaten with at least one other member of your household in the past week? (include all mealtimes; breakfast, lunch and dinner)
O none
O 1 to 2
O 3 to 4
5 to 6
07 or more

29. How often in the past week has your family ordered a meal at a gas station store, mini-mart, fast food restaurant, sit down restaurant or take out/home delivery? (don't include school breakfast or school lunch) $\bigcirc$ none $\bigcirc$ to 2 times $\bigcirc 3$ to 4 times 05 to 6 times $\bigcirc 7$ or more times

30. During your most recent full week of school, how often did you eat the breakfast prepared by the school?

O 5 times $O 3$ to 4 times 01 to 2 times $O$ None

31. During your most recent full week of school, how often did you eat the lunch prepared by the school?
O 5 times
O 3 to 4 times
O 1 to 2 times
O None

32. During your most recent full week of school, how often did you bring your lunch from home?
O 5 times
3 to 4 times
O 1 to 2 times
O None

33. In the past week, how often have you talked with any member of your family about eating healthier foods?

O 5 times or more $\bigcirc 3$ to 4 times $O 1$ to 2 times $O$ None 


\section{Appendix K}

Youth Baseline Survey (Version 2) 


\section{YOUTH FOLLOWUP SURVEY}

\section{Nebrask}

Lincoln EXTENSION

This survey includes questions on various topics related to nutrition and physical activity. Each section starts with a header to identify the topic related to the questions.

Today's Date: $\underset{\text { Month }}{\square} / \underset{\text { Date }}{\bigsqcup_{\text {Year }}} / \underset{\square}{2 \underset{\square}{2}}$

\begin{tabular}{|c|c|c|c|c|}
\hline \multicolumn{5}{|l|}{ TYPE OF FOOD EATEN YESTERDAY } \\
\hline & None & $\begin{array}{c}1 \\
\text { Time }\end{array}$ & $\begin{array}{c}2 \\
\text { Times }\end{array}$ & $\begin{array}{l}3 \text { or More } \\
\text { Times }\end{array}$ \\
\hline 1. Yesterday, how many times did you drink milk, or eat yogurt or cheese? & 口 & $\square$ & $\square$ & $\square$ \\
\hline $\begin{array}{l}\text { 2. Yesterday, how many times did you eat fresh, frozen, dried, or canned fruit? } \\
\text { (do not count fruit juice) }\end{array}$ & 口 & 口 & 口 & 口 \\
\hline 3. Yesterday, how many times did you eat fresh, frozen, or canned vegetables? & 口 & 口 & 口 & $\square$ \\
\hline $\begin{array}{l}\text { 4. Yesterday, how many times did you eat whole grain cereal, whole grain bread, } \\
\text { or whole grain crackers? (where whole grain is the } 1 \text { st or } 2 \text { nd ingredient listed) }\end{array}$ & $\square$ & $\square$ & $\square$ & $\square$ \\
\hline $\begin{array}{l}\text { 5. Yesterday, how many times did you drink any regular pop (not diet), punch, } \\
\text { kool-aid, sports drinks, or other fruit-flavored drinks? (do not count } 100 \% \text { fruit } \\
\text { juice or low calorie flavored water) }\end{array}$ & $\square$ & $\square$ & $\square$ & $\square$ \\
\hline $\begin{array}{l}\text { 6. Yesterday, how many times did you eat french fries or chips? (include potato } \\
\text { chips, tortilla chips, or other snack chips) }\end{array}$ & $\square$ & $\square$ & $\square$ & $\square$ \\
\hline $\begin{array}{l}\text { 7. Yesterday, how many times did you eat ice-cream, sweet rolls, doughnuts, } \\
\text { cookies, brownies, pies, cakes or candy? }\end{array}$ & $\square$ & $\square$ & $\square$ & $\square$ \\
\hline
\end{tabular}

DIETARY GUIDELINES

8. How many total cups of fruits and vegetables combined

10. How many cups should you have from the milk group should you eat each day?
$\square$ less than 2 cups
$\square$ at least 2 cups
$\square$ at least 3 cups
$\square$ at least 4 cups
$\square$ I don't know

9. An example of a whole grain is:

$\square$ Oatmeal

$\square$ Tortilla chips

$\square$ Animal crackers

I don't know every day?
$\square 1$ cup
$\square 3$ cups
$\square 5$ cups
$\square$ I don't know

11. In the past week, have you used the Nutrition Facts food label to help you decide if the food you eat is a healthy choice or a food you should eat less of?
$\square$ Yes
$\square$ No
$\square$ Not Sure

12. Look at the amount of fat on each label. Select the food label that would provide the LEAST amount of FAT if you ate the WHOLE PACKAGE.

- Nutrition Facts Serving Per Cortainer. Amoum por Senving Calorles $100 \quad$ Calories fion Fat 45 Sonty Vuloe"

Total Fat 59 Cholesterol Ong

Nutrition Facts Serving Per Container 3 Anoun: Per Benving Calorles $200 \quad$ Calories from Fat 4 \begin{tabular}{lr}
\hline & NDaly Valices: \\
Total Fat $10 \mathrm{~g}$ & $16 \%$
\end{tabular} Cholestorol Omg

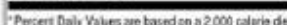

$\square$ Nutrition Facts Serving Size 5 pieces Aneunt for Bening Calories $100 \quad$ Calories lrom Fat 45 Solit Woumer

Total Fat $5 \mathrm{~g}$ Cholesterol Omg

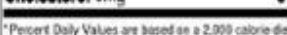

$\square$ Nutrition Facts Serving Sizo 5 piocoss Senving Per Senting Calories $300 \quad$ Calories from fat 60 Total Fat 159 soaly vileer Cholesterol Omg

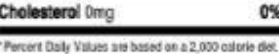


BREAKFAST

13. Eating breakfast in the morning will help you to do better in school.
$\square$ True
$\square$ False

14. In the past week, how many days did you eat breakfast?
$\square$ never
$\square 1$ day
$\square 2$ days
$\square 3$ days
$\square 4$ days
$\square 5$ days
$\square 6$ days
$\square 7$ days $\rightarrow$ Skip to question 16

15. What is the reason you skip breakfast? (Please select all that apply)

$\square$ No time to eat breakfast

$\square$ Trying to lose weight

$\square$ I am not hungry at breakfast time

$\square$ No food available to eat

$\square$ I do not like food that is available to eat

$\square$ Other (specify:

$\square$ I don't know

\section{ACTIVITIES}

16. In the past week, how often did you do any physical activity with at least one other adult member of your household?
$\square$ None
$\square 1$ to 2 times
$\square 3$ to 4 times
$\square 5$ times or more

17. In the past week, how many hours per day did you usually spent on the computer, watching T.V., or playing video games away from school?
$\square$ Less than 1 hour
$\square 1$ hour
$\square 2$ hours
$\square 3$ hours
$\square 4$ hours
$\square 5$ hours
$\square 6$ hours or more internet and instant messaging or texting on a cell phone, but don't include time playing a physically active game like Dance Revolution?, Wii? sports games or Wil Fit?

18. In the past week, how many total minutes of physical activity did you usually do each day?

$\square$ Less than 30 minutes include any type of

$\square 30$ to 60 minutes physical activity like

$\square$ More than one hour

walking, playing

sports, riding bike,

throwing frisbee, etc

19. Which of the following is an example of being physically active?

$\square$ Using the computer

$\square$ Riding a bike

$\square$ Watching TV

$\square$ Riding in a car

$\square$ I don't know

\begin{tabular}{|c|c|c|c|c|c|}
\hline \multicolumn{6}{|c|}{ QUESTIONS ABOUT HOW YOU FEEL } \\
\hline & $\begin{array}{l}\text { Not } \\
\text { Sure }\end{array}$ & $\begin{array}{c}\text { Not too } \\
\text { Sure }\end{array}$ & Sure & $\begin{array}{l}\text { Very } \\
\text { Sure }\end{array}$ & $\begin{array}{c}\text { Completely } \\
\text { Sure }\end{array}$ \\
\hline $\begin{array}{l}\text { 20. How sure are you that you can set goals for yourself to be more } \\
\text { physically active? (By 'physically active' we mean activities like } \\
\text { sports, active games, jogging, walking, swimming, biking and the like.) }\end{array}$ & $\square$ & ㅁ & ㅁ & 口 & 口 \\
\hline $\begin{array}{l}\text { 21. How sure are you that you can set physical activity goals for } \\
\text { yourself with little help from others? }\end{array}$ & $\square$ & 口 & 口 & $\square$ & $\square$ \\
\hline $\begin{array}{l}\text { 22. How sure are you that you can set goals for yourself to eat healthy } \\
\text { foods? (By 'healthy foods' we mean vegetables, fruits, low fat, high } \\
\text { fiber foods or snacks.) }\end{array}$ & $\square$ & $\square$ & $\square$ & $\square$ & $\square$ \\
\hline $\begin{array}{l}\text { 23. How sure are you that you can set healthy eating goals for } \\
\text { yourself with little help from others? }\end{array}$ & $\square$ & $\square$ & $\square$ & $\square$ & $\square$ \\
\hline
\end{tabular}




\section{MEALS \& ACTIVITIES WITH FAMILY}

24. In the past week, how often have you talked with any member of your family about eating healthier foods?

$\square$ None

$\square 1$ to 2 times

$\square 3$ to 4 times

$\square 5$ times or more

26. In the past week, how many days did you..

a. eat breakfast (morning meal) with at least one other member of vour household?

b. eat lunch (mid-day meal) with at least one other member of your household?

c. eat dinner/supper (evening meal) with at least one other member of your household?

\section{QUESTIONS ABOUT YOURSELF}

27. Are you a boy or girl?
$\square$ boy
$\square$ girl

28. Do you consider yourself to be Hispanic or Latino/Latina?
$\square$ yes
$\square$ no

29. How do you describe yourself? (Select all that apply)

$\square$ White (Caucasian)

$\square$ Black or African American

$\square$ Asian

American Indian or Alaska Native

$\square$ Native Hawaiian or Other Pacific Islander

$\square$ Other race(s), please specify:

30. What is your date of birth?

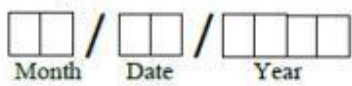

25. In the past week, how often have vou helped plan or cook any meals for you and/or your family?
$\square$ None
$\square 1$ to 2 times
प 3 to 4 times $\square 5$ times or more

\begin{tabular}{|c|c|c|c|c|}
\hline None & $\begin{array}{c}1 \text { to } 2 \\
\text { Days }\end{array}$ & $\begin{array}{c}3 \text { to } 4 \\
\text { Days }\end{array}$ & $\begin{array}{l}5 \text { to } 6 \\
\text { Days }\end{array}$ & Every Day \\
\hline$\square$ & $\square$ & $\square$ & $\square$ & $\square$ \\
\hline$\square$ & $\square$ & $\square$ & $\square$ & $\square$ \\
\hline$\square$ & $\square$ & $\square$ & $\square$ & $\square$ \\
\hline
\end{tabular}

29. In the past week, how many hours did you sleep per night on average?

$\square 4$ hours or less

$\square 5$ hours

$\square 6$ hours

$\square 7$ hours

$\square 8$ hours or more

$\square$ I don't know

32. How satisfied are you with your own weight?

$\square$ Very satisfied

$\square$ Somewhat satisfied

$\square$ Not very satisfied

$\square$ Not at all satisfied

33. Which statement best describes your own weight?

$\square$ Very underweight

$\square$ About right

$\square$ Overweight

$\square$ Obese (very overweight)

Thank you!

We greatly appreciate the time you have taken to complete this survey. 
Appendix L

Youth Follow-Up Survey 


\section{YOUTH FOLLOWUP SURVEY}

\section{Nebraskia \\ Lincoln EXTENSION}

This survey includes questions on various topics related to nutrition and physical activity. Each section starts with a header to identify the topic related to the questions.

Today's Date:

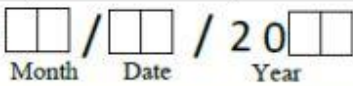

\begin{tabular}{|c|c|c|c|c|}
\hline \multicolumn{5}{|l|}{ TYPE OF FOOD EATEN YESTERDAY } \\
\hline & None & $\begin{array}{c}1 \\
\text { Time }\end{array}$ & $\begin{array}{c}2 \\
\text { Times }\end{array}$ & $\begin{array}{l}3 \text { or More } \\
\text { Times }\end{array}$ \\
\hline 1. Yesterday, how many times did you drink milk, or eat yogurt or cheese? & 口 & $\square$ & 口 & 口 \\
\hline $\begin{array}{l}\text { 2. Yesterday, how many times did you eat fresh, frozen, dried, or canned fruit? } \\
\text { (do not count fruit juice) }\end{array}$ & ㅁ & 口 & $\square$ & 口 \\
\hline 3. Yesterday, how many times did you eat fresh, frozen, or canned vegetables? & ㅁ & 口 & ㅁ & ㅁ \\
\hline $\begin{array}{l}\text { 4. Yesterday, how many times did you eat whole grain cereal, whole grain bread, } \\
\text { or whole grain crackers? (where whole grain is the } 1 \text { st or } 2 \text { nd ingredient listed) }\end{array}$ & $\square$ & ㅁ & ㅁ & ㅁ \\
\hline $\begin{array}{l}\text { 5. Yesterday, how many times did you drink any regular pop (not diet), punch, } \\
\text { kool-aid, sports drinks, or other fruit-flavored drinks? (do not count } 100 \% \text { fruit } \\
\text { juice or low calorie flavored water) }\end{array}$ & ㅁ & $\square$ & $\square$ & ㅁ \\
\hline $\begin{array}{l}\text { 6. Yesterday, how many times did you eat french fries or chips? (include potato } \\
\text { chips, tortilla chips, or other snack chips) }\end{array}$ & $\square$ & $\square$ & 口 & $\square$ \\
\hline $\begin{array}{l}\text { 7. Yesterday, how many times did you eat ice-cream, sweet rolls, doughnuts, } \\
\text { cookies, brownies, pies, cakes or candy? }\end{array}$ & $\square$ & $\square$ & $\square$ & $\square$ \\
\hline
\end{tabular}

DIETARY GUIDELINES

8. How many total cups of fruits and vegetables combined should you eat each day?

$\square$ less than 2 cups

$\square$ at least 2 cups

$\square$ at least 3 cups

$\square$ at least 4 cups

$\square$ I don't know

9. An example of a whole grain is:

$\square$ Oatmeal

$\square$ Tortilla chips

$\square$ Animal crackers

0. How many cups should you have from the milk group every day?
$\square 1$ cup
$\square 3$ cups
$\square 5$ cups
$\square$ I don't know

11. In the past week, have you used the Nutrition Facts food label to help you decide if the food you eat is a healthy choice or a food you should eat less of?
$\square$ Yes
$\square$ No
$\square$ Not Sure

12. Look at the amount of fat on each label. Select the food label that would provide the LEAST amount of FAT if you ate the WHOLE PACKAGE.

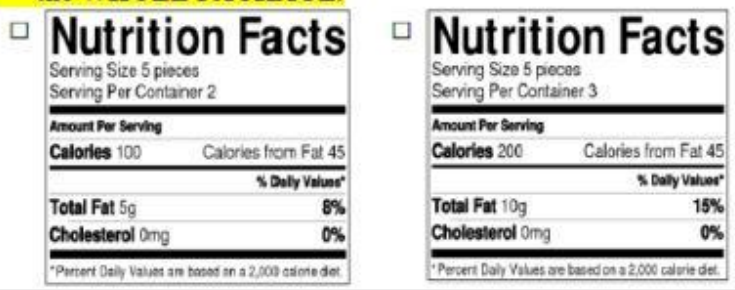

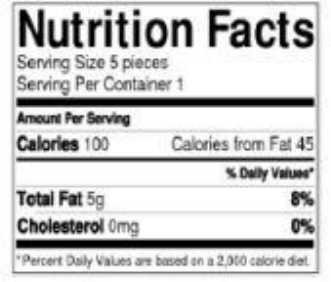

\begin{tabular}{|c|c|}
\hline \multicolumn{2}{|c|}{$\begin{array}{l}\text { Nutrition Facts } \\
\text { Senving Szeo } 5 \text { piocos } \\
\text { Senving Per Contianer } 4\end{array}$} \\
\hline Amount Pes Senting & \\
\hline Callories 300 & Calories trom Fat 60 \\
\hline & Solit vouver \\
\hline Total Fat 159 & $25 \%$ \\
\hline Cholestierol $0 \mathrm{mg}$ & ow \\
\hline
\end{tabular}




\section{BREAKFAST}

13. Eating breakfast in the morning will help you to do better in school.
$\square$ True
$\square$ False

14. In the past week, how many days did you eat breakfast?
$\square$ never
$\square 1$ day
$\square 2$ days
$\square 3$ days
$\square 4$ days
$\square 5$ days
$\square 6$ days
$\square 7$ days $\rightarrow$ Skip to question 16

15. What is the reason you skip breakfast? (Please select all that apply)

$\square$ No time to eat breakfast

$\square$ Trying to lose weight

$\square$ I am not hungry at breakfast time

$\square$ No food available to eat

$\square$ I do not like food that is available to eat

$\square$ Other (specify:

$\square$ I don't know

\section{ACTIVITIES}

\begin{tabular}{|}
$\begin{array}{l}\text { 16. In the past week, how } \\
\text { activity with at least on } \\
\text { household? } \\
\square \text { None } \\
\square 1 \text { to } 2 \text { times } \\
\square 3 \text { to } 4 \text { times } \\
\square 5 \text { times or more }\end{array}$
\end{tabular}

17. In the past week, how many hours per day did you usually spent on the computer, watching T.V., or playing video games away from school?
$\square$ Less than 1 hour
$\square 1$ hour
$\square 2$ hours
$\square 3$ hours
$\square 4$ hours
$\square 5$ hours
$\square 6$ hours or more

18. In the past week, how many total minutes of physical activity did you usually do each day?

\begin{tabular}{l|l}
$\square$ Less than 30 minutes & $\begin{array}{l}\text { include any type of } \\
\text { physical activity like } \\
\text { walking, playing } \\
\square 30 \text { to } 60 \text { minutes }\end{array}$ \\
$\square$ More than one hour & $\begin{array}{l}\text { sports, riding bike, } \\
\text { throwing frisbee, etc. }\end{array}$
\end{tabular}

19. Which of the following is an example of being physically active?

$\square$ Using the computer

$\square$ Riding a bike

$\square$ Watching TV

$\square$ Riding in a car

$\square$ I don't know

\begin{tabular}{|c|c|c|c|c|c|}
\hline \multicolumn{6}{|c|}{ QUESTIONS ABOUT HOWV YOU FEEL } \\
\hline & $\begin{array}{l}\text { Not } \\
\text { Sure }\end{array}$ & $\begin{array}{l}\text { Not too } \\
\text { Sure }\end{array}$ & Sure & $\begin{array}{l}\text { Very } \\
\text { Sure }\end{array}$ & $\begin{array}{l}\text { Completely } \\
\text { Sure }\end{array}$ \\
\hline $\begin{array}{l}\text { 20. How sure are you that you can set goals for yourself to be more } \\
\text { physically active? (By 'physically active' we mean activities like } \\
\text { sports, active games, jogging, walking, swimming, biking and the like.) }\end{array}$ & 口 & 口 & ㅁ & $\square$ & ㅁ \\
\hline $\begin{array}{l}\text { 21. How sure are you that you can set physical activity goals for } \\
\text { yourself with little help from others? }\end{array}$ & 口 & 口 & 口 & 口 & 口 \\
\hline $\begin{array}{l}\text { 22. How sure are you that you can set goals for yourself to eat healthy } \\
\text { foods? (By 'healthy foods' we mean vegetables, fruits, low fat, high } \\
\text { fiber foods or snacks.) }\end{array}$ & $\square$ & $\square$ & $\square$ & $\square$ & $\square$ \\
\hline $\begin{array}{l}\text { 23. How sure are you that you can set healthy eating goals for } \\
\text { yourself with little help from others? }\end{array}$ & $\square$ & 口 & ㅁ & ㅁ & $\square$ \\
\hline
\end{tabular}




\section{MEALS \& ACTIVITIES IVITH FAMILY}

24. In the past week, how often have you talked with any member of your family about eating healthier foods?
$\square$ None
$\square 1$ to 2 times
$\square 3$ to 4 times
$\square 5$ times or more

25. In the past week, how often have you helped plan or cook any meals for you and/or your family?
$\square$ None
$\square 1$ to 2 times
$\square 3$ to 4 times
प 5 times or more

\begin{tabular}{|l|c|c|c|c|c|}
\hline None & $\begin{array}{c}1 \text { to } 2 \\
\text { Days }\end{array}$ & $\begin{array}{c}3 \text { to } 4 \\
\text { Days }\end{array}$ & $\begin{array}{c}5 \text { to } 6 \\
\text { Days }\end{array}$ & Every Day \\
\hline of & $\square$ & $\square$ & $\square$ & $\square$ & $\square$ \\
\hline & $\square$ & $\square$ & $\square$ & $\square$ & $\square$ \\
\hline
\end{tabular}

QUESTIONS ABOUT YOURSELF

27. How satisfied are you with your own weight?
$\square$ Very satisfied
$\square$ Somewhat satisfied
$\square$ Not very satisfied
$\square$ Not at all satisfied

28. Which statement best describes your own weight?

$\square$ Very underweight

$\square$ About right

$\square$ Overweight

$\square$ Obese (very overweight)
29. In the past week, how many hours did you sleep per night on average?

$\square 4$ hours or less

$\square 5$ hours

$\square 6$ hours

$\square 7$ hours

$\square 8$ hours or more

$\square$ I don't know

\section{PROGRAM PARTICIPATION}

30. Overall, how satisfied were you with the program?
$\square$ Very satisfied
$\square$ Somewhat satisfied
$\square$ Not very satisfied
$\square$ Not at all satisfied

31. What would you suggest to make the KidQuest family activities more useful?

2. Please provide any comments or suggestions you have regarding the program.

Thank you!

We greatly appreciate the time you have taken to complete this survey. 
Appendix M

Focus Group/ Structured Interview Script 


\section{Focus Group Introduction}

Hello and thank you for taking time to share about your experience with KidQuest Nutrition Club. My name is Amy Wehbe and helping me is [name of Graduate Assistant]. We are nutrition graduate students from the University of Nebraska Lincoln. The reason we're meeting today is to talk about KidQuest, a program that you participated in during your afterschool program at Dawes Middle School. We will be asking you questions to help us evaluate the afterschool program. There are no right or wrong answers to the questions we are about to ask. We understand that each of you will have your own opinions and will answer questions differently; but please share exactly what you think. If for some reason you do not feel comfortable answering the questions, you do not have to share. You may also discuss the questions amongst each other. We are interested in what you have to say and are here to make sure each of you has a chance to speak. If one of you is talking too much, we may ask you to give the others a chance. If you are not talking much, we may call on you as we want to make sure everyone has an opportunity to share. [Name of Graduate Assistant] and I will both be taking notes and tape recording the session in order to help us remember what you said. No names will be recorded or used in any reports generated from this session.

To start off,

1. Please tell us your gender, age, and year in school.

2. Overall, what did you think of the KidQuest Club?

3. Think back to the first day of the club what all have you learned?

4. What did you think of the weekly lessons?

a. What, if anything did you learn?

i. Nutrition Label and Think Your Drink

ii. Portion Sizes, Snacks, and Eating Out

iii. Fruits and Vegetables

iv. Dairy

v. Media Messages

5. What did you think of the weekly Physical Activity time?

a. Which ones were your favorite activities?

b. Which ones were your least favorite activities?

c. Are there any activities you would have liked to do?

i. If so, what?

6. What did you think of the Family Fun Packs?

a. Did you go through the pack with your parents?

b. What, if anything did you learn from them?

c. Did your parents learn anything from them? 
7. What did you think of Cooking Club?

a. What were your favorite recipes?

b. What were your least favorite recipes?

c. Are there any recipes that you would have liked to make, but didn't?

8. Is there anything KidQuest did not teach you that you wish you would have learned?

a. If so, what?

9. Is there anything you think we could have done differently?

a. If so, what?

\section{Probe Questions:}

- Would you explain further?

- Would you give me an example of what you mean?

- Would you say more?

- Is there anything else?

- I don't understand.

\section{Ending Statements:}

Do you have any additional questions or comments about KidQuest Nutrition Club? Thank you for your participation in KidQuest taking time to share your feedback; we greatly appreciate it. If you would like more information about today's session, feel free to contact [name of School Contact Personal] who will notify me and make sure to get back to you. Thanks again, Amy and [name of Graduate Assistant]. 
Appendix N

KidQuest Nutrition Lessons (6 Lessons) 
Lesson 1: Introduction, Label Lingo, and Think Your Drink

\section{LESSON 1: INTRODUCTION, LABEL LINGO AND THINK YOUR DRINK}

\author{
Lesson Outline \\ $\Rightarrow$ Program overview. \\ $\Rightarrow$ Spot the Block Label Lingo and Think Your Drink \\ discussion. \\ $\Rightarrow$ Sugar Shocker Challenge activity. \\ $\Rightarrow$ Physical Activity Lesson (PAL).
}

\section{ACTIVITY OUTCOMES}

- Participants will be introduced to the main goals of the program and how it works.

- Participants will identify the basics of food label reading.

- Participants will be presented with a visual demonstration of the high amount of sugar and empty calories in popular sodas and sports drinks.

\section{Materials and Preparation}

$\square$ 1-2 weeks prior to lesson 1, provide the classroom teacher with the parent letter/ consent form. (See Evaluation Section) Note: consent required only if using surveys to measure program outcomes.

Copies of the pre nutrition survey. (See Evaluation Section) Note: the nutrition surveys are an optional component for programs planning to measure program outcomes.

Computer, projector and KidQuest CD with powerpoint lesson one or KidQuest Flipchart.

$\square$ Select the PAL and gather any materials required for the selected PAL. (See PAL Section)

$\square$ (Snack) Family Fun Pack participant copies. (See Family Fun Pack Section) Print front to back and staple.

Family Fun Pack prize box. (See Family Fun Pack Section)

$\square$ Family Fun Pack Quest Challenge/Feedback card collection folder. (See Family Fun Pack Section)
1-2 weeks prior to the lesson, explain the Family Fun Packs and how they work to the classroom teacher including the homework option. Provide the classroom teacher with a folder to collect the Quest Challenge/Feedback cards and the prize box. (See Family Fun Pack Section)

In advance collect containers of beverages; empty and rinse if desired to decrease weight of carrying materials.

$\square$ Note: the beverages are for demonstration only, not consumption. Total of 16 beverage containers needed for activity. Suggested types of beverages:

$.12 \mathrm{oz}$. can of soda (not diet)

-12 oz. can of soda (diet or reduced calorie)

-12 oz. can or bottle of fruit juice (not $100 \%$ fruit juice) -sports drinks (not reduced calorie) - sports drinks (reduced calorie) -flavored fitness water (not reduced calorie) - flavored fitness water (reduced calorie) - flavored water (reduced calorie) -plain water bottle •energy drinks 


\section{LESSON 1: CONTINUED}

\section{Materials and Preparation Continued}

$\square 4$ calculators.

4 notepads.

4 pencils.

4 boxes of sugar cubes.

16 clear plastic disposable cups.

4 plastic containers with lids (large enough to hold one box each of sugar cubes).

4 large 2 gallon or jumbo plastic sealable bags.

Assemble materials for Sugar Shocker Challenge activity to accommodate 4 group stations.

1. Empty each box of sugar cubes into a plastic container.

2. Fill each of the 4 jumbo bags with one each of the following:

-calculator

-notepad

-pencil

- box of sugar cubes

-4 clear plastic disposable cups

-4 different types of beverage containers. They should vary in the amount of sugar content and calories they contain.

\section{Set Up Notes}

- Collect parent letter/consent forms if utilizing the pre and post nutrition surveys.

- Prior to the lesson, ask the classroom teacher if the classroom's computer and projector can be used. If not, allow time to set up equipment being brought in or utilize the KidQuest Flipchart.

- Prior to starting the lesson if possible, set up 4 stations around the room with one of the Sugar Shocker Challenge Activity bags. 


\section{LESSON 1: POWERPOINT/FLIPCHART NOTES}

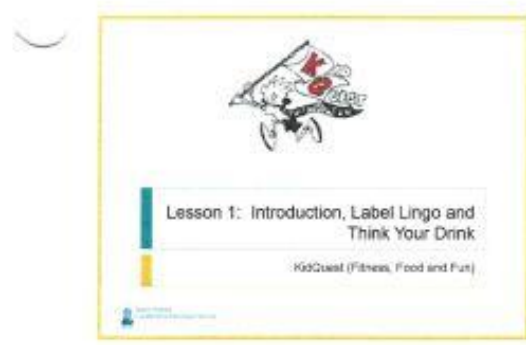

Introduce self and explain that KidQuest is a program designed especially for their age group to encourage healthy food and drink choices, moving more, and sitting less.

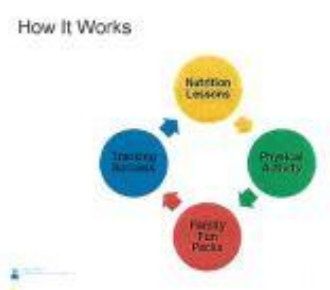

Explain that each session in the classroom will include a fun lesson on nutrition followed by a fun physical activity. Today our topic is on label reading and types of beverages.

We will also send home Family Fun Packs which include information on healthy eating, physical activity and recipes you can try. There are 4 different Family Fun Packs: Snacks, Meals, Activity and Screen Time. Today we will send home with each of you a Snack Pack. Using the Snack Pack copies; describe that the first part of the pack contains information for them to share with their parents on healthy snacking and the last part contains recipes they can try. Then using the attached Quest Challenge/Feedback sheet, explain to participants they can take the challenges listed and have their parents fill out the Feedback card and then bring this card back by (provide an established date prior to your next visit to do lesson two). They are to provide the Quest Challenge/Feedback sheet to their teacher who will collect them and then they will be eligible for a prize from the KidQuest prize box. Their classroom teacher will determine how the prizes will be distributed. Hand out the snack packs to participants. Remind participants that next time you will hand out the meal pack. Tracking success involves surveys and other measurements that might be taken. Explain any evaluation measures that will be conducted. (Note: there is a pre and post survey option that can be utilized. If using a pre survey, administer survey at this time in accordance with your institution's guidelines. (See Evaluation Section)

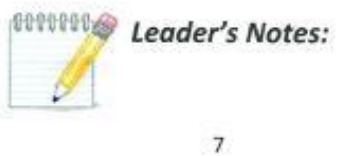




\section{LESSON 1: POWERPOINT/FLIPCHART NOTES}

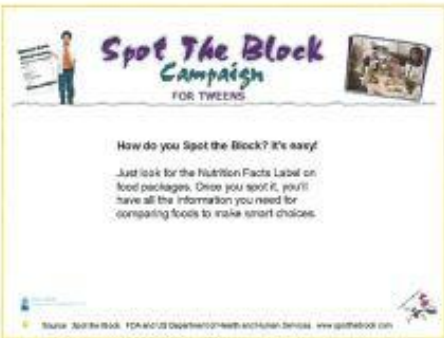

Label Know How with Spot the Block

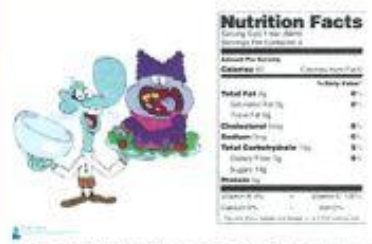

2
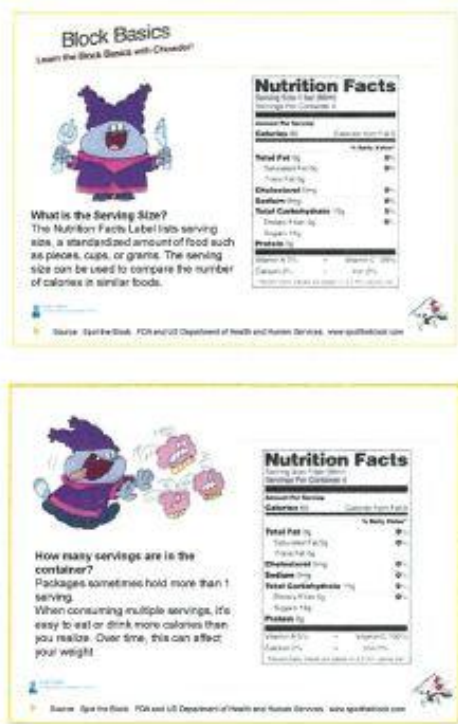

\&
Today, our lesson will focus on label reading and drink choices. First we will go through label reading using information from the Spot the Block Campaign for Tweens which will give us an overview of how to use the Nutrition Facts Label to make healthier food choices.

Ask participants, "How many of you have ever looked at the nutrition facts label on foods or drinks?"

The nutrition facts label can help us decide foods to eat more of and foods to eat less of. But first we need to learn some label know how and we will be doing that with the characters Mung and Chowder. See what the Nutrition Facts Label says about serving size and calories by asking yourself these questions: go to next slide.

Go through points on the slide.

Go through points on the slide. 


\section{LESSON 1: POWERPOINT/FLIPCHART NOTES}

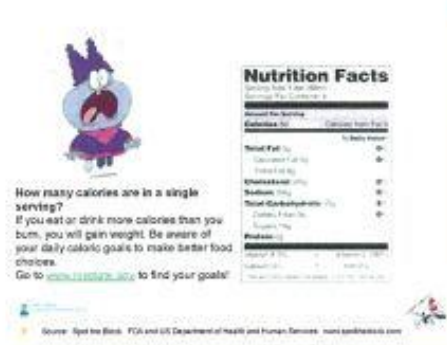

Add: everyone's calorie needs will vary. For youth in your age group you need around 2000 calories per day, more if you are active and less if you are not active.

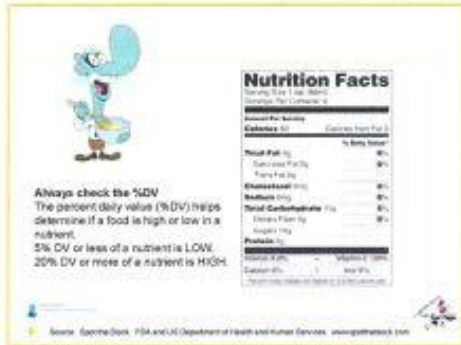

Go through points on the slide.

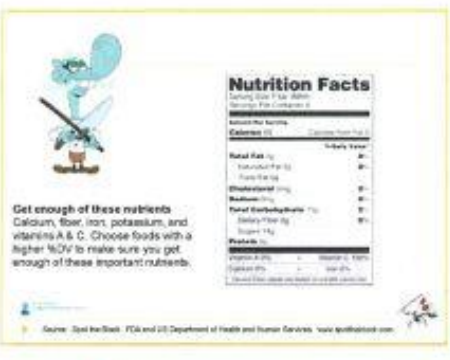

Go through points on the slide.

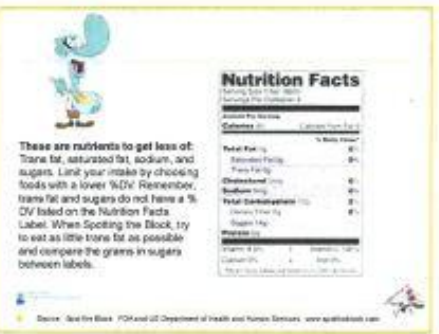

Go through points on the slide. Add - in a few minutes we will be comparing the sugar content of different drinks.

Leader's Notes: 


\section{LESSON 1: POWERPOINT/FLIPCHART NOTES}

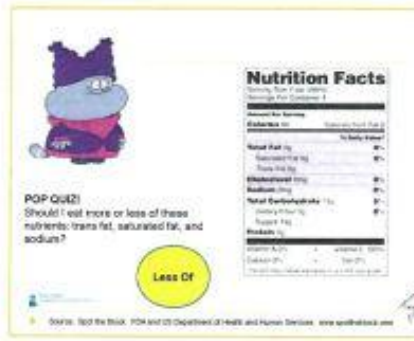

Click mouse to reveal the answer: Less of.

If using the KidQuest Flipchart, cover the answer with a sticky note.

$x^{2}$

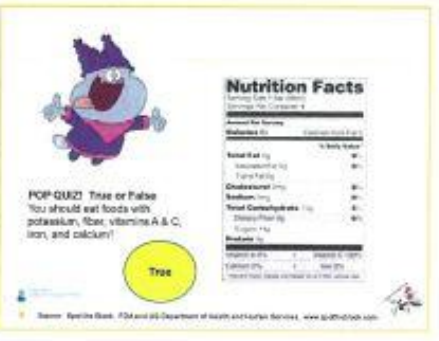

Click mouse to reveal the answer: True.

If using the KidQuest Flipchart, cover the answer with a sticky note.
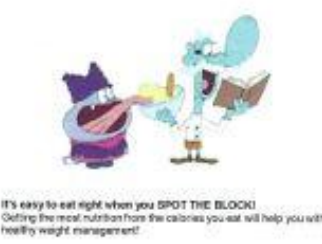

2

s

Almost all of the KidQuest lessons will include some label reading so you will have an opportunity to learn more and put your knowledge to practice.

Ask participants if they have any questions at this time about labels.

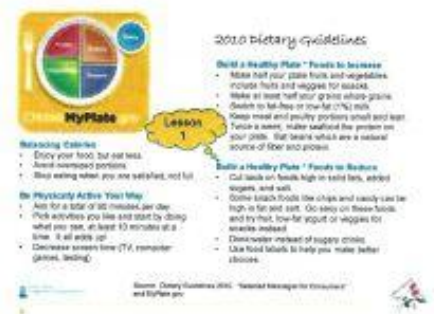

The rest of the lesson will focus on the sugars in some of the things we drink. MyPlate.gov and the 2010 Dietary Guidelines for Americans give us some recommendations for taking action which include: Balancing Calories (read points beneath this heading), Being Physically Active Your Way (read points beneath this heading), Building a Healthy Plate with Foods to Increase (we will talk more about this in future lessons) and Building a Healthy Plate with Foods to Reduce (our lesson today and activity we will be doing focuses on these tips especially in reading food labels for healthy choices and in decreasing the sugar we drink).

South Dakota

Cooperative Extension Service

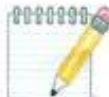

Leader's Notes: 


\section{LESSON 1: POWERPOINT/FLIPCHART NOTES}

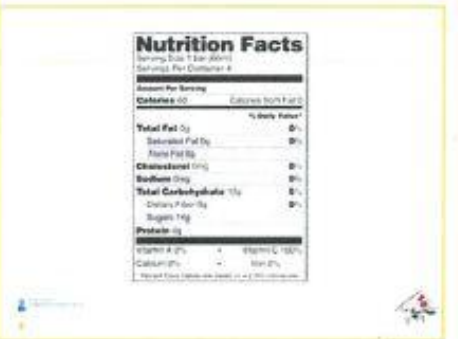

Sugar Shocker Challenge

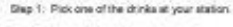

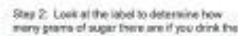
masing

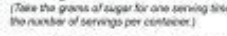

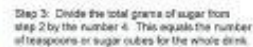

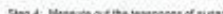

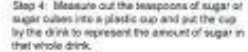

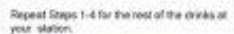

Healthier Drink Choices

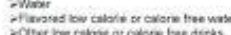

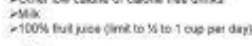
A note about milk:

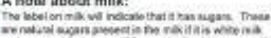

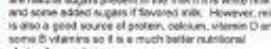
choca then aces Pep.

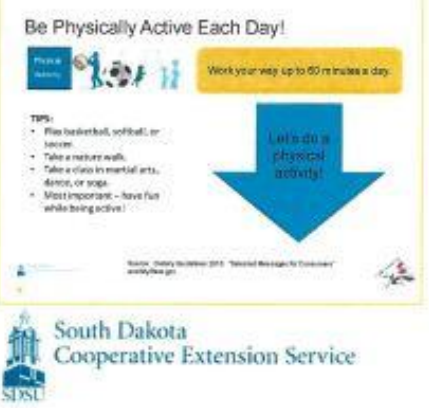

Point out the area on the label indicating the number of sugar grams per serving. Note that there is not a \%DV (daily value) for sugar. Explain that many drinks have more than one serving per container so they may need to multiply the grams of sugar for one serving by the number of servings in the whole container. Use the label as an example (If eating the whole container in this case the amount of sugar grams would be $14 \mathrm{~g} \mathrm{X} 4$ servings per container to $=56$ grams of sugar. That's quite a bit of added sugars!

Tell participants that next they will be working in groups to discover the amount of sugar in popular drinks. Explain they will be divided into 4 groups to take the Sugar Shocker Challenge.

Go through the instructions on the slide.

Number participants from 1 to 4 to form the 4 groups for the Sugar Shocker Challenge and direct each group to a station that was set up. As the groups are completing the challenge, visit each group to address any questions. Announce when 5 minutes are left before the activity needs to be completed.

Discuss some of the findings from the Sugar Shocker Challenge. Review healthier low sugar and calorie drinks on the slide.

Briefly cover some of the points on the slide, then start your selected PAL (Physical Activity Lesson).

Leader's Notes: 


\section{Lesson 2: Portion Sizes, Snacks, and Eating Out}

\section{LESSON 2: PORTION SIZES, SNACKS AND EATING OUT}

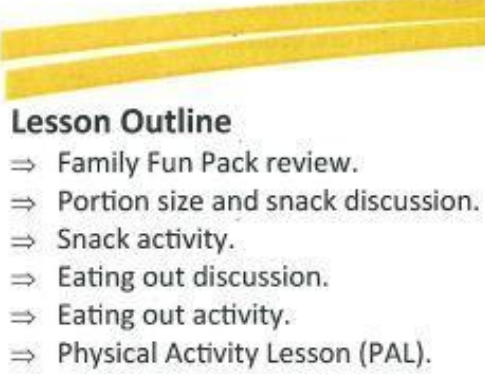

\section{Materials and Preparation}

Computer, projector and KidQuest CD with powerpoint lesson two or KidQuest Flipchart.

Select the PAL and gather any materials required for the selected PAL. (See PAL Section)

$\square$ (Meal) Family Fun Pack participant copies. (See Family Fun Pack Section) Print front to back and staple.

1 small (1 to 1.5$)$ serving bag of chips.

1 larger than the above bag of chips, same brand.

Variety of ready to eat snacks that would be considered "whoa" or "less of snacks". Generally snacks with more than $10 \%$ daily value for total fat and/or high in sugars (more than 15 grams per serving). Note: one of the "whoa" snacks will be put with a "go" snack in a bag so an equal number of "go" and "whoa" snacks will be needed to accommodate the number of participants. Suggested "whoa" snacks: -soda (not diet) tip: use soda container from lesson one

-snack size bag of chips (not the baked or reduced calorie variety).

\section{ACTIVITY OUTCOMES}

- Participants will be able to list a variety of healthier snacks.

- Participants will identify types of snacks to eat "more of" and "less of".

- Participants will discover the high fat and calorie content in some fast foods and be able to identify healthier options.
- candy bars and licorice -fruit snacks (not the reduced sugar variety) -cookie package

$\square$ Variety of ready to eat snacks that would be considered "go" or "more of snacks".

Suggested "go snacks":

-fruit and vegetable food models or pictures - lowfat granola or breakfast bars made with whole grains - lowfat yogurt container - lite or fat free microwave popcorn -reduced or lowfat crackers made with whole grains

$\square 1$ gallon size sealable bags (enough for each participant).

$\square 2$ medium sized plastic containers (1 marked "whoa" and 1 marked "go" snacks). Tip: small bathroom garbage containers (unused) work well. (See Activity Supplements Section)

$\square$ Packing tape.

1 copy of the Restaurant Title sheets for each restaurant. (See Activity Supplements Section) 


\section{LESSON 2: CONTINUED}

\section{Materials and Preparation Continued}

$\square 4$ one or half inch binders with a slip in cover.

- 1 copy each of the Restaurant's Nutrition Information sheets. (See Activity Supplements Section).

D 1 copy each of the Restaurant Activity sheets. (See Activity Supplements Section).

4 red plastic plates, at least 8 inches in diameter.

4 green plastic plates, at least 8 inches in diameter. Note: if green or red plate colors are unavailable, use other plate colors. It is helpful to have one color for the high fat menu choices and a different color for the healthier menu choices.

4 plastic butter knives.

4 calculators.

4 pencils.

At least 8 sheets of paper towels or napkins.

2 packages ( 8 sticks) of butter or margarine. Tip: Keep the sticks frozen until just before the lesson.

Assemble materials for the snack activity to accommodate 1 bag per participant:

1. Using the gallon size sealable bags, place one "whoa" snack and one "go" snack in each bag. Continue until there are enough bags prepared for each participant.

2. With packing tape, adhere the "whoa" label to one of the plastic containers and the "go" label to the other container.

South Dakota Cooperative Extension Service
Assemble materials for the Eating Out activity to accommodate 4 different groups:

1. Put one of the Restaurant Title sheets into one of the binders front slip cover and continue doing the same with the remaining Restaurant Title Sheets. You should end up with 4 binders, each with a different Restaurant Title sheet.

2. Then, 3-hole punch the Restaurant Nutrition Information and put in the corresponding binder with the Restaurant Title. Tip: If available, use slip covers to avoid damage to the sheets of paper with multiple uses.

3. Cut the Restaurant Activity Sheets in a circular shape to fit on the plates.

4. Attach the higher fat Restaurant Activity Sheets to the red plates. Tip: masking tape works well for attaching the plates.

5. Proceed by attaching the healthier choice Restaurant Activity Sheets to the green plates.

\section{Set Up Notes}

- Prior to the lesson, ask the classroom teacher if the classroom's computer and projector can be used. If not, allow time to set up equipment being brought in or utilize the KidQuest Flipchart.

- Prior to starting the lesson if possible, set up 4 stations around the room for the Eating Out Activity. Each station should have:

-1 of the restaurant binders

- 1 red and 1 green plate that go with the named restaurant binder

-1 calculator

-1 pencil

-1 butter knife

-2 paper towels 


\section{LESSON 2: POWERPOINT/FLIPCHART NOTES}

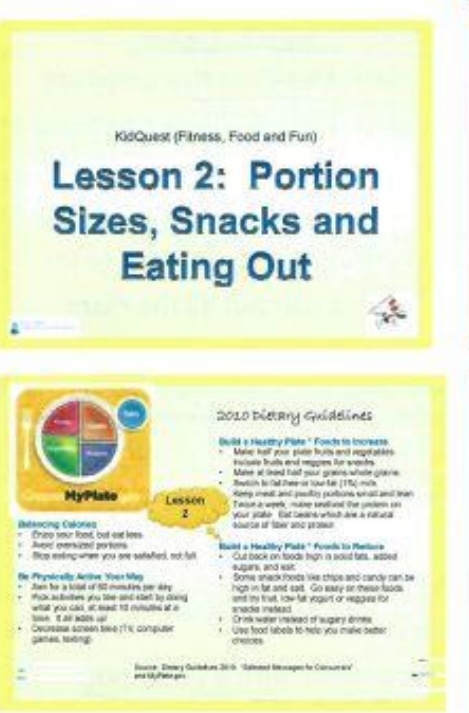

Portion Control

Bigger portions of food end drinks are everywhere! Stucies show that we eat more when provided a bigger portion.

Portion Size vs Serving Size:

soming size - standard unt of messuring foods portion size - what you actusily eat of a food item. often moro than 1 saving sia in the portions or

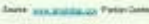

4

\section{Large Package Alert!}

-It's gone before you know it!

Do you know how many servings are in some packages?

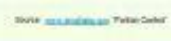

i
Explain to the group that the topic today is, "Portion Sizes, Eating

Out and Snacks." In this activity we will be looking at healthy andnot so healthy options when eating out and when choosing snacks. Hand out the Meal Family Fun Packs. Encourage participants to take the Quest Challenges for this Meal pack and tell them the due date for completion. Ask participants if they have any questions about the Family Fun Packs.

The Dietary Guidelines give us tips to Build a Healthy Plate by reducing foods that are high in fat, sugar and salt. Some of the more popular snacks you see in vending machines, at convenience stores and concession stands are high in fat, sugar, and/or salt. It's ok to have these foods once in a while for a treat but making those choices a common practice can leave you with eating more calories than you need from food sources that don't give you a lot of nutrition for living a healthy and active life. Our lesson today focuses on choices we make when eating snacks and when eating out.

We see bigger portions everywhere - at the grocery store, convenience store, movies, and when eating out. Studies show that we eat more if we are provided a bigger portion. For instance - if we are provided with a portion of chips in a small bowl vs. a bag of chips - we are more likely to eat more chips if provided the bigger bag. There is a big difference between serving size and portion size or what we actually eat. Read points on the slide.

How many times have you sat down to watch a TV program or play on the computer with a medium to large size snack of some kind and before you even knew what happened the snack was gone! Not because your brother or sister took it - but because you ate it!! Ask participants, do you ever look at how many servings are in some of the typical snack packages you might buy?

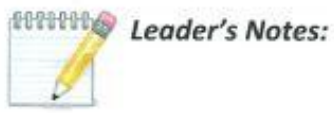




\section{LESSON 2: POWERPOINT/FLIPCHART NOTES}

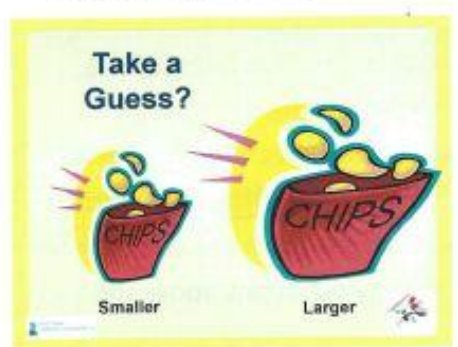

Portion Balancing Act

20 years

ago Now

- Whit. Difference $=$

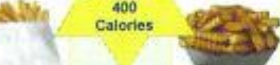

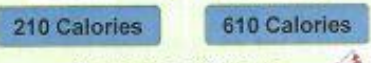
ton

2

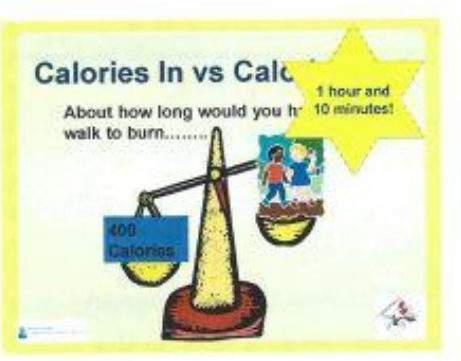

\section{Snacks}

Heathy snacks are a noma part of a healthy diet for growing kids

Heathy snacks can give you extra energy to play and grow.

High fat and sugar snacks like chips, canoy and pop can be unhealthy if you eat too much of them.

South Dakota

Cooperative Extension Service
Using a small and larger bag of chips - ask participants how many servings, calories, fat grams, etc. are in each. Point out that chips are an ok sometimes snack but how it's important to control the portions. Suggest that the next time they eat chips, to put a small portion from a larger bag into a small bowl then close up the large bag and put it away. If they are still hungry after the small bowl of chips then go for some fresh fruit or veggies to help fill them up without all the extra calories, fat, and salt.

20 years ago the average portion of fries looked like the picture on the left, now the average portion of fries looks much bigger. How many calories do you think the smaller fry has? How many calories do you think are in the larger serving size. Allow a small amount of time for responses before clicking on the answers.

If using the KidQuest Flipchart, cover the answer with a sticky note.

Allow a few participant guesses, then click for the answers.

If using the KidQuest Flipchart, cover the answer with a sticky note.

Ask participants, "How many of you snack?"

Go through points on the slide.

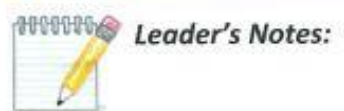




\section{LESSON 2: POWERPOINT/FLIPCHART NOTES}
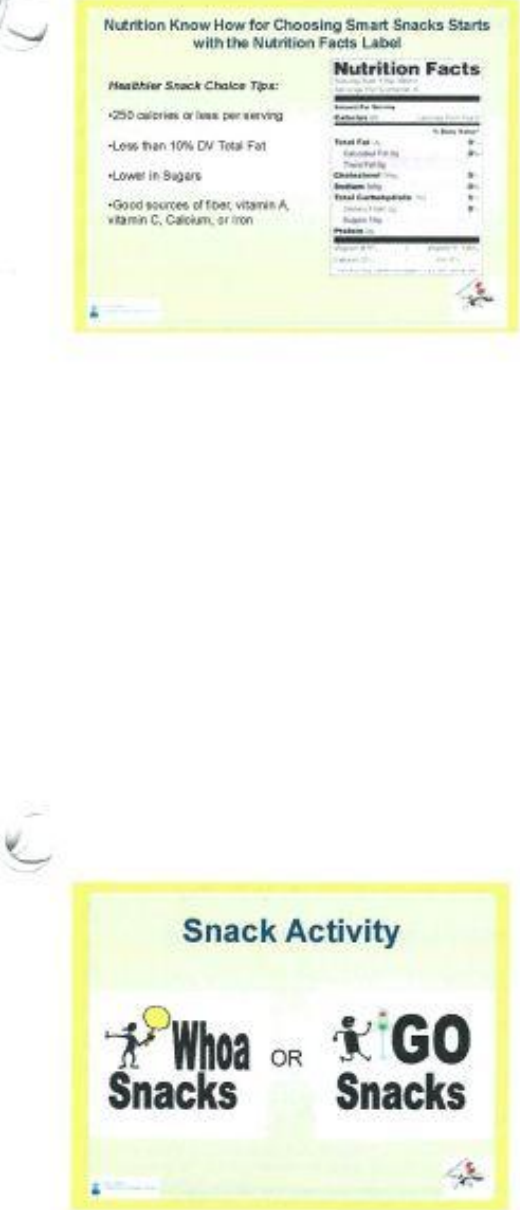

South Dakota

Cooperative Extension Service
Review the following key components of the food label:

-Ingredient list - the ingredients are listed from the most to the least in order.

- Serving size - the food label is based on 1 serving. Many packages have more than 1 serving size so if you eat the whole package you need to multiply the information for one serving by how many servings there are per package.

- Servings per container - this is how many servings there are for the whole package.

- Gram and milligram information - the amount in 1 serving. -\% Daily Values (DV) - provides a percentage of how much 1 serving has compared to what we need in a day.

-Key points - 20\% DV means the product is high in that nutrient and $5 \% \mathrm{DV}$ means it is low in that particular nutrient. When choosing snacks aim for snacks with less than $10 \%$ DV for total fat. There is no \% DV for sugar, so you need to compare products and pick versions with less grams of sugar. $15 \mathrm{~g}$ of sugar or less is considered lower in sugar.

Start the snack activity by instructing participants to grab one of the snack bags and to begin looking at the nutrition facts label. Explain that each snack bag contains 1 "whoa" snack and 1 "go" snack. Also remind participants that they won't be eating any of these snacks, they are for demonstration purposes only. Explain to participants that they will line up and use the food label and other knowledge they have gained to decide which snack in their bag is a "whoa" or "go" snack and then shoot that snack into the bucket. Have participants form a line. As participants are making their decisions about which bucket their snack goes in, guide participants in checking for the \%DV for fat and the sugar grams information as described in the previous slide notes.

P0000008 Leader's Notes: 


\section{LESSON 2: POWERPOINT/FLIPCHART NOTES}

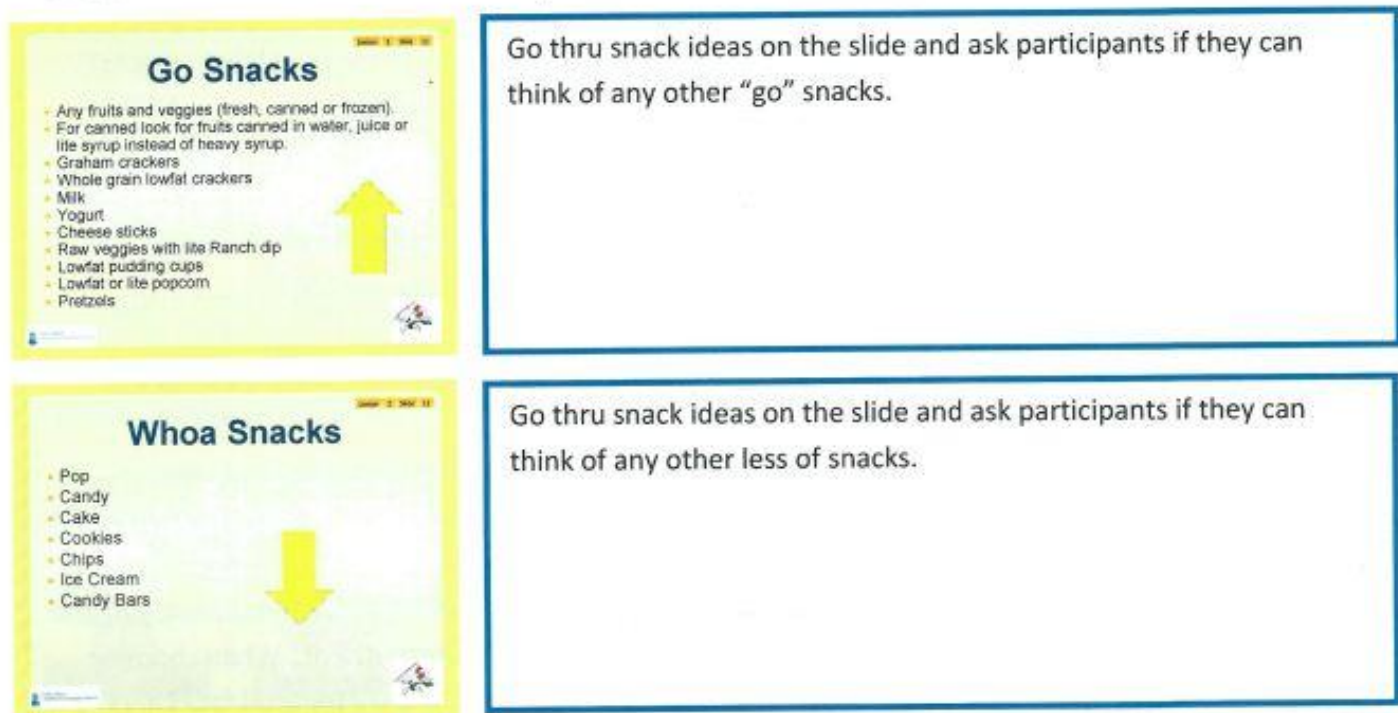

Eating Out

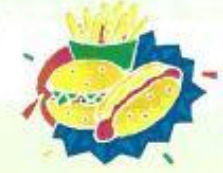

sit

Explain to participants that the next part of the lesson will focus on eating out.

Ask participants, "Do you ever eat out at fast food restaurants?" Explain: a lot of people eat out because it's quick. Many of the foods at fast food restaurants serve really large portions and are high in fat and calories. This is fine once in awhile but if you eat out a lot, all the extra fat and calories can lead to an unhealthy diet. There are healthier choices you can make when eating out and many restaurants are getting better at providing healthier options.

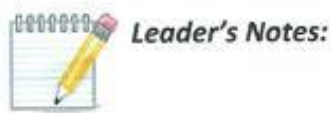




\section{LESSON 2: POWERPOINT/FLIPCHART NOTES}

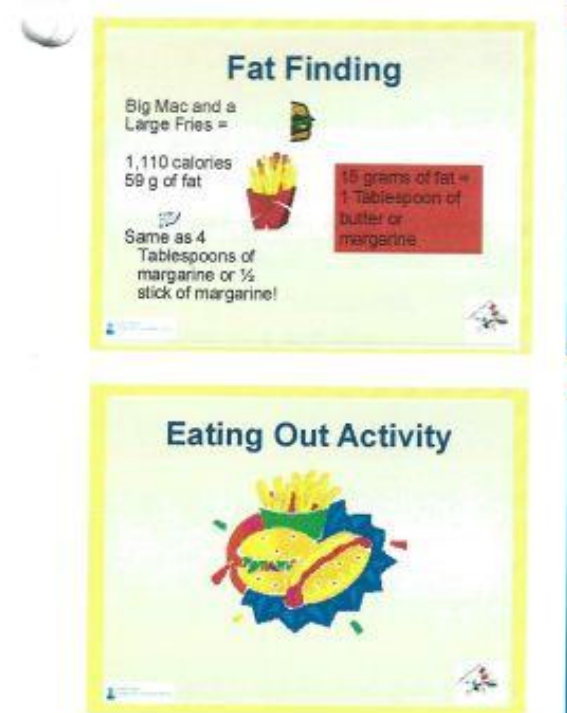

\section{Healthier Choices}

summarize the following about choosing hesittiver Generally the grilid chicken and plain namburger or civeseburger are ok optians
Sub type of sandwiches witheut mayo are also good Sub type of sandwiches without mayo ars also geod
choices If getting tries onder the smsi instadd of laros. Order small drinks instegd of lasge. Bentar yet. order milk or water.

with your sentaich of sces of that instead of fries

2

Be Physically Active Each Day!

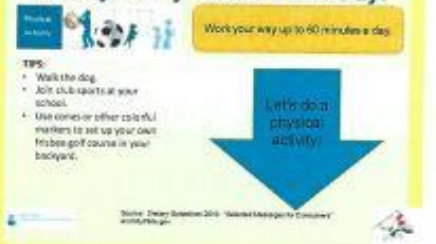

South Dakota

Cooperative Extension Service
Demonstrate the amount of fat in a Big Mac and Large fries by

reviewing the points on the slide.

Divide the participants into 4 groups and direct them to one of the 4 restaurant stations set up.

Instruct the groups to look up the items on their red plate first and calculate the amount of margarine that goes on the red plate.

Then instruct the groups to work on the instructions on their green plate. Also ask the groups to locate the menu item in their restaurant that has the highest calories.

When the activity is complete, summarize some of the groups findings and have each group share their highest calorie menu item. Tip: Ask the teacher if she would like to keep the plates to show other students or teachers.

Go through the points on the slide.

Briefly cover some of the points on the slide, then start your selected PAL (Physical Activity Lesson).

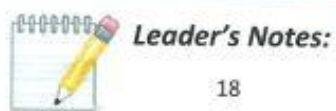


Lesson 3: Fruits and Veggies

LESSON 3: FRUITS AND VEGGIES

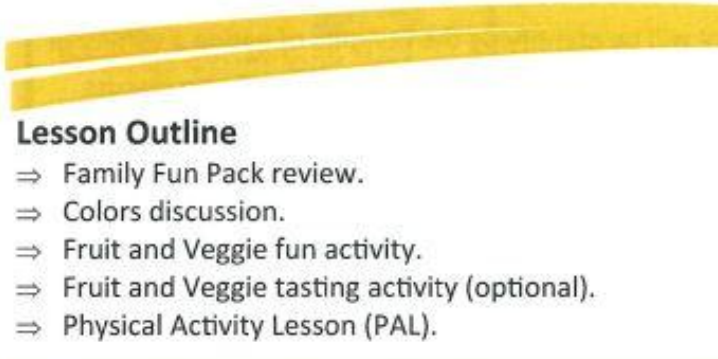

Materials and Preparation

$\square$ Computer, projector, KidQuest CD with powerpoint lesson three.

Select the PAL and gather any materials required for the selected PAL. (See PAL Section)

Participant copies of the Activity Family Fun Pack. (See Family Fun Pack Section) Print front to back and staple.

Food models of the following if available:

1 medium piece of fruit

$1 / 2$ cup of fruit

$1 / 2$ cup of vegetable

1 cup of vegetable

$1 / 4$ cup dried fruit

1 beach ball preferably with fruit and veggie color groups on the ball (red, blue/purple, orange/yellow, green, white).

CD player or ability to utilize classroom or personal computer with speakers.

Appropriate music for youth 10-12 yrs of age.

Source for Fruit and Veggie Fun Cards: www.fruitsandveggiesmatter.gov

South Dakota

(. Cooperative Extension Service

\section{ACTIVITY OUTCOMES}

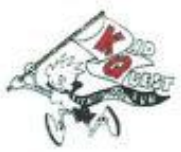

- Participants will be able to list at least 2 reasons why it's important to eat of fruits and veggies every day from a variety of sources and colors.

- Participants will identify ways to include more fruits and veggies in their day.

1 set of the Fruit and Veggie Color Fun cards. (See Activity Supplements Section) Print front to back.

Optional: if feasible, fruits and veggies for participants to sample. Select a variety of different colors.

If tasting-plastic or paper cups or bowls for each participant, forks and napkins.

If feasible-small nonfood incentive items for the fruit and veggie color fun activity game. Tip: many items can be ordered thru: www.pbhcatalog.com

\section{Set Up Notes}

- Prior to the lesson, ask the classroom teacher if the classroom's computer and projector can be used. If not, allow time to set up equipment being brought in or use the KidQuest flipchart.

- If the optional fruit and veggie tasting activity is planned: wash and cut the fruit and veggies and put in containers prior to the lesson. Prior to the lesson, contact the classroom teacher and ask if any of the participants have a food allergy. If a food allergy is present, do not include that food in the sampling.

- If possible-print the Fruit and Veggie Color Fun cards on cardstock, laminate and cut. 


\section{LESSON 3: POWERPOINT/FLIPCHART NOTES}

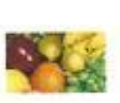

Lesson 3: Fruits and Veggies

KidQuest (Fitness, Food and Fun)

2
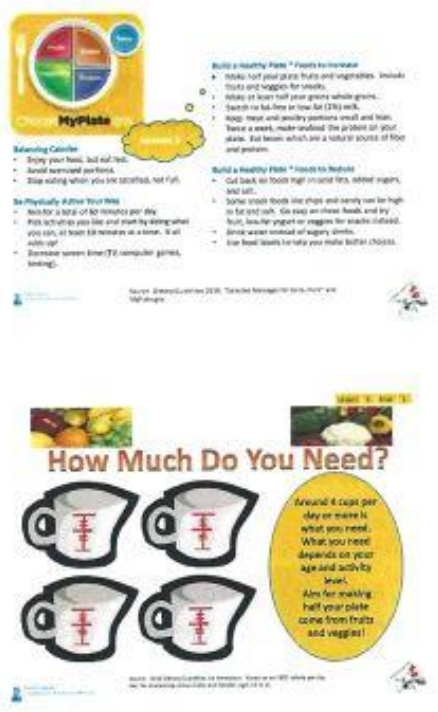

South Dakota Cooperative Extension Service
The Dietary Guidelines give us tips to Build a Healthy Plate by increasing certain food groups like fruits and veggies, whole grains and lowfat dairy. Our lesson today focuses on ways to include more fruits and veggies in our day from a wide variety of sources. The key message is to, "Make half your plate fruits and vegetables."

The amount of fruits and vegetables recommended each day depends on your age and activity level. For most boys and girls in your age group, around 4 cups total or more is recommended daily. Demonstrate what a cup and $1 / 2$ cup looks like with food models if available. This recommendation might be more if you are very active and increases as you get older. That may sound like a lot but it really isn't if you make fruits and veggies part of each meal and snack. If available, use food models to demonstrate how much one day of recommended fruit and veggie intake looks like. Point out: many children and adults are far from getting in the recommended fruits and veggies. The main key is to "make half your plate fruits and veggies" and to try and eat fruits and veggies from a wide range of sources and colors. So if all you ever eat for vegetables is corn and potatoes - it's time to expand your colors!

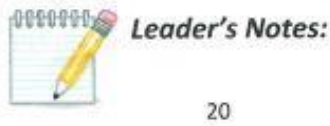




\section{LESSON 3: POWERPOINT/FLIPCHART NOTES}
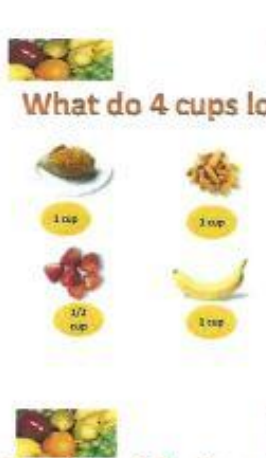

Benefits of Frults and Veggies

A Low in calories and fat

A High in vitamins, minerals and fiber.

A Reduce risk of disease.

Aun to eat and they taste great!

27

4

\section{*as}

Tips for eating more each day:

- Grab a piece of fruit with your breakdast. -Pack an apple, tanana or dried truit snack to much on

-Eat vegeses and fruit 3 your sthool hunch and supper mes at home.

shack on taby carrots far a quick low cal snack. Ask your parents to have plenty of fruts and vegsies wat tie on tard at home

2

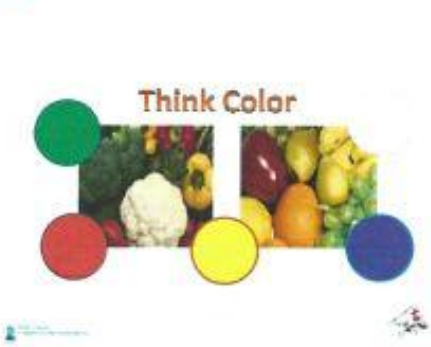

This amount doesn't look like it would be too hard to eat in 1 day!

Point out the benefits of fruits and veggies: low in calories and fat, high in vitamins, minerals, and fiber, help reduce risk of diseases, fun to eat and they taste great!

Ask participants to offer ideas on how they could get in the recommended cups of fruits and veggies each day.

Go thru tips on the slide if not already mentioned by participants.

Using the Eat a Colorful Variety of Fruits and Veggies Everyday slide, explain that different colors provide us with different types of vitamins, minerals and phytochemicals to help prevent diseases. Go thru each of the main colors (green, red, orange/yellow, blue/purple, white/brown) and ask participants to name their favorites for each color. Encourage participants to try a fruit or veggie they have never tried before.

\section{Leader's Notes:}




\section{LESSON 3: POWERPOINT/FLIPCHART NOTES}

Arrange participants in their desks, chairs or sitting on the floor in a
way that they will be able to hand the beach ball from one person to
the next.

-ross.

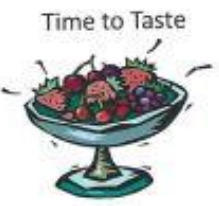

s.

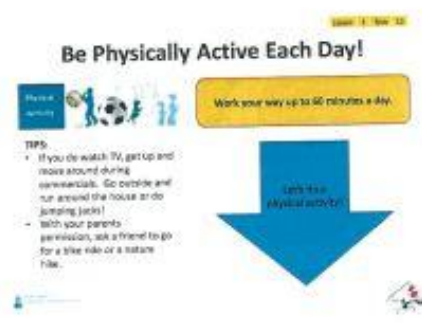

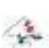

Skip this slide if not tasting fruits and veggies.

Explain to participant that now they will get to taste a variety of fruits and veggies from the different color groups (green, white, blue/ purple, red, orange/yellow). Remind the group that if anyone has a food allergy - they should talk to you before sampling the foods. Have participants wash hands before sampling food.

While participants are eating, ask if they have previously tried all the fruits and/or veggies being sampled.

Briefly cover some of the points on the slide, then start your selected PAL (Physical Activity Lesson).

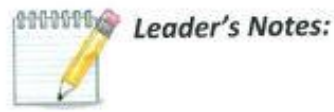


Lesson 4: Grains and Breakfast

LESSON 4: GRAINS AND BREAKFAST

\begin{tabular}{ll}
\hline Lesson Outline & ACTIVITY OUTCOMES \\
$\Rightarrow$ Family Fun Pack review. & Participants will be able to list at least 2 benefits \\
$\Rightarrow$ Grains and breakfast discussion. & of eating breakfast. \\
$\Rightarrow$ Grains and breakfast challenge activity. & Participants will be able to identify whole grain \\
$\Rightarrow$ Physical Activity Lesson (PAL). & products. \\
& Participants will be able to read the food label \\
& and identify whole grain and high fiber choices.
\end{tabular}

\section{Materials and Preparation}

$\square$ Computer, projector, and KidQuest CD with powerpoint lesson four or KidQuest Flipchart.

$\square$ Select the PAL and gather any materials required for the selected PAL. (See PAL Section)

$\square$ Participant copies of the Screen Family Fun Pack. (See Family Fun Pack Section) Print front to back and staple.

1 copy each of the following posters:

(See Activity Supplements Section)

- Name That Grain

- Breakfast Choices

-Is It a Whole Grain?

- Think Tank

4 copies each of the Grains \& Breakfast Team Challenge Activity sheets: (See Activity Supplements Section).

-Name That Grain

-Breakfast Choices

-Is It a Whole Grain?

-Think Tank

Masking tape.

South Dakota

Cooperative Extension Service $\square 4$ to 5 ( 2 gallon if available) plastic sealable bags or 6 to 8 ( 1 gallon) plastic sealable bags.

\section{Name That Grain Activity Items}

$\square$ Approximately $1 / 4$ to 1 cup each of the following whole grains: brown rice, popcorn, oatmeal, whole flaxseed, whole wheat.

5 quart size plastic sealable bags.

Permanent marker.

\section{Is It a Whole Grain? Activity Items}

$\square$ Collect boxes and labels in advance from 6 different types of foods made with grains for the "Is It a Whole Grain?" team challenge.

Suggestions as follows:

- Cereal made with whole grains as the 1st ingredient on the ingredient list. - Cereal made with whole grains as the $2 \mathrm{nd}$ or 3 rd ingredient on the ingredient list.

- Cereal not made with whole grains.

-Microwave popcorn.

-Pasta

- Granola or cereal bars made with whole grains. - Granola or cereal bars not made with whole grains.

- Bread made with whole grains.

-Wheat bread not made with whole grains.

- Crackers made with whole grains.

- Crackers not made with whole grains. 


\section{LESSON 4: CONTINUED}

\section{Materials and Preparation Continued}

\section{Breakfast Choices Activity Items}

$\square$ Collect boxes and labels in advance for 3 different types of breakfast foods made with grains for the Breakfast Choices team challenge. Suggestions;

- Cereal not made with whole grains and with greater than 10 grams of sugar per serving.

- Cereal made with whole grains with $10 \mathrm{~g}$ of sugar or less per serving.

- Poptarts.

- Granola bars made with whole grains.

Assemble the copies of the Grains \& Breakfast Team Challenge Sheets in the following order and staple each set: (Note-each set has one copy each of the different activity sheets.)

Set 1: Name That Grain, Breakfast Choices, Is It a Whole Grain?, Think Tank

Set 2: Breakfast Choices, Is It a Whole Grain?, Think Tank, Name That Grain

Set 3: Is It a Whole grain?, Think Tank, Name That Grain, Breakfast Choices

Set 4: Think Tank, Name That Grain, Breakfast

Choices, Is It a Whole Grain?

\section{Name That Grain Activity Assembly}

$\square$ Put each of the whole grains in one of the quart sized bags (do not mix the grains).

Using a permanent marker, label each of the bags with the letter only that corresponds to the grain in the bag as follows:

A-brown rice

B-popcorn

C-oatmeal

D-whole flaxseed

E-whole wheat

(Note: do not put the name of the grain on

the bag as the participants will be naming

the grain as part of the activity).
Is It a Whole Grain Activity Assembly

$\square$ Using a permanent marker, label enough ( 1 or 2 gallon) bags to hold the boxes/labels for the "Is It a Whole Grain?" activity with the label, "Is It a Whole Grain?" Then put the boxes/labels for this activity into the marked bag.

\section{Breakfast Choices Assembly}

$\square$ Using a permanent marker, label enough (1 or 2 gallon) bags to hold the boxes/labels for the "Breakfast Choices" team challenge with the label, "Breakfast Choices". Then put the boxes/ labels for this activity into the marked bag.

\section{Set Up Notes}

- Prior to the lesson, ask the classroom teacher if the classroom's computer and projector can be used. If not, allow time to set up equipment being brought in or use the KidQuest Flipchart.

- Prior to starting the lesson if possible, set up 4 stations around the room for the Grains \& Breakfast Challenge Activities. Tape one of the posters to a desk or table signifying that station and place the bagged contents for that station on the desk or table. Note: The Think Tank activity does not require any additional materials for that station. 


\section{LESSON 4: POWERPOINT/FLIPCHART NOTES}
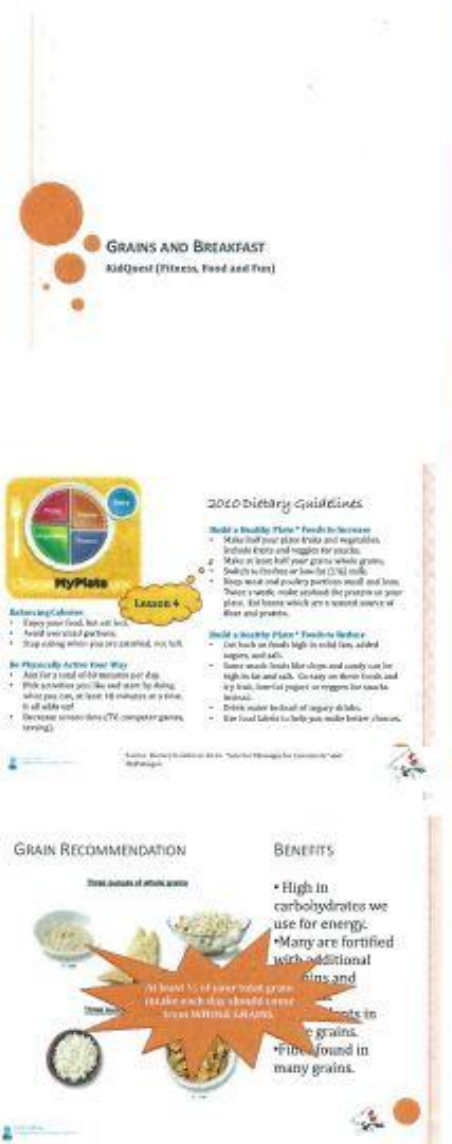

2

a

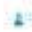

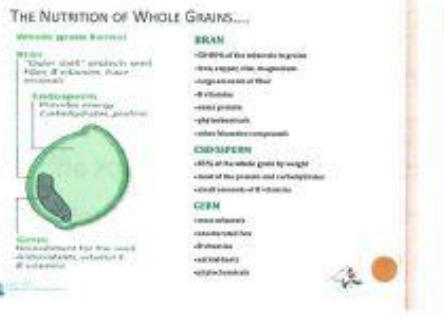

South Dakota

Cooperative Extension Service
Explain to the group that the topic today is, "Grains and Breakfast." In this activity we will be identifying the benefits of eating breakfast and whole grains. Then you will be teamed up into 4 different teams to take a Grains and Breakfast challenge.

Hand out the Screen Family Fun Packs. Encourage participants to take the Quest Challenges for this Screen pack and tell them the due date for completion. Remind participants that the Screen Pack is the last Family Fun Pack for the program. Ask participants if they have any questions about the Family Fun Packs.

The Dietary Guidelines give us tips to Build a Healthy Plate by increasing certain food groups like fruits and veggies, whole grains and lowfat dairy. Our lesson today focuses on ways to include more whole grains in your day and to eat breakfast. The key messages for this lesson will be to make at least half of your grains whole grains and to avoid skipping breakfast.

Explain to participants the daily recommendation for grains is around 6 servings. Explain that a serving size is: 1 slice of bread, $1 / 2$ cup of noodles, $1 / 2$ cup of oatmeal, $4-6$ crackers and $3 / 4$ to 1 cup of cereal. Then point out the following regarding grains: grains are high in carbohydrates which our body needs daily for energy and brain fuel. Many grain products like breakfast cereal are fortified with additional vitamins and minerals that our body uses to stay healthy. Tell participants that at least $1 / 2$ of their grain servings should come from whole grains because they usually have more vitamins, minerals and fiber than refined grains.

Using the Whole Grain slide, explain the 3 different parts of a whole grain and what is included in each. Point out that fiber is a very important type of carbohydrate helpful in regular digestion and disease prevention. Fiber also helps to fill us up so we don't eat as much other stuff that might not be as good for us. Source: Wheat Foods Council

\section{Newterters Notes:}

25 


\section{LESSON 4: POWERPOINT/FLIPCHART NOTES}

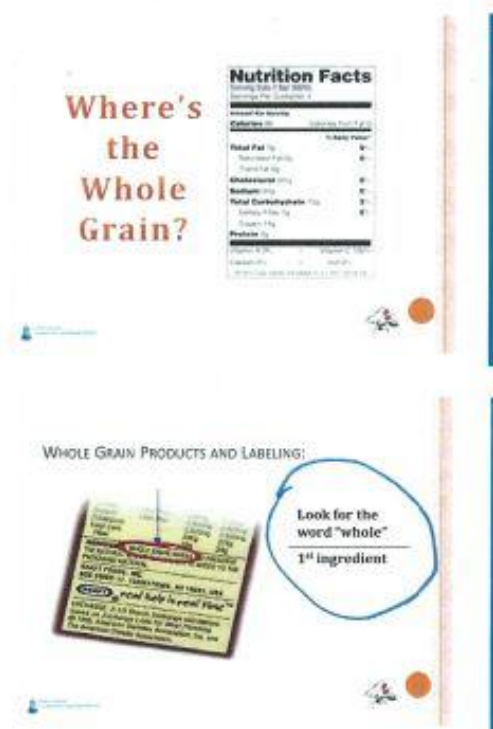

Using the Food Label slide, point out the area on the label indicating carbohydrates and explain that fiber and sugars are types of carbohydrates. Note that there isn't a \%DV (daily value) for sugar but we can compare and limit added sugars by looking at the amount of sugar grams. Encourage participants to pick items with fiber. Note that the main part of the food label doesn't tell us if it is a whole grain or not.

Using the Food Ingredient slide or poster, explain that this is the part of the label we can use to see if the food product is made with whole grains. Explain that the word whole must be present to indicate if it has whole grains or not. Except for food ingredients that are naturally whole grains like oats and popcorn. Also explain that the ingredient lists items in the order they are added and it is good to choose grains with whole grain listed as the 1 st or 2 nd ingredient.

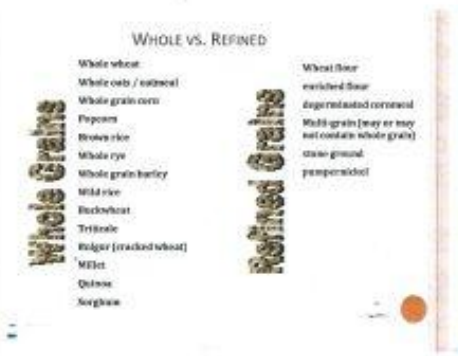

Using the Whole Grains vs. Refined Grains slide, point out what would be considered a whole or refined grain and how it is recommended to limit refined grains.

Wars TO ADO WHOLE GRN TO VOVI DIET......

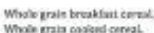

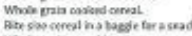

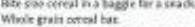

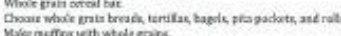
Peqpasnez

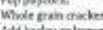

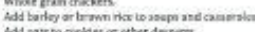

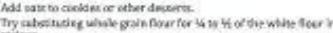

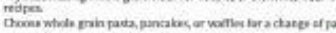

South Dakota

Ask participants how they could increase their intake of whole grains. Point out the following if not mentioned by participants: choose whole grain breakfast cereal and whole grain cooked cereal, pack a whole grain cereal in a baggie for a snack, choose cereal bars made with whole grains, choose whole grain breads, tortillas, bagels, pita pockets and rolls, make muffins with whole grains, pop popcorn, choose whole grain crackers, add barley or brown rice to soups and casseroles, add oats to cookies or other desserts, try substituting whole grain flour for $1 / 4$ to $1 / 2$ of the white flour in recipes, choose whole grain pasta, pancakes or waffles for a change of pace.

Leader's Notes: 


\section{LESSON 4: POWERPOINT/FLIPCHART NOTES}

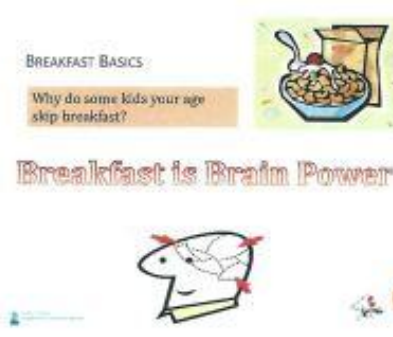

BENESTS OF BREAK.FAST

-More energy

- Less moody

- Less irritable

-Better grades

- L.ess complaints of not feeling well

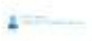

$x^{2}$

Befaksast Tirs

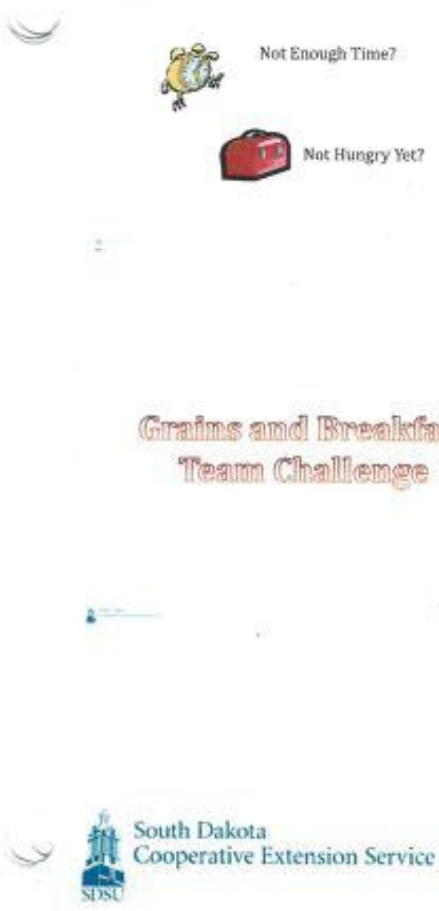

If not mentioned, point out the common excuses for skipping. breakfast: no time, not really hungry, trying to lose weight. Actually, skipping breakfast is not effective for trying to lose weight in studies. Our brain requires glucose to function so when it has gone without any glucose for a long time it doesn't function as well.

Go thru points on the slide.

Ask participants for their ideas on what kids their age could do to make sure they eat breakfast. Allow a little time for answers. If not mentioned by participants, provide the following suggestions: Not enough time- go for quick to fix or grab and go like lowfat whole grain granola bars and a piece of fruit, quick meat and cheese sandwich, yogurt, eat breakfast at school or get up 10 minutes earlier. Not really hungry yet- pack something quick to eat for later in the morning.

Introduce the Grains and Breakfast Team Challenge activity. Number participants from 1 to 4 .

Direct participants to find the other members of their team. Then provide each team with one of the sets of challenge activities sheets.

Instruct each team to start at the station which is the first page of their challenge activities papers.

Allow the groups 3-5 minutes at each station.

After each group has had an opportunity to visit each station, instruct the participants to return to their seats.

Go thru the answers for each of the challenge sheets and ask participants if they have additional questions.

\section{Header's Notes:}




\section{LESSON 4: POWERPOINT/FLIPCHART NOTES}

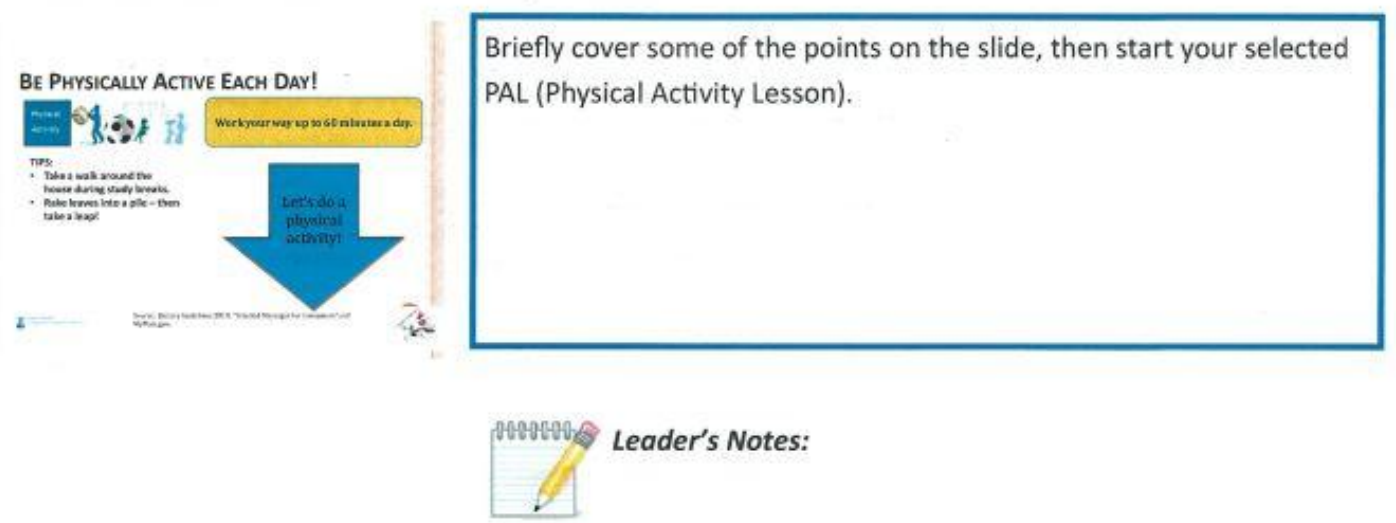

$$
\text { South Dakota }
$$




\section{Lesson 5: Dairy}

\section{LESSON 5: DAIRY}

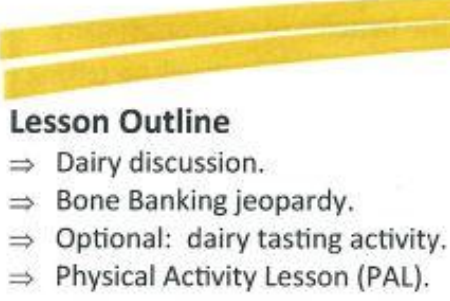

Materials and Preparation

$\square$ Computer, projector, KidQuest $C D$ with lesson five powerpoint and Bone Banking Jeopardy or the KidQuest flipchart and a prepared jeopardy board as described below.

$\square$ Select the PAL and gather any materials required for the selected PAL. (See PAL Section)

$1(12 \mathrm{oz})$ size plastic milk container ( $1 \%$ or skim).

1 (8 oz or smaller) lowfat yogurt container.

If available, dairy food models to represent the different serving sizes of dairy foods.

Optional: enough $2 \%$ reduced fat cheese sticks or lowfat yogurt for everyone to taste.

If computer/projector not available: -1 copy each of the Bone Banking jeopardy activity sheets. (See Activity Supplements Section). Cut the sheets in $1 / 2$. If printing from the KidQuest CD, print front to back, two sided. - 1 display board (at least $36^{\prime \prime} \times 48^{\prime \prime}$ ) -velcro sticky fasteners

South Dakot

Cooperative Extension Service

\section{ACTIVITY OUTCOMES}

- Participants will be able to name the recommended daily servings of dairy foods and how dairy foods play a role in providing adequate calcium.

- Participants will identify and select dairy foods that meet their recommended daily intake of nutrients.

\section{Set Up}

- Wash and rinse the milk and yogurt containers.

- If tasting any food with this lesson, ask the classroom teacher in advance if there are any children with food allergies.

- Prior to the lesson, ask the classroom teacher if the classroom's computer and projector can be used. If not, allow time to set up equipment being brought in or use the KidQuest Flipchart.

- If a computer/projector is not available: prepare the jeopardy game by arranging the Bone Banking jeopardy activity sheets on the display board and attaching the points/question cards with velcro so they can be easily removed to reveal the answer to questions. 


\section{LESSON 5: POWERPOINT/FLIPCHART NOTES}
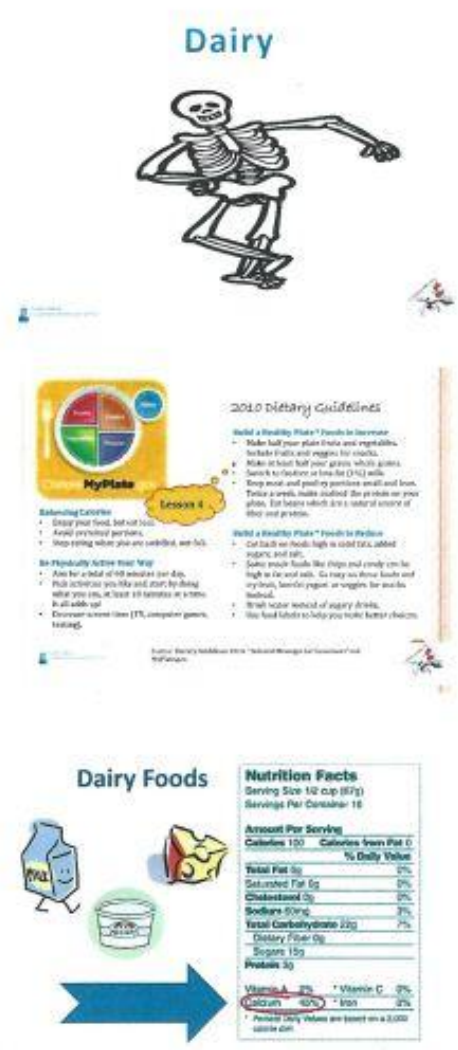

Percentage of children achieving the recommended daily adequate intake for calcium.

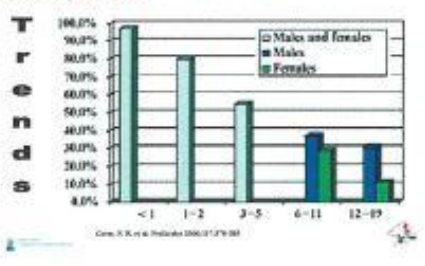

Explain to the group that the topic today is, "Dairy."

In this activity we will be identifying the benefits of consuming dairy

which provides us with many nutrients. In particular we will be talking about calcium and how important it is to get enough calcium in your diet at your age to protect your bones later. Then you will be teamed up into 4 different teams to play a Bone Banking jeopardy game.

The Dietary Guidelines give us tips to Build a Healthy Plate by increasing certain food groups like fruits and veggies, whole grains and lowfat dairy. Our lesson today focuses on ways to include more lowfat dairy into your day.

Milk, yogurt and cheese are naturally excellent sources of calcium, Go for lower fat versions when choosing these foods. To check the calcium content of other foods, check the label. The \% DV (daily value) for calcium is listed. This is based on the amount needed for most adults which is only $1000 \mathrm{mg}$ per day and you need around $1300 \mathrm{mg}$ per day. If a product has around $20 \%$ DV for calcium, it is considered a high source of calcium.

This slide shows that as children turn into teens, they decrease their intake of milk.

Leader's Notes: 


\section{LESSON 5: POWERPOINT/FLIPCHART NOTES}

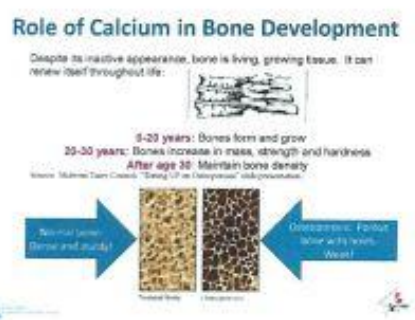

Role of Calcium in Bone Development

Peak calcium accumulation fate is at abe 12.5 yrs foc giris and 14 yrs for boys.

40s of total ilferime bone trass is accumulated

during this time.?

By age 20 , the average Woure persen has acquire

about $98 \%$ of their steletel mass.
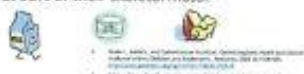

Consequences of Inadequate Calcium Intake

- Possible increase in fractures.

- Biggest concern $\Longrightarrow$ Osteoporosis.

- Osteoporosis means porous bone

- Porous bone is not as strong.
To understand osteoporosis, you need to know about bones. Bone is living, growing tissue. It changes and renews itself throughout life. Old bone is removed and new bone is laid down. Bone formation is critical from birth to 20 years of age. $45 \%$ of the body's total skeletal mass is formed during the adolescent growth spurt alone. Building strong bones during childhood and adolescence can be the best defense against developing osteoporosis later.

By age 20, you have probably reached your full adult height. But until age 30 , your bones are still increasing in mass, strength and hardness. The key to having strong, dense bones is to replace what is lost. Think of it like this: bone is like your bank account: you want to make sure your "withdrawals" don't exceed your "deposits" or you may wind up overdrawn-and at greater risk of osteoporosis.

Read point on the slide. So you really just have this one chance to protect your bones for later in life.

Read points on the slide.

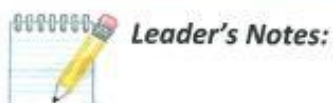




\section{LESSON 5: POWERPOINT/FLIPCHART NOTES}

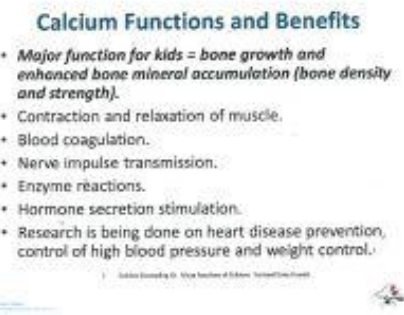

Calcium Requirements

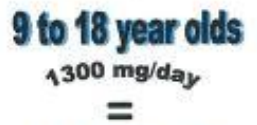

4 Servings/Day
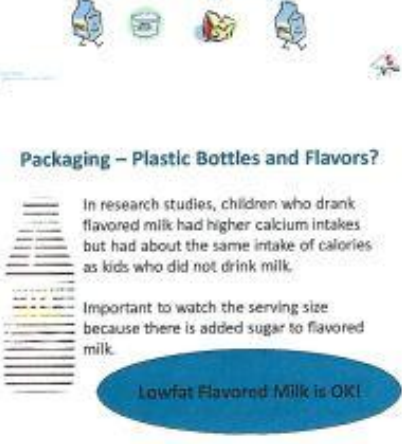

Weight Bearing Exercise is Important Too.

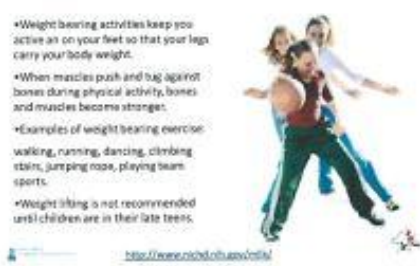

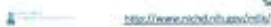

South Dakota

Cooperative Extension Service
Summarize points on the slide.

One cup of milk has about $320 \mathrm{mg}$ of calcium. One cup of yogurt has about 300 to $400 \mathrm{mg}$ of calcium and $1 \mathrm{oz}$. of cheese has around 180 $200 \mathrm{mg}$ of calcium.

Ask participants, how many servings do you have each day?

Go thru points on the slide.

Sources: Roper ASW (2002). School Milk Pilot Study: Sales Test, September 2001June 2002, Dairy Management Inc. and American School Food Service Association, Unpublished.

Johnson, R, Frary C, Wang M. The Nutritional Consequences of Flavored Milk Consumption by School Aged Children and Adolescents in the United States. Journol of the American Dietetic Association. June 2002:102;6. pages 853855.

Summarize points on the slide.

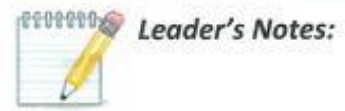




\section{LESSON 5: POWERPOINT/FLIPCHART NOTES}

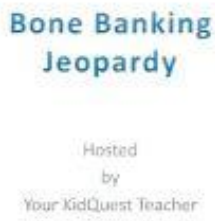

Next, explain to the group they will be divided into groups to play a game called Bone Banking Jeopardy. Each team will take a turn selecting a category and dollar amount question. Minimize the current

6 Lesson 5 powerpoint and open the Bone Banking Jeopardy game.

If your team correctly answers the question, they will receive the number of dollar points listed on the question. If your team incorrectly answers the question, they will have the number of dollar points listed on the question deducted from their total. Your team can choose to pass on the question which will then go to the next team's turn. If that team chooses to pass on the question, then the team who originally passed on the question will need to attempt to answer the question. If the team who got passed the question decides to answer the question, they will also get the chance to answer another question of their choosing. The chances column is a gamble. In this column you won't be provided with any questions to answer but rather you will either receive points or points will be taken away. The game continues until all of the question categories have been selected or as time allows making sure to provide each team the same number of turns.

Once the game is over, ask the participants if they learned anything new about calcium and strong bones. Review some quick and easy ways to include dairy in the diet: $1 \%$ or skim milk with all of your meals, lowfat yogurt for a tasty treat or a cheese sandwich for a quick to fix breakfast or healthy snack. If tasting food, have participants wash their hands then distribute the snack.

\section{Leader's Notes:}


Lesson 6: Media Connections

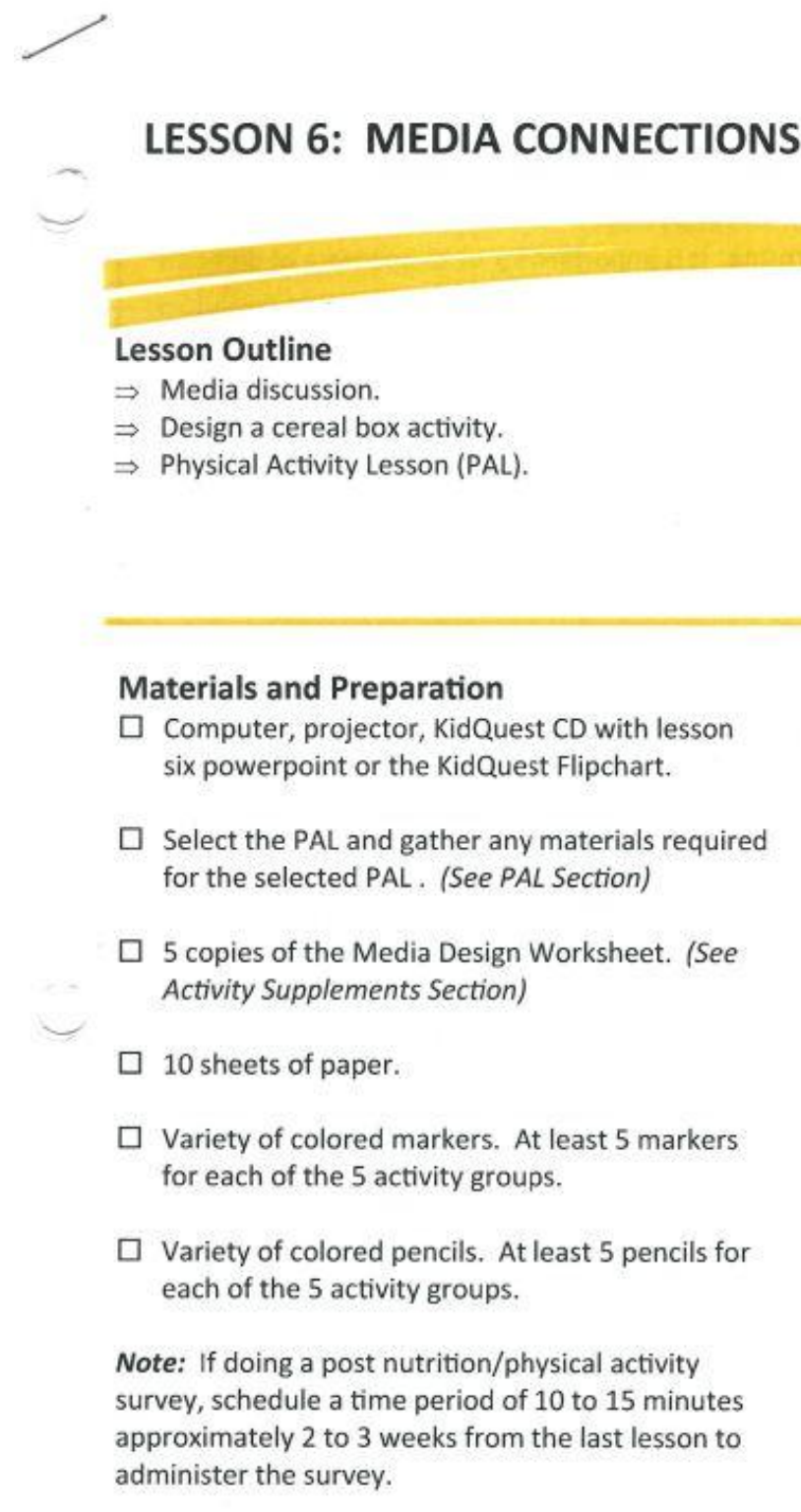

\section{ACTIVITY OUTCOMES}

- Participants will learn about advertising of food products.

- Participants are presented with the tools needed to determine fact from fiction when making food buying decisions.

\section{Set Up}

- Prior to the lesson, ask the classroom teacher if the classroom's computer and projector can be used. If not, allow time to set up equipment being brought in or use the KidQuest Flipchart. 


\section{LESSON 6: POWERPOINT/FLIPCHART NOTES}

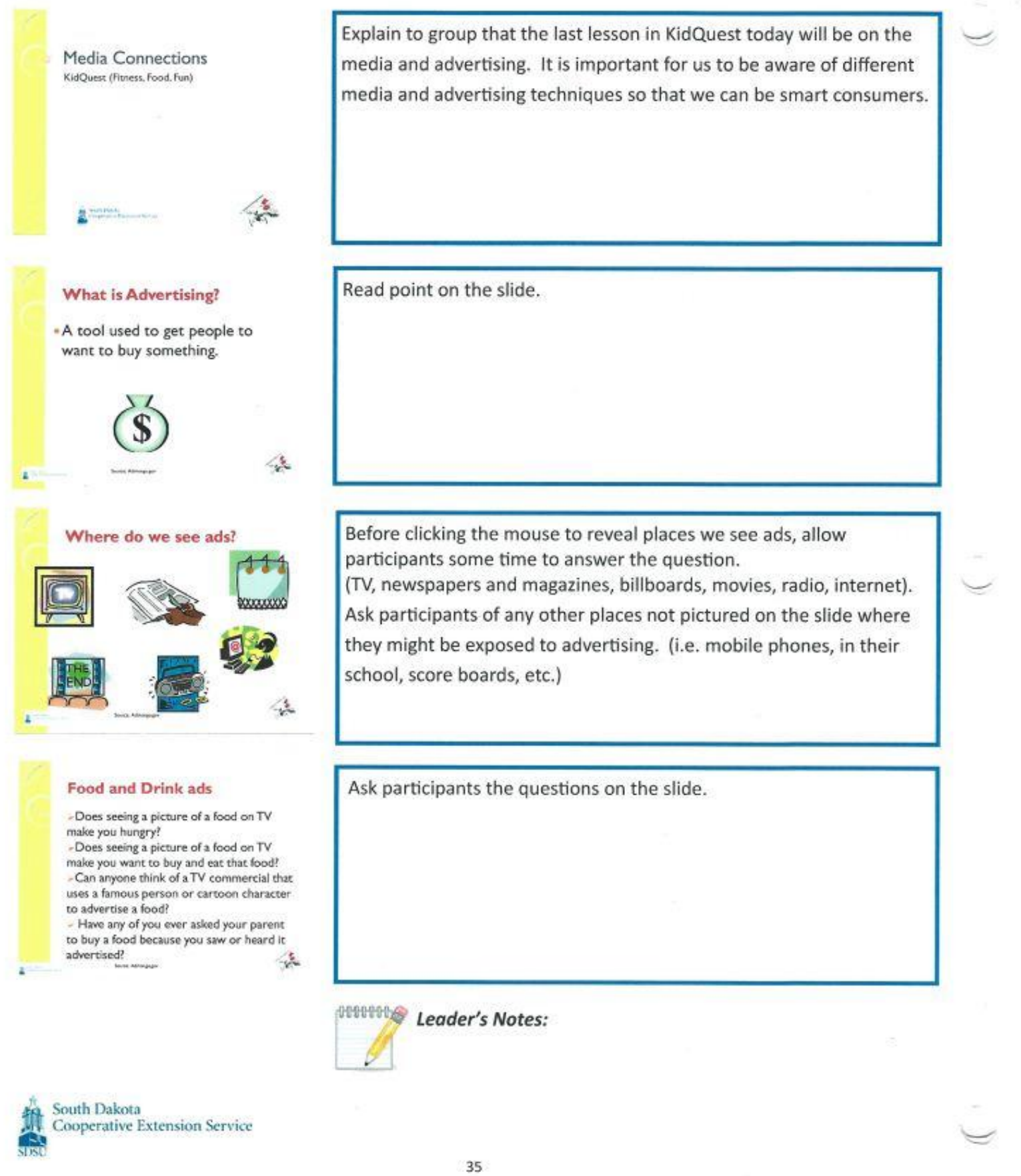




\section{LESSON 6: POWERPOINT/FLIPCHART NOTES}

\section{Advertisers}

- Glve people info to help them decide wha: to buy.

Advertisers talk about special feacures of their products to corvinice people to buy them.

Ads helps pay for the cost of programs on Adevision, on radio and online.

Adverrisers are required by law to tell the there are some who strerch the oruth

Advertisers want you to think of their point

of view.

2

Do you Agree with the Point of view?

- - You can't be a real athlete without drink?"

\section{Consumers}

- Someone who buys and uses products and

services

Smart consumers are aware of

Who is responsible for the ad?

What is the ad actually saying?

What does the ad want you to buyidolor
think?

What do other people think?

Does it fit into their budget?

6. Where else can they find reliable info?

i clsecan the

\&

Ad Targeting Techniques

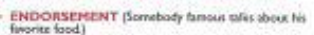

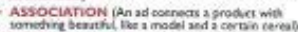

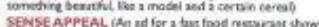
SENSEAPPEML fir malor a

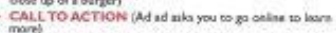

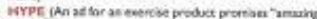
CAMim approsos li

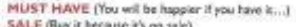
nom

s

st
Read points on the slide.

Allow some participant discussion. Point out that many tads try to get you to think a certain way so it's important to take a step back and think about what they are trying to say. We will go thru some tips for doing just that.

You can be a smart consumer by asking yourself some important questions. Read points on the slide.

Summarize the ad targeting techniques.

\section{Leader's Notes:}




\section{LESSON 6: POWERPOINT/FLIPCHART NOTES}

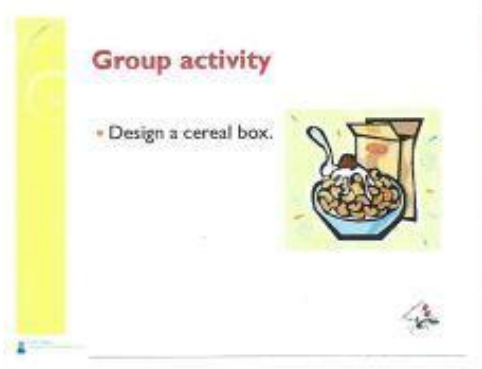

To finish our lesson on the media, you will be put into 5 different groups.

Each group will be given a Media Design Worksheet that will help your group to design a cereal box that appeals to other kids in your age group. Your group will be given some paper and other materials they may use to complete their design.

Your group will have around 15 minutes to complete the activity. When time is up - each group will present their cereal box.

Optional: if time allows, ask the group to put their heads on their desks. Then have them vote for the cereal they would most likely buy by raising their hand as you say, box 1 , box 2 , etc.

As time allows, do one of the physical activity lessons.

Thanks for letting us come into your classroom. Have a great rest of the school year!

\section{THANKVOO}




\section{Appendix 0}

KidQuest Family Fun Packs (4 Packs) 
Family Fun Pack 1: Snack Pack

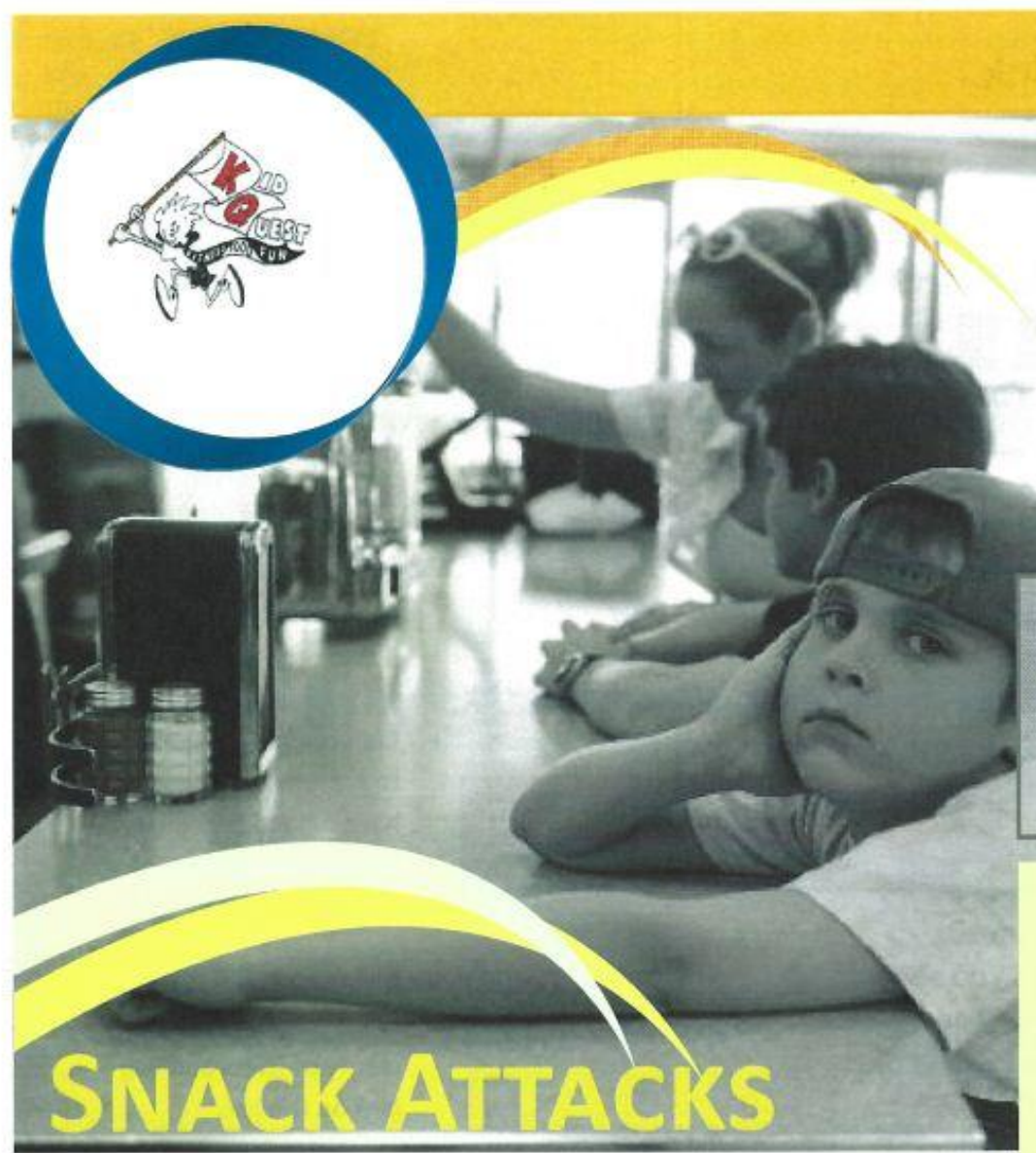

Kids are on the go and growing fast. Healthy snacks can provide what they need to satisfy hunger and fill any nutrient gaps missed at meals. However. consistent snacking without paying attention to how much or what is eaten can lead to an over abundance of calories and fat.

"More Of" Snack Ideas:
Fruit Veggies Dried Fruit
Jerky Toast Pretzels
Cereal Popcorn Crackers
Lowfat Milk and Cheese
Meat Sandwich Veggie Soup
Oatmeal Packets
Veggies with Lowfat Dressing or Dip
Lowfat Granola or
High Fiber Breakfast Bars

"More Of" and "Less Of" SNACKS Make it harder for everyone to overeat on high fat and calorie snacks by making them less available at home. Check out the nutrition label and choose snacks with less than 200 calories and less than $10 \%$ daily value total fat per serving. (Remember that most snack packages contain several servings per package.) Try making your own 100 calorie snack packs by portioning out smaller servings into individual baggies.

\section{Snack Pack}

KidQuest Family Fun Packs
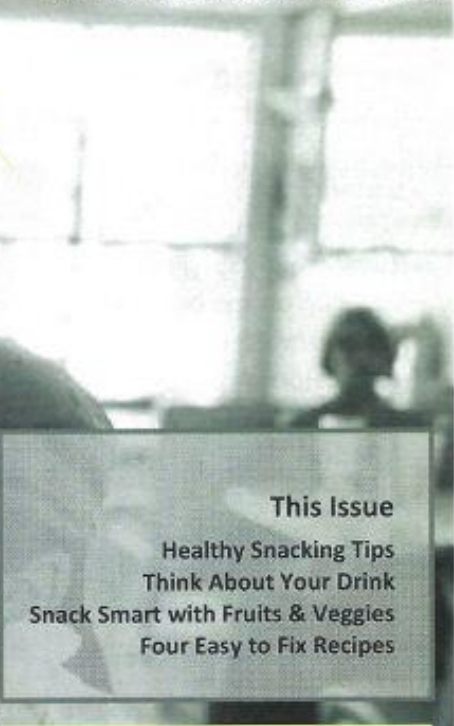

\section{Quest Challenges}

The KidQuest program recognizes the very important role family members play in the health of their children. Each of the KidQuest Family Fun Packs contain Quest Challenges. We encourage you to work with your child to complete as many of the Quest Challenges as possible. Children who return a Quest Challenge sheet with their parent's signature will be eligible to redeem a prize (only in participating classrooms)!

\section{FeEdBack WANTEd!}

Please let us know what you think by completing the enclosed Feedback information and returning it along with the Quest Challenge information to your KidQuest Youth's classroom. Thank You!

\section{Limit "Less Of" Snacks}

$\begin{array}{llll}\text { Chips } & \text { Pop } & \text { Candy Ice cream } \\ \text { Cookies } & \text { Cake } & \text { Sugar Sweetened Drinks, Juice and Sports drinks }\end{array}$

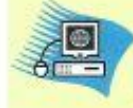

Find Out More At: www.mealsmatter.org www.smallstep.gov 


\section{Think About the Drink}

Instead of regular pop and other sugary drinks like sports drinks and juice, try:

- water

- skim or $1 \%$ milk

- $100 \%$ fruit juice (limit to 1 cup or less per day)

- flavored water with zero calories

- caffeine free and sugar free tea

- diet drinks

- fitness water with 20

calories or less per serving.

\section{SNACK SMART WITH FRUITS AND VECGIES}

\section{DID YOU KNOW?}

A 20 oz bottle of soda has 275 calories and 78 grams of sugar.

\section{That's like 20 teaspoons of sugar!}

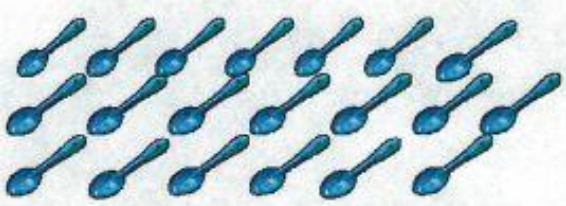

Note: If Sports drinks are desired, then look for the lower calorie options.

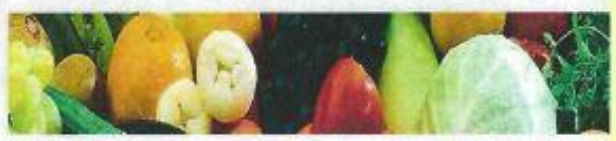

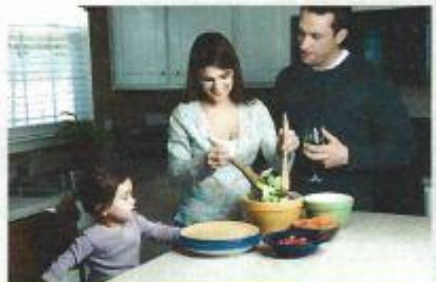

Healthy Family Habits

- Instead of rewarding kids with food, try rewarding with extra attention, praise or other non-food rewards.

- Children are more likely to try new foods if they have a hand in selecting and preparing them.

- Make a grocery list before you shop including plenty of fruits and veggies on the list.

Fruit \& Veggie Snack Advantages:

- low in calories

- low in fat

- high in vitamins, minerals \& fiber

- taste great

- can help reduce risk of some cancers

- can help control weight
- Choose a checkout line without a candy or chip display.

- Park farther from your destination and walk. and pack one for yourself.

Store cleaned, cut up veggies in the fridge at eye level and keep a low fat or fat free dip on hand.

- Encourage your child to choose his or her own fruits and veggies when grocery shopping.

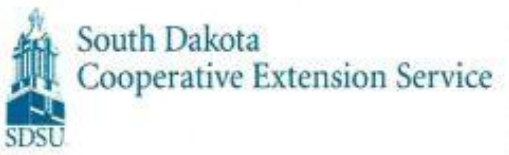

Developed by: Becky Jensen, MS, RD, LN, South Dakota State University. July 2011. These materials may be reproduced for educational purposes only. Contact: becky.jensen@sdstate.edu

Educational programs and materials offered without rogard for race, color, creed, religion, national origin, ancestry, citizenship, age, gender, sexual orientation, disability, or Vietnam Era Veteran status. South Dakota State University, US. Department of Agriculture and courty cooperating. An Equal Opportunity Employer. 


\section{Snack Pack Recipe Cards}

\section{Banana Yogurt Shake}

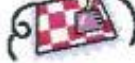

Ingredients

ㅁ $1-1 / 2$ cup fat free or $1 \%$ milk

ㅁ 4 small or 3 medium sized bananas, peeled

ㅁ 1 cup lowfat vanilla or strawberry yogurt

1 tsp vanilla

ㅁ $1 / 2$ tsp cinnamon

- $1 / 8$ tsp nutmeg (optional)

$\square 1$ cup of ice cubes

Recipe from Becky Jensen, MS, RD, LN (SDSU Extension
Estimated Time: 10 minutes

Serving Size: 4 to 6 oz

Makes: 4 servings

Instructions

Combine all ingredients except ice cubes in a blender or food processor. Process until thick and creamy. With motor running, add ice cubes and process until smooth. Pour into tall glasses to serve.

Nutrition Facts Per Serving:

Calories 130 Total fat $1 \mathrm{~g}$ Sat Fat $0.5 \mathrm{~g}$ Chol $5 \mathrm{mg}$

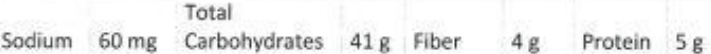

Recipe from the Dole 5 A Day Kids Snack Recipe Contest.

\section{Apple Sandwich}

Ingredients

ㄴ 1 large apple

ㅁ 2 tablespoons raisins

$\square \quad 2$ teaspoons peanut butter

ㄴ 1 teaspoon cinnamon

\section{Estimated Time: 5 minutes}

Serving Size: 2 sandwiches

Makes: 2 sandwiches

\section{Instructions}

Core the apple and slice into at least eight slices, about 1/4 inch thick. Spread a thin layer of peanut butter on one side of an apple slice. Sprinkle with a few raisins, then top with another apple slice. Sprinkle the top of the sandwich with a little cinnamon sugar. Continue assembling your sandwiches until all the apple slices have been used.

\section{Nutrition Facts Per Serving:}

\begin{tabular}{|c|c|c|c|c|c|c|c|}
\hline Calories & 125 & Total Fat & $3 g$ & Sat fat & $0.5 \mathrm{~g}$ & Chol & $0 \mathrm{mg}$ \\
\hline Sodium & $30 \mathrm{mg}$ & $\begin{array}{l}\text { Total } \\
\text { Carbohydrates }\end{array}$ & $25 \mathrm{~g}$ & Fiber & $3 g$ & Protein & $2 g$ \\
\hline
\end{tabular}

South Dakota

Cooperative Extension Service
Developed by: Becky Jensen, MS, RD, LN, South Dakota State University. July 2011. These materials may be reproduced for educational purposes only.

Educational programs and materials offered without regard for race, color, creed, religion, national origin ancestry, citizenship, age, gender, sexual orientation, disability, or Vietnam Era Veteran status. South Dakota State University, U.S. Department of Agriculture and county cooperating. An Equal Opportunity Employer. 


\section{Snack Pack Recipe Cards}

\section{Simple Snack Mix}

\section{Ingredients}

ㅁ 1 cup of whole grain cereal (squares or O's work best)

ㅁ 1/4 cup of dried fruit (your choice)

1/4 cup of nuts such as walnut pieces, slivered almonds or pistachios

ㅁ 1/4 cup of lowfat whole grain snack crackers or pretzels

\section{Nutrition Facts Per Serving:}

$\begin{array}{lllllllll}\text { Calories } & 240 & \text { Total Fat } & 7 \mathrm{~g} & \text { Sat Fat } & 0.5 \mathrm{~g} & \text { Chol } & 0 \mathrm{mg} \\ & & \text { Total } & & & & & \\ \text { Sodium } & 390 \mathrm{mg} & \text { Carbohydrates } & 41 \mathrm{~g} & \text { Fiber } & 4 \mathrm{~g} & \text { Protein } & 6 \mathrm{~g}\end{array}$

\section{Instructions}

Combine all ingredients into a large bowl and stir. Measure out $1 / 2$ cup servings into a bowl, cup or baggie for individual snacks.

Estimated Time: 5-10 minutes

Serving Size: $1 / 2$ cup

Makes: $3-4$ servings

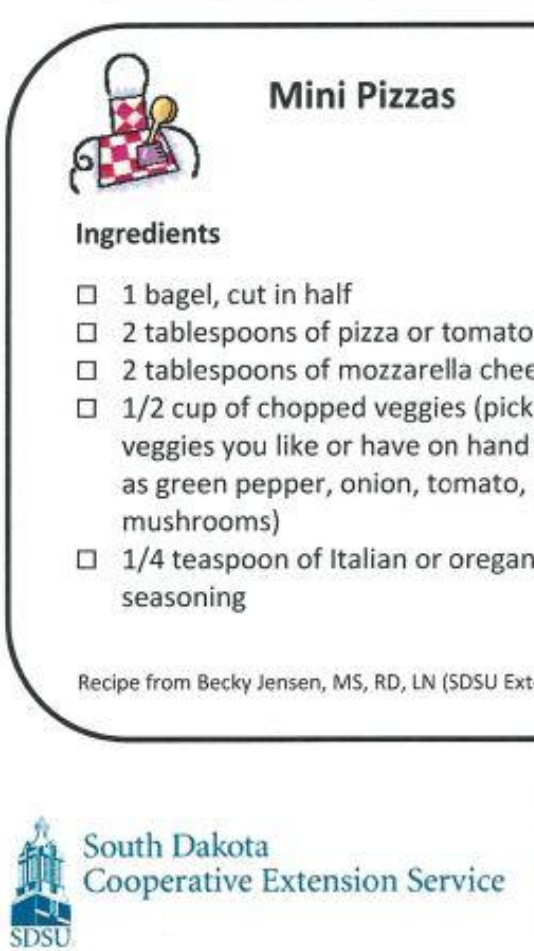

Estimated Time: 10 minutes

Serving Size: 2 mini pizzas

Makes: 1 serving

\section{Instructions}

Preheat oven to 325 degrees Fahrenheit. (Make sure an adult assists you or has provided permission for you to use the oven). Place bagel on an oven safe pan. Spread tomato sauce on each bagel half. Then top with the chopped veggies and cheese. Bake in the oven for about 5 to 8 minutes. Let cool for 2 minutes and then enjoy your mini pizzas.

\section{Nutrition Facts Per Serving:}

$\begin{array}{lllllllll}\text { Calories } & 340 & \text { Total Fat } & 6 \mathrm{~g} & \text { Sat Fat } & 3 \mathrm{~g} & \text { Chol } & 10 \mathrm{mg} \\ \text { Sodium } & 770 \mathrm{mg} & \begin{array}{l}\text { Total } \\ \text { Carbohydrates }\end{array} & 58 \mathrm{~g} & \text { Fiber } & 5 \mathrm{~g} & \text { Protein } & 15 \mathrm{~g}\end{array}$

Developed by: Becky Jensen, MS, RD, LN, South Dakota State University. July 2011. These materials may be reproduced for educational purposes only.

Educational programs and materials offered without regard for race, color, creed, religion, national origin, ancestry, citizenship, age, gender, sexual orientation, disability, or Vietnam Era Veteran status. South Dakota State University, U.S. Department of Agriculture and county cooperatinz. An Equal Opportunity Employer. 


\section{Snack Pack Quest Challenge}

\section{Qwest Challenges to Trys}

Put a check in the box when the following challenges are completed.

$\square$ I snacked on fruit or veggies for at least 5 different snack times.

Put a slash thru the number below to help you keep track of when you have reached 5 times

$$
123345
$$

$\square$ One or more members of my family tried one or more of the recipes in this snack pack.

$\square$ I went through our kitchen and made a list of snacks we have to eat more of and those to eat less of (use the back of this sheet to write some of those down).

$\square$ I talked with my parents about healthy snacks we should have at our house.

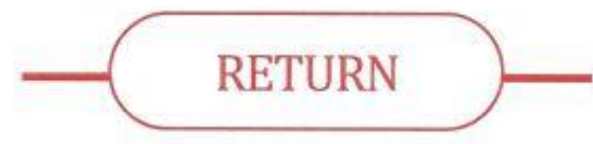

Bring this sheet back to the classroom.

Keep the information, tips and recipe sheets.
- Complete as many of the tasks as you can.

- Sign your name on the bottom of the card.

- Have your parent sign their name on the bottom of the card.

- Bring this sheet back to your classroom.

- Pick a prize from the prize box with your teacher's permission.

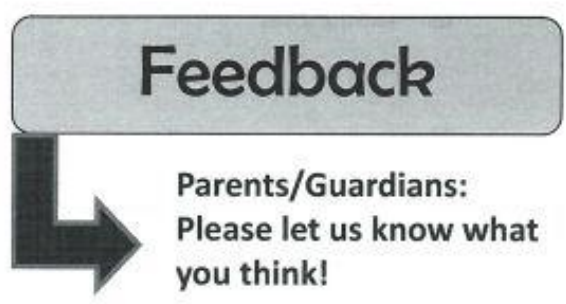

Please take a short survey found on the back of this page.

Youth Signature:

Date:

Parent Signature:

Date:

Developed by: Becky Jensen, MS, RD, LN, South Dakota State University. July 2011. These materials

South Dakota may be reproduced for educational purposes only.

Cooperative Extension Service

Educational programs and materials offered without regard for race, color, creed, religion, national origin, ancestry, citizenship, age, gender, sexual orientation, disability, or Vietnam Era Veteran status. South Dakota State University, U.S. Department of Agriculture and county cooperating. An Equal Opportunity Employer. 


\section{Feedback}

1. Overall, how would you rate your family's selection and intake of healthy snacks for the situations in a and b below?:

(circle one rating on a scale of 1 to 5 with $1=$ not so healthy and $5=$ very healthy)
a. Before Using the Snack Pack
12

23

4
b. After Using the Snack Pack

1

23

$\begin{array}{ll}4 & 5 \\ 4 & 5\end{array}$

2. The information in the Snack Pack provided us with tips we have used or plan to use: (please check only one answer)

YES

$\square$ NO UNSURE

3. Please put a check mark by the recipes in the Snack Pack that were tried by at least one member of your family:

$\square$ banana yogurt shake simple snack mix

$\square$ mini pizzas

apple sandwich

4. Please rate the overall usefulness of the Snack Pack in helping your family to achieve and maintain healthy eating habits:
Somewhat useful
Very useful
Not very useful

5. Please comment and or provide suggestions for ways we could improve the Snack Pack in the space below. 


\section{Family Fun Pack 2: Meal Pack}

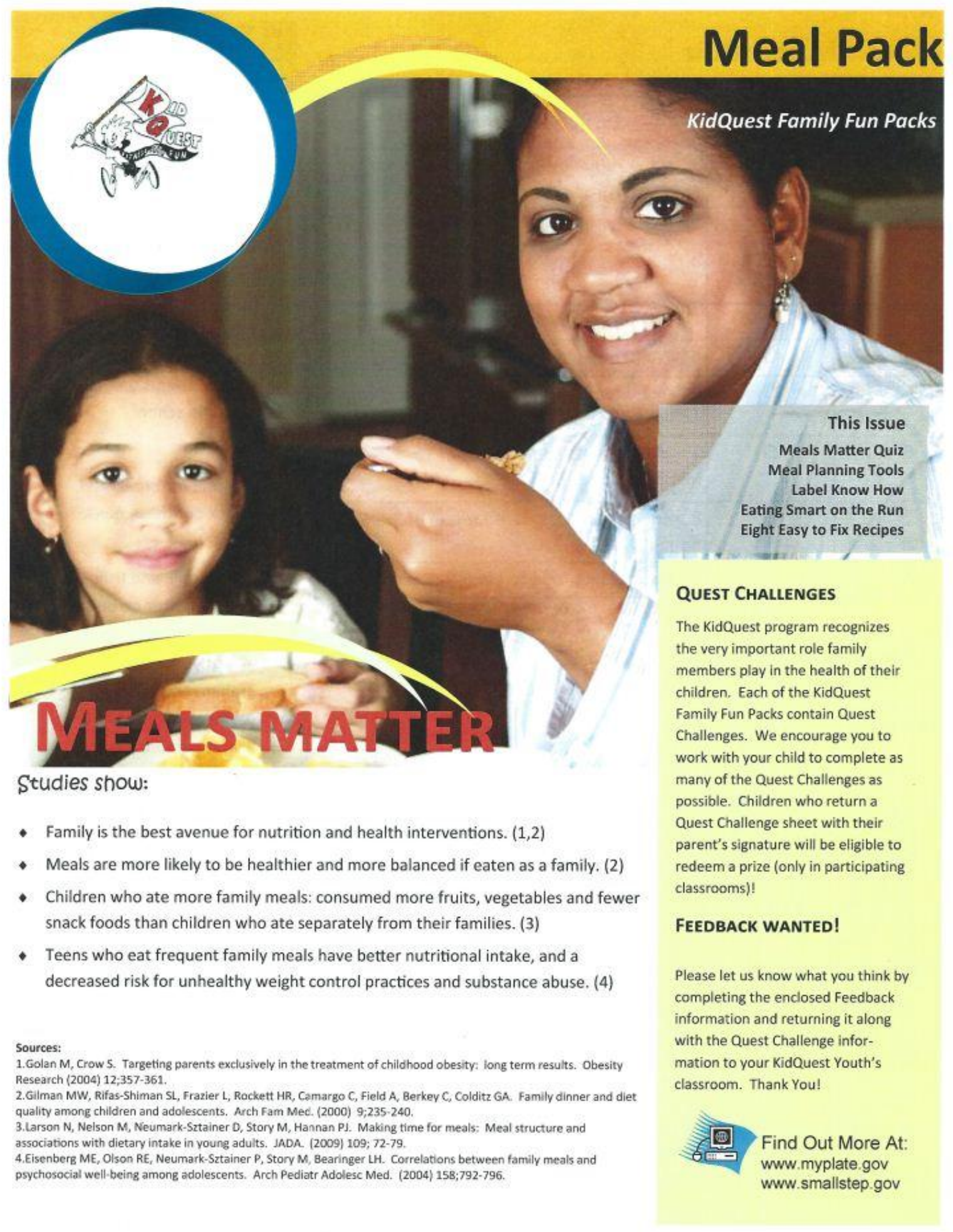


Meals Matter Quiz

\begin{tabular}{|c|c|c|c|}
\hline YES & NO & Sometimes & Do you and your family: \\
\hline 0 & 0 & 0 & $\begin{array}{l}\text { 1. Have regularly scheduled mealtimes } \\
\text { when you are home? }\end{array}$ \\
\hline 0 & 0 & 0 & 2. Eat meals together at least once a day? \\
\hline O & 0 & O & $\begin{array}{l}\text { 3. Plan and prepare meals together once a } \\
\text { day? }\end{array}$ \\
\hline 0 & 0 & 0 & 4. Eat three meals every day? \\
\hline 0 & 0 & O & 5. Try to make mealtimes pleasant? \\
\hline 0 & 0 & 0 & $\begin{array}{l}\text { 6. Avoid making everyone eat everything } \\
\text { on their plate before leaving the table? }\end{array}$ \\
\hline O & 0 & 0 & $\begin{array}{l}\text { 7. Make meals last more than } 15 \\
\text { minutes? }\end{array}$ \\
\hline 0 & 0 & 0 & $\begin{array}{l}\text { 8. Eat only in designated areas of the } \\
\text { house? }\end{array}$ \\
\hline 0 & 0 & 0 & 9. Avoid using food to punish or reward? \\
\hline
\end{tabular}

Scoring the quiz:

- 2 points for every yes answer. - 1 point for every sometimes answer.

- 0 points for every no answer.

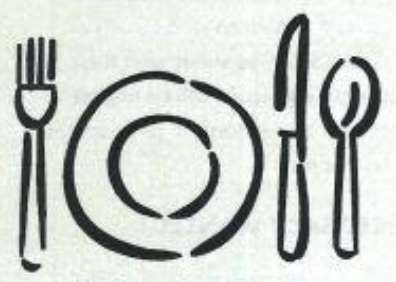

Meal Planning Tools

\section{4 to 18 points:}

Your family is doing a great job in these areas!

\section{7 to 13 points:}

This is good but it's time to work on moving sometimes answers to yes answers.

Less than 7 points: Check out more tips for healthy changes!

This survey was adapted from the Family Lifestyle Survey, pg 13 in, "If Your Child Is Overweight, a Guide for Parents". The American Dietetic Association. 3rd Edition, 2006.

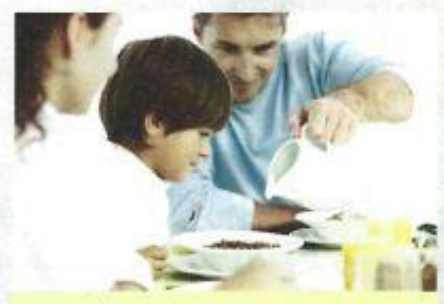

Healthy Family Habits

- Kids who eat breakfast are more alert, get more daily nutrients and do better in school.

- No time for breakfast? Check out these quick fixes:

$\Rightarrow$ cereal, milk and fruit

$\Rightarrow$ peanut butter on bread, bagels or English muffin

$\Rightarrow$ lowfat yogurt with graham crackers

$\Rightarrow$ oatmeal packet with fruit

$\Rightarrow$ lowfat granola bar and milk

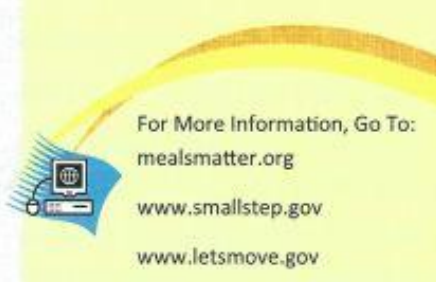

Start with a plan: Use recipes and cookbooks to develop a plan of meals for the week. Keep it simple and utilize recipes with fewer ingredients and steps. Also check out food you already have on hand. After you have planned out the family meals for the week, think about items you can prep in advance like thawing meat in the refrigerator or cutting up veggies to put in dishes.

Develop a Shopping List: Using your weekly meal plan, develop a shopping list. A shopping list can be a healthy time saving tool keeping you accountable to your shopping budget. Arrange your shopping list in categories as they would appear in the store aisles to save time. When developing your shopping list, take an inventory of what you already have on hand. 


\begin{tabular}{l} 
Labels Can H. \\
Family...... \\
Serving Sizes: \\
The nutrition \\
information \\
is based on \\
the serving \\
size. Many \\
packages \\
hold more \\
than 1 \\
serving. \\
\\
Get More \\
Fiber-look \\
for foods \\
with 3 \\
grams of \\
fiber or \\
more per \\
serving. \\
\hline
\end{tabular}

Nutrition Facts

Serving Size 2 tortillas $(51 \mathrm{~g})$ Servings Per Container 6

Amount Per Serving

Calories 110 Calories from Fat 10

\begin{tabular}{lr}
\hline & \% Dally Value \\
\hline Total Fat $1 \mathrm{~g}$ & $\mathbf{2 \%}$ \\
\hline Saturated Fat Og & $\mathbf{0 \%}$ \\
\hline Trans Fat Og & \\
\hline Cholesterol Omg & $\mathbf{0 \%}$ \\
\hline Sodium 30mg & $\mathbf{1 \%}$ \\
\hline Total Carbohydrate 22g & $\mathbf{7 \%}$ \\
\hline Dietary Fiber $2 \mathrm{~g}$ & $\mathbf{9 \%}$ \\
\hline
\end{tabular}

$$
\text { Sugars Og }
$$

Protein $2 \mathrm{~g}$

\begin{tabular}{|c|c|c|c|c|}
\hline \multicolumn{2}{|c|}{ Vitamin A O\% } & - & \multicolumn{2}{|c|}{ Vitamin C O\% } \\
\hline \multicolumn{2}{|l|}{ Calcium $2 \%$} & - & \multicolumn{2}{|c|}{ Iron $4 \%$} \\
\hline \multirow{2}{*}{\multicolumn{5}{|c|}{$\begin{array}{l}\text { - Percent Daily Values are based on a } 2,000 \\
\text { calorie diet Your daily values may be higner } \\
\text { or lower depending on your calorie needs: }\end{array}$}} \\
\hline & & & & \\
\hline Total Fat & Les & than & $65 \mathrm{~g}$ & $80 \mathrm{~g}$ \\
\hline Saturated Fat & Les & than & $20 \mathrm{~g}$ & $25 \mathrm{~g}$ \\
\hline $\begin{array}{l}\text { Cholesterol } \\
\text { Sodium }\end{array}$ & Les & than & $300 \mathrm{mg}$ & $300 \mathrm{mg}$ \\
\hline \multirow{2}{*}{\multicolumn{3}{|c|}{$\begin{array}{l}\text { Total Carbohydrate } \\
\text { Dietary Fiber }\end{array}$}} & $2.400 \mathrm{mg}$ & $2,400 \mathrm{n}$ \\
\hline & & & $\begin{array}{l}3009 \\
259\end{array}$ & $\begin{array}{l}375 \mathrm{~g} \\
30 \mathrm{~g}\end{array}$ \\
\hline
\end{tabular}

Check out the \% Daily Value (DV): This helps us determine if a food is high or low in a nutrient.

$5 \%$ DV or less is LOW

$20 \%$ DV or more is HIGH

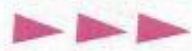

Choose foods with a high \%DV of Vitamin A, Vitamin C, Calcium and Iron.

\section{Cet Less of Theses}

Fat, Saturated Fat, Trans Fat, Cholesterol, Sodium and Sugar
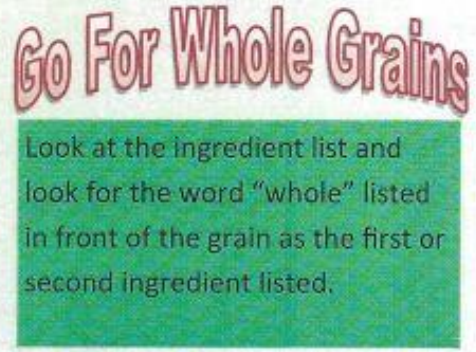

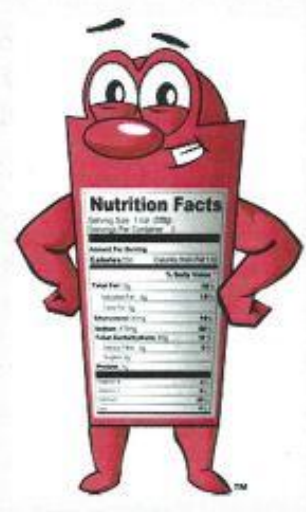

Check out-Make Your Calories Count! An interactive tool to help consumers make decisions about which food is right for them. Use your computer search engine and type in: make your calories count fda.

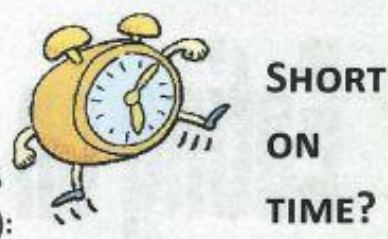

Try these double duty meal tips:

- Brown 95\% leanground beef to use in dishes later in the week like chili and tacos.

- Cook extra chicken breasts and then cut some up to add to a salad or pasta dish later.

- Chop up extra onion and green pepper and store in the fridge for a quick add in.

- Make a large batch of a healthy casserole then store leftovers in the fridge for supper in the next 2-3 days.

For More Information, Go To: http:// www.fda.gov/Food/ LabelingNutrition/ Consumerinformation/ 


\section{Eating on the Rulln}

Convenience foods and eating out options are plentiful for many families. Often families turn to eating out when stressed for time. Many restaurants offer healthy options but sometimes we reach for the big portion meal deals. Eating out too often can lead to an unhealthy diet and excess weight gain.
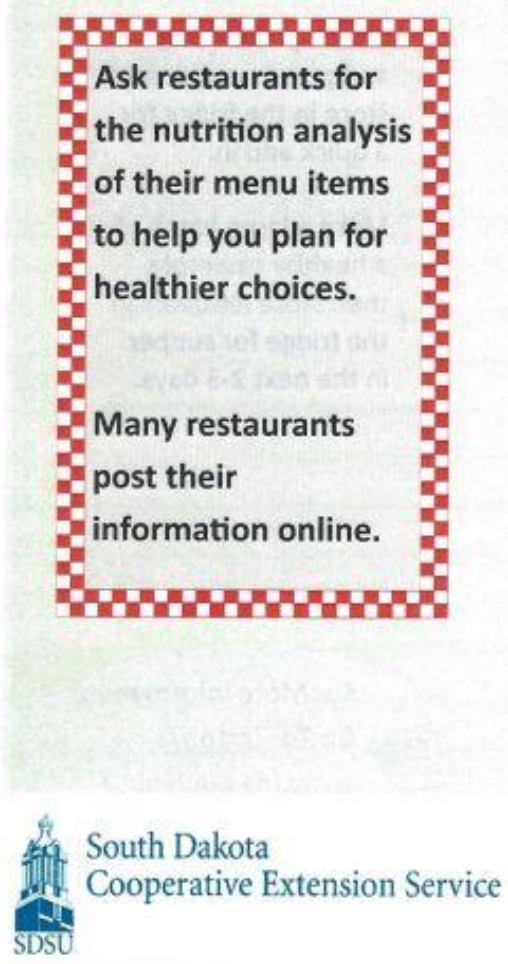

\section{Simple Strategies:}

- Avoid high fat sauces and condiments.

- Ask for lowfat or lite dressings.

- Go for small sides vs. large sides.

- Share a meal and save on calories and \$.

- Choose grilled over breaded and deep fat fried.

- Plan ahead for lunches and meals to give you a head start on healthy eating during hectic weeks.

- Choose water, milk or other low calorie drink items vs. high sugar beverages like soda.

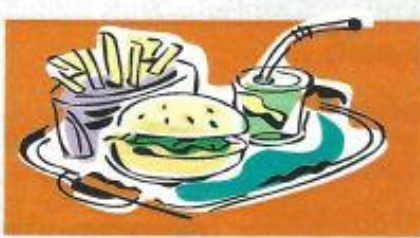

\section{DO THE MATH!}

- A typical $1 / 2$ pound burger with sauce and cheese served with a large fries and a large soda has around 1450 calories and 58 grams of fat.

This amount of fat is equivalent to about 4 Tablespoons of margarine!

- A grilled chicken sandwich without the sauce served with a side salad with light dressing and $1 \%$ milk has around 500 calories and 16 grams of fat.

This amount of fat is equivalent to about 1 Tablespoon of margarinel

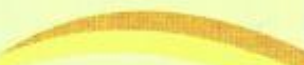




\section{Meal Pack Recipe Cards}

\section{Taco Meatloaf}

Ingredients

$1 \mathrm{lb}$ extra lean ground beef

$\square 1$ egg

$\square$ 1/2 cup whole grain cheddar cheese cracker crumbs

$\square 1$ package low sodium taco seasoning

$\square 3$ to 4 slices American cheese

$\square$ Salsa

Recipe adapted from mealsmatter.org

\section{Crock Pot Chili}

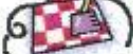

Ingredients

$1 \mathrm{lb}$ extra lean ground beef

1 cup chopped onion

ㄱ 3 (14.5 oz) cans diced tomatoes, undrained

ㄷ 1 (14.5 oz) can Great Northern beans, rinsed and drained

$\square 1$ (14.5 oz) can red kidney beans, rinsed and drained

1 1 (14.5 oz) can corn, drained

$\square 2$ tablespoons chili powder

1 tablespoon cumin

$\square 1$ cup salsa

Recipe from mealsmatter.org
Estimated Time: 45 minutes

Serving Size: 1 inch slice

\section{Instructions}

Combine hamburger, egg, cracker crumbs and taco seasoning and mix well. Place half of the meat mixture into a small loaf pan. Place 3 slices of cheese on top of meat then top off with remaining meat mixture. Cover top with generous amount of salsa and bake in $\mathbf{3 7 5}$ degree oven for about 35 minutes. Remove from oven and top with cheese if desired then return to oven for approximately 10 more minutes until cheese is melted.

\section{Nutrition Facts Per Serving:}

\begin{tabular}{llll|l|l|l|l|} 
Calories & 336 & Total Fat & $19 \mathrm{~g}$ & Sat Fat & $8 \mathrm{~g}$ & Chol & $115 \mathrm{mg}$ \\
& & Total & & & & \\
Sodium & $500 \mathrm{mg}$ & Carbohydrates & $12 \mathrm{~g}$ & Fiber & $2 \mathrm{~g}$ & Protein & $26 \mathrm{~g}$
\end{tabular}

South Dakota

Cooperative Extension Service
Developed by: Becky Jensen, MS, RD, LN, South Dakota State University. July 2011. These materials may be reproduced for educational purposes only.

Educational programs and materials offered without regard for race, color, creed, religion, national origin, ancestry, citizenship, age, gender, sexual orientation, disability, or Vietnam Era Veteran status, South Dakota State University, U.S. Department of Agriculture and county cooperating. An Equal Opportunity Employer. 


\section{Meal Pack Recipe Cards}

\section{Cornbread}

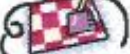

Ingredients

1 cup cornmeal

ㅁ 1 cup flour

1/4 cup sugar

$\square 1$ teaspoon baking powder

$\square 1$ cup low fat $(1 \%)$ milk

$\square \quad 1$ large egg

$\square$ 1/4 cup soft tub margarine

$\square$ nonstick cooking spray

Source: Keep the Beat. NHLBI.US DHHS.

\section{Angel Hair Chicken}

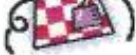

Ingredients

1 cup onion, chopped

1 tablespoon garlic, minced or $2 \mathrm{tsp}$ garlic powder

․ 4 cups broccoli florets (fresh or frozen)

1 tablespoon olive oil

$\square 8 \mathrm{oz}$ very thinly sliced chicken breast, cut in $1 / 2$ inch strips

$\square 1 \mathrm{jar}(26 \mathrm{oz}$ ) lite alfredo sauce

1/4 teaspoon ground cayenne pepper

ㅁ $1 / 2$ teaspoon salt

$\square 8 \mathrm{oz}$ whole wheat angel hair pasta

Source: Keep the Beat. NHLBI.US DHHS.

South Dakota

Cooperative Extension Service
Estimated Time: 45 minutes

Serving Size: 1 square

Makes: 10 servings

Instructions

Preheat oven to 350 degrees. Mix together cornmeal, flour, sugar, and baking powder. In another bowl, combine buttermilk and egg. Beat lightly. Slowly add buttermilk and egg mixture to dry ingredients. Add margarine and mix by hand or with mixer for 1 minute. Bake for 20 to 25 minutes in and 8 by 8 inch baking dish coated with nonstick cooking spray. Cool and cut into 10 squares.

Nutrition Facts Per Serving:

Calories 178 Total Fat $6 \mathrm{~g}$ Sat Fat $1 \mathrm{~g}$ Chol $22 \mathrm{mg}$

Total

Sodium $94 \mathrm{mg}$ Carbohydrates $27 \mathrm{~g}$ Fiber $1 \mathrm{~g}$ Protein $4 \mathrm{~g}$

\section{Instructions}

Chop onion, mince garlic and cut broccoli florets. In a large pan, heat olive oil, add chicken until brown, then add the garlic broccoli and onion and cook for 2 minutes, stirring. Add jar of sauce and seasonings. Mix together, cover and let simmer for about 4 minutes. Cook the pasta according to package directions. Top pasta with chicken mixture.

\section{Nutrition Facts Per Serving:}

\begin{tabular}{llllll|ll} 
Calories & 482 & Total Fat & $10 \mathrm{~g}$ & Sat Fat & $1 \mathrm{~g}$ & Chol & $48 \mathrm{mg}$ \\
& & Total & & & & & \\
Sodium & $412 \mathrm{mg}$ & Carbohydrates & $66 \mathrm{~g}$ & Fiber & $13 \mathrm{~g}$ & Protein & $31 \mathrm{~g}$
\end{tabular}

Developed by: Becky Jensen, MS, RD, LN, South Dakota State University: July 2011. These materials may be reproduced for educational purposes only.

Educational programs and materials offered without regard for race, color, creed, religion, national origin ancestry, citizenship, age, gender, sexual orientation, disability, or Vietnam Era Veteran status. South Dakota State University, U.S. Department of Agriculture and county cooperating. An Equal Opportunity Employer. 


\section{Meal Pack Recipe Cards}

\section{Oven Crusted Chicken} 6Es)

\section{Ingredients}

4 boneless, skinless chicken breasts (3-4 oz each)

$\square 1$ egg white

$\square 1$ cup fat free milk

$\square 1$ cup breadcrumbs

- 1/4 cup quick cooking oatmeal

ㄷ 1 cup whole wheat flour

$\square 2$ tablespoons olive or canola oil

Source: Keep the Beat. NHLBI.US DHHS.

\section{Estimated Time: 40 minutes}

Serving Size: 3 oz

Makes: 4 servings

\section{Instructions}

Pre-heat oven to 350 degrees. Place chicken in a freezer bag with the air squeezed out, and pound each breast down to $1 / 2$ inch thickness. Combine the egg white and milk in a bowl, and mix well. In a separate bowl, combine the breadcrumbs and oats and mix well. Coat the chicken in flour. Dip the chicken in the egg and milk mixture then dip in breadcrumb mixture. Heat oil in a large pan and fry the chicken over medium heat until golden on each side turning carefully. Remove from pan and place on paper towels to soak up oil. Place on baking sheet and finish cooking in the oven for about 8 minutes (internal temp of 165 degrees).

\section{Nutrition Facts Per Serving:}

Calories 480

Total Fat

Total

Sodium $370 \mathrm{mg}$ Carbohydrates $55 \mathrm{~g}$ Fiber $4 \mathrm{~g}$ Protein $38 \mathrm{~g}$

\section{Autumn Salad}

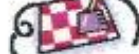

Ingredients

1 apple, rinsed and sliced thinly with skin

ㄴ 2 tablespoons lemon juice

1 bag mixed lettuce greens, rinsed

$1 / 2$ cup dried cranberries

$\square$ 1/4 cup chopped walnuts

1/4 cup unsalted sunflower seeds

- $1 / 3$ cup lowfat raspberry vinaigrette dressing

Source: Keep the Beat. NHLBI.US DHHS.

\section{Instructions}

Sprinkle lemon juice on the apple slices. Mix the lettuce, cranberries, apple, walnuts, and sunflower seeds in a bowl. Toss with raspberry vinaigrette dressing, to lightly cover the salad, and serve.

Estimated Time: 20 minutes

Serving Size: $1 / 2$ cup

Makes: 4 servings$$
\text { salad, and serve. }
$$

\section{Nutrition Facts Per Serving:}

\begin{tabular}{|c|c|c|c|c|c|c|c|}
\hline Calories & 138 & Total Fat & $7 \mathrm{~g}$ & Sat Fat & $1 \mathrm{~g}$ & Chol & $0 \mathrm{mg}$ \\
\hline odium & $41 \mathrm{mg}$ & $\begin{array}{l}\text { Total } \\
\text { Carbohydrates }\end{array}$ & $19 \mathrm{~g}$ & Fiber & $3 \mathrm{~g}$ & Protein & $3 \mathrm{~B}$ \\
\hline
\end{tabular}

South Dakota

Cooperative Extension Service
Developed by: Becky Jensen, MS, RD, LN, South Dakota State University. July 2011. These materials may be reproduced for educational purposes only.

Educational programs and materials offered without regard for race, color, creed, religion, national oripin, ancestry, citizenship, age, gender, sexual orientation, disability, or Vietnam Era Veteran status. South Dakota State University, U.S. Department of Agriculture and county cooperating. An Equal Opportunity Employer. 


\section{Meal Pack Recipe Cards}

\section{Pumpkin Pancakes}

Ingredients

1 cup flour

1 tablespoon sugar

2 teaspoons baking powder

$1 / 2$ teaspoon cinnamon

1 cup $1 \%$ or skim milk

$\square 2$ tablespoons melted butter or margarine

$\square 1$ egg

$\square 1 / 2$ cup canned pumpkin

$\square$ 1/2 cup lowfat vanilla yogurt

Recipe adapted from the National Dairy Council.

\section{Estimated Time: 20 minutes}

Serving Size: 2 four inch pancakes Makes: approximately 8 pancakes

\section{Instructions}

Combine flour, sugar, baking powder and cinnamon in a large mixing bowl. In a medium mixing bowl, combine milk, butter, egg, pumpkin, and yogurt, mixing well. Add wet ingredients to flour mixture and stir until moist, not over mixing. Batter may be lumpy. Using a $1 / 4$ cup ladle, pour batter unto hot griddle and cook pancakes until golden brown on both sides.

Nutrition Facts Per Serving:

Calories 490 Total Fat $10 \mathrm{~g}$ Sat Fat $6 \mathrm{~g}$ Chol $80 \mathrm{mg}$ Total

Sodium $480 \mathrm{mg}$ Carbohydrates $85 \mathrm{~g}$ Fiber $1 \mathrm{~g}$ Protein $16 \mathrm{~g}$

\section{Vegetable Succotash}

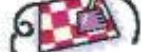

Ingredients

$1 / 4$ cup olive oil

$\square 1$ cup diced onion

$\square 2$ tsp garlic powder

$\square 2$ cups diced red or green bell peppers

$\square 2$ cups diced zucchini

- 2 cups diced yellow summer squash

$\square 3$ cups canned garbanzo beans (drained)

$\square 3$ cups frozen or fresh corn kernels

$\square 2$ tablespoons chopped sage

Recipe adapted from

www.fruitsandveggiesmorematters.gov

\section{Estimated Time: 20 minutes}

Serving Size: 1 cup

Makes: 8 cups

\section{Instructions}

In a skillet over medium high heat, add oil. Add onion; cook 2 minutes. Add garlic, bell peppers, zucchini, squash, beans, and corn. Season as desired; cook, stirring, until vegetables are tender (10 minutes). Stir in sage and serve.

\section{Nutrition Facts Per Serving:}

$\begin{array}{llllllll}\text { Calories } & 220 & \text { Total Fat } & 8 \mathrm{~g} & \text { Sat Fat } & 1 \mathrm{~g} & \text { Chol } & 0 \mathrm{mg} \\ & & \text { Total } & & & & \\ \text { Sodium } & 40 \mathrm{mg} & \text { Carbohydrates } & 35 \mathrm{mg} & \text { Fiber } & 7 \mathrm{~g} & \text { Protein } & 8 \mathrm{~g}\end{array}$

Sh. South Dakota
SDSU

Developed by: Becky Jensen, MS, RD, LN, South Dakota State University July 2011. These materials may be reproduced for educational purposes only.

Educational programs and materials offered without regard for race, color, creed, religion, national origin ancestry, citizenship, age, gender, sexual orientation, disability, or Vietnam Era Veteran status. South Dakot. State University, U.S. Department of Agriculture and county cooperating. An Equal Opportunity Employer. 


\section{Meal Pack Quest Challenge}

\section{Quest Challenges to Trys}

Put a check in the box when the following challenges are completed.

$\square$ I ate 5 meals at home with at least one other member of my family in the last week.

Put a slash thru the number below to help you keep track of when you have reached 5 times: $\begin{array}{lllll}1 & 2 & 3 & 4 & 5\end{array}$

$\square$ One or more members of my family tried one or more of the recipes in this meal pack.

$\square$ I talked with my parents about healthy meals I like that we could have at our house.

$\square$ I helped my parents prepare a meal at least 3 times in the last week.

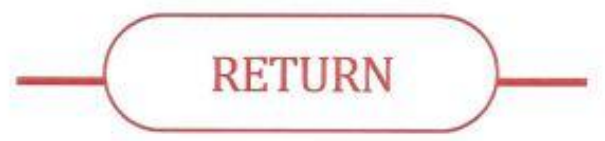

Bring this sheet back to the classroom.

Keep the information, tips and recipe sheets.
- Complete as many of the tasks as you can.

- Sign your name on the bottom of the card.

- Have your parent sign their name on the bottom of the card.

- Bring this sheet back to your classroom.

- Pick a prize from the prize box with your teacher's permission.

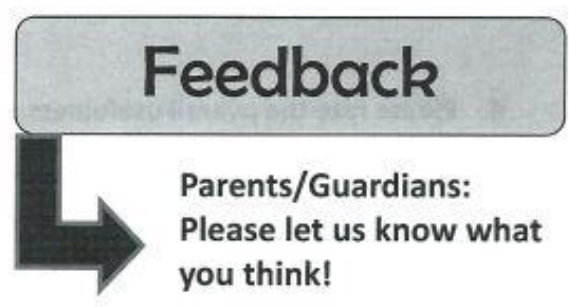

Please take a short survey found on the back of this page.

Youth Signature:

Date:

Parent Signature:

Y

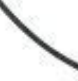

South Dakota

Cooperative Extension Service
Developed by: Becky Jensen, MS, RD, LN, South Dakota State University. July 2011. These materials may be reproduced for educational purposes only.

Educational programs and materials offered without regard for race, color, creed, religion, national origin ancestry, citizenship, age, gender, sexual orientation, disability, or Vietnam Era Veteran status. South Dakota State University, U.S. Department of Agriculture and county cooperating. An Equal Opportunity Employer. 


\section{Feedback}

1. Overall, how would you rate your family's frequency of eating meals at least 5 times at home throughout a week in the following situations?:

a. Before Using the Meal Pack $\square$ Rarely $\square$ Sometimes $\square$ Often

b. After Using the Meal Pack $\quad \square$ Rarely $\square$ Sometimes $\square$ Often

2. The information in the Meal Pack provided us with tips we have used or plan to use: (please $\begin{array}{lllll}\text { check only one answer) } & \square \text { YES }\end{array} \quad$ NO $\quad \square$ UNSURE

3. Please put a check mark by the recipes in the Meal Pack that were tried by at least one member of your family:

$\square \quad$ taco meatloaf

$\square$ crockpot chili

$\square$ cornbread

$\square$ angel hair chicken

$\square$ oven crusted chicken

$\square$ autumn salad

$\square$ pumpkin pancakes

$\square$ vegetable succotash

4. Please rate the overall usefulness of the Meal Pack in helping your family

to achieve and maintain healthy eating habits:
Somewhat useful
Very useful
Not very useful

5. Please comment and or provide suggestions for ways we could improve the Meal Pack in the space below. 


\section{Family Fun Pack 3: Activity Pack}

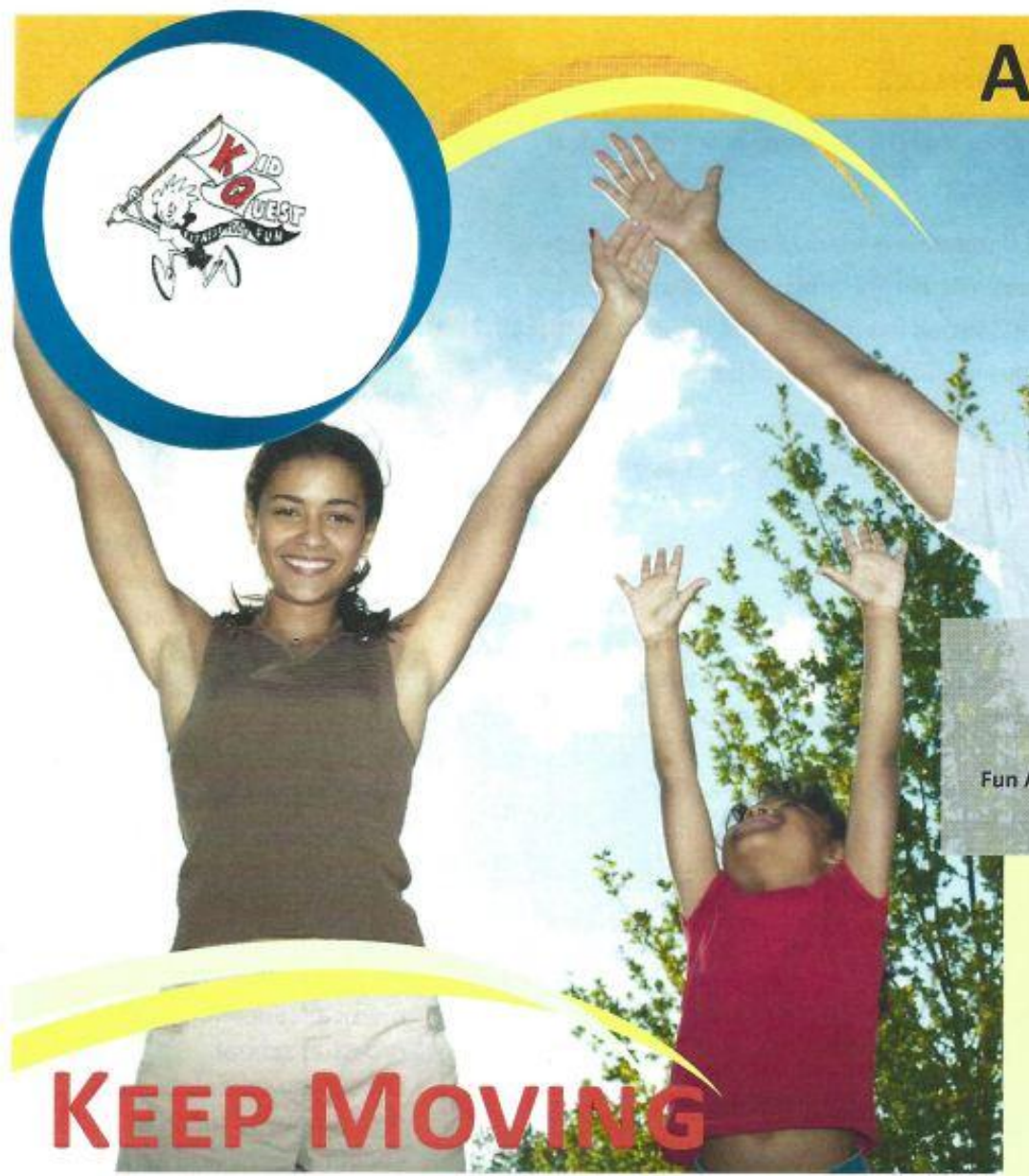

Benefits of Regular Exercise:

Wellness

Decreased risk of illness and disease.

\section{Weight Management}

Helps to control weight without overly restricting food choices.

Increased Energy and Improved Mood

Children don't get tired as frequently and they sleep better. They are also less stressed.

\begin{tabular}{|c|c|}
\hline •Biking & -Skateboarding \\
\hline •Frisbee & -Playing tag \\
\hline -Walking and running & -Swimming \\
\hline - Karate & -Basketball, baseball, volleyball \\
\hline -Football & -Raking leaves \\
\hline
\end{tabular}

\section{Quest Challenges}

The KidQuest program recognizes the very important role family members play in the health of their children. Each of the KidQuest Family Fun Packs contain Quest Challenges. We encourage you to work with your child to complete as many of the Quest Challenges as possible. Children who return a Quest Challenge sheet with their parent's signature will be eligible to redeem a prize (only in participating classrooms)!

\section{FEedBACK WANTED!}

Please let us know what you think by completing the enclosed Feedback information and returning it along with the Quest Challenge information to your KidQuest Youth's classroom. Thank You!

Find Out More At: www.myplate.gov wuw.smallstep.gov 


\section{Physical Activity Guidelines}

- Children and adolescents should do 60 minutes or more of physical activity daily.

- Adults should do at least 150 minutes a week of moderate intensity or 75 minutes a week of vigorous intensity aerobic physical activity. Aerobic activity should be performed in episodes of a least 10 minutes. Adults should also include muscle strengthening activities that involve all major muscle groups on 2 or more days a week.

Source: 2010 Dietary Guidelines for Americans. http://www.cnpp.usda.gov/ Publications/DietaryGuidelines/2010/PclicyDoc/PolicyDoc.pdf

\section{Set Some Goals}

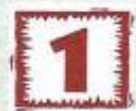

Make exercise a family event. Pick activities the whole family can enjoy and do together.

Think about the best times to fit in an activity throughout the day and week.

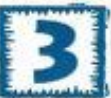

Involve the whole family in making a list of activities.

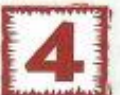

Then, set some goals and keep track of physical activity.

Reward accomplished goals with non-food rewards such as a family bowling night.

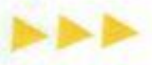

Studies show that kids who believe they are competent and have the skills to be physically active are more likely to be active. Those who feel supported by friends and family or are surrounded by others interested in physical activity, are more likely to participate. Kids should participate in physical activity for at least 60 minutes every day, but it doesn't have to occur all at once. It all adds up! And remember, sleep is an essential part of living a healthy life. A recent study found that with each extra hour of sleep, the risk of a child's being overweight or obese dropped by 9 percent. (source: letsmove.gov)

\section{TIPS from letsmove.gov}

- Give children toys that encourage physical activity like balls, kites, and jump ropes.

- Encourage children to join a sports team or try a new physical activity.

- Limit TV time and keep the TV out of a child's bedroom.

- Facilitate a safe walk to and from school once a week.

- Take the stairs instead of the elevator.

- Walk around the block after a meal.

- Make a new house rule: no sitting still during television commercials.

- Talk to the principal or write a letter to the district superintendent if you think there should be more physical education and recess at school.

- Encourage schools to hold recess prior to lunch to encourage physical activity before mealtime.

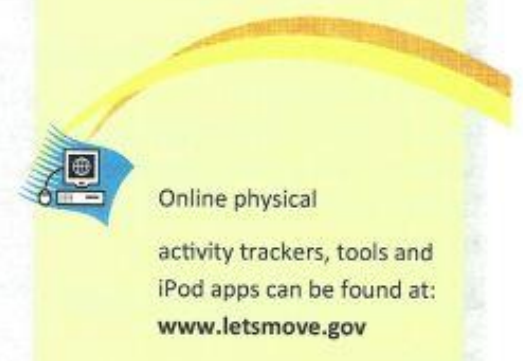

South Dakota Cooperative Extension Service
Developed by: Becky Jensen, MS, RD, LN, South Dakota State University. July 2011. These materials may be reproduced for educational purposes only. Contact: becky.jensen @esdstate.edu

Educational programs and materials offered without regars for race, color, creed, religion, national origin, ancestry, citizenship, age, gender, sexual onlentation, disability, or Vietnam Era Veteran status. South Dakota State University, U.S. Depart ment of Agriculture and county cooperating. An Equal Opportunity Employer. 


\section{Activity Ideas}




\section{Activity Ideas}
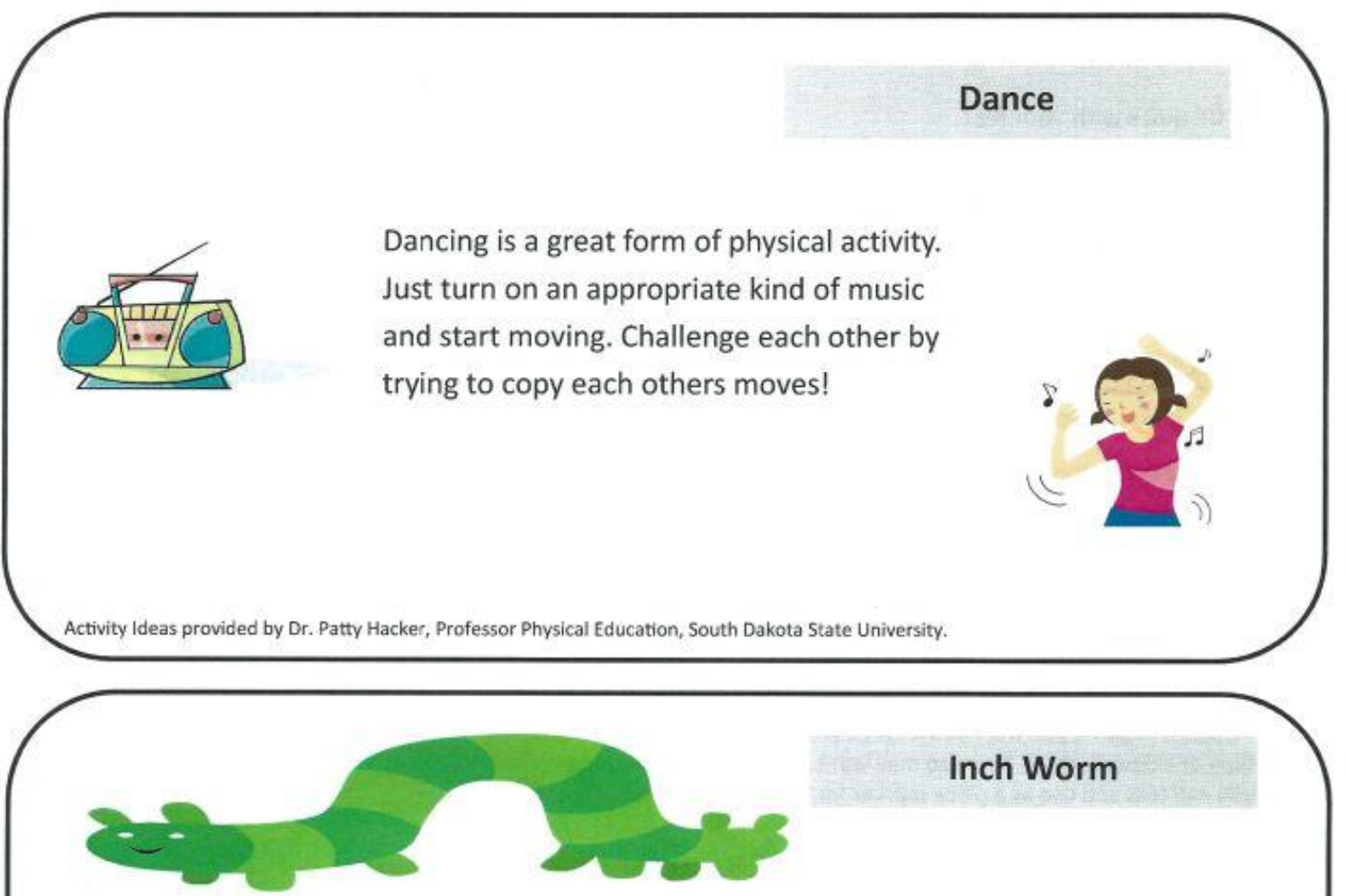

Inch Worm

- Begin by squatting with hands and feet on the floor, and the seat high in the air.

- Slowly walk the feet towards the hands. Then, walk the hands away from the feet as far as possible. Continue walking from feet to hands, then walking hands away, like a worm.

Activity Ideas provided by Dr. Patty Hacker, Professor Physical Education, South Dakota State University.

Developed by: Becky Jensen, MS, RD, LN, South Dakota State University. July 2011. These materials

South Dakota may be reproduced for educational purposes only.

Cooperative Extension Service

Educational programs and materials offered without regard for race, color, creed, religion, national origin, ancestry, citizenship, age, gender, sexual orientation, disability, or Vietnam Era Veteran status. South Dakota State University, U.S. Department of Agriculture and county cooperating. An Equal Opportunity Employer. 


\section{Activity Ideas}

To do this activity you need enough space to have participants lie down on the floor without touching each other. You can have soft music playing.

\section{Relax to the Max}

- Have participants lie down on the floor, close their eyes and breathe slowly.

- Using a calm voice, the parent/adult instructs participants to perform movements such as "staying in position on your back, squeeze together your toes and arches on each foot and then relax them."

- Then instruct participants to tense and relax other body parts, such as their calves, stomachs, fists, and so on.

- Next, encourage participants to take long, slow breaths and fill their lugs up by pretending to smell their favorite food; and then to exhale slowly, as if they are blowing a feather to keep it in the air above their faces.

- After stretching various body parts, participants continue to lie on their backs, breathe slowly and "melt into the floor." Once relaxed, give participants fun visual prompts, like pretending they are in a raft floating down a river, or on a magic carpet in the sky.

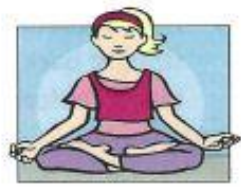

Activity Ideas provided by Dr. Patty Hacker, Professor Physical Education, South Dakota State University.

\section{Jump Rope Skills}

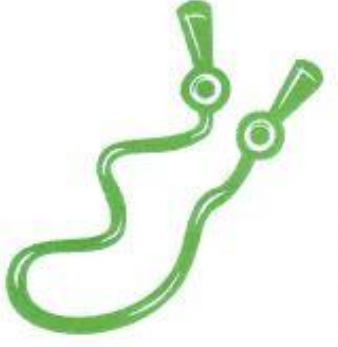

- For this activity you will need to have a single jump rope that fits you and is easy to jump with. When you jump keep your arms at your sides and your hands about waist-high while jumping.

- Turn the rope in small circles using your writs to make the circles. Jump on the balls of your feet first, starting slowly. Bend your knees to make the jumps easier. And, remember to use small jumps!

- Then, try to do some different skills, like jumping with the rope turning backward, jumping with your feet going forward and back over a line, then jumping with your feet going side to side over a line. Then try to make up other skills that will be challenging to do!

Activity Ideas provided by Dr. Patty Hacker, Professor Physical Education, South Dakota State University. 


\section{Activity Ideas}

More OF
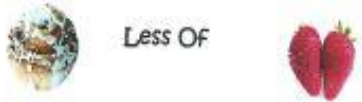

More of

More Of and Less Of

- To do this activity you need a large area to move in (if you have room in your living room or basement or family room, that would work, or it can be played in the yard).

- Divide players into two groups. Designate one group as the "More Of" foods, and the other group as the "Less Of" foods. "More Of" foods are those foods you can eat anytime you are hungry (such as apples, carrots, etc.). "Less Of" foods are those foods you should eat only occasionally when you are hungry (like cookies, candy, etc.). Teams should stand facing each other about three feet apart, with lots of space behind them.

- Have someone call out the name of a food. If it is a "More Of" food, that team quickly takes three steps straight back. At the same time the other team is trying to tag the "More Of" members nearest them. If tagged before taking three steps back, that person must become part of the opposite team.

Activity Ideas provided by Dr. Patty Hacker, Professor Physical Education, South Dakota State University.

Each of these activities works on flexibility, which is important for doing everyday activities we are involved in. Do each of these exercises at least 3 times.

- Sit on the floor with legs straight out in front of you. Sit up tall and gently lean out over your legs toward your toes. Each day that you do this exercise try to stretch out farther.

- Sit with legs split, forming a "V." Sit up tall and gently lean out over each leg and then straight forward to the middle. Each day that you do this exercise try to stretch out farther.

- Sit with the soles of your shoes together, with your legs forming a diamond shape. Gently lean out over the diamond toward your toes. Each day you do this exercise try to lean out a little farther.

\section{Lower Body Flexibility}

Hey Kids! May I Have Your

Attention PLEASE!

When doing your stretches, make sure that you DO NOT bounce! Bouncing could cause you to hurt yourself, so do gentle stretches instead!

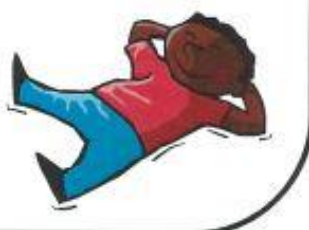

Activity Ideas provided by Dr. Patty Hacker, Professor Physical Education, South Dakota State University.

Developed by: Becky Jensen, MS, RD, LN, South Dakota State University. July 2011 . These materials may be reproduced for educational purposes only.

South Dakota

Cooperative Extension Service

Educational programs and materials offered without regard for race, color, creed, religion, national origin, ancestry, citizenship, age, gender, sexual orlentation, disability, or Vietnam Era Veteran status. South Dakota State University, U.S. Department of Agriculture and county cooperating. An Equal Opportunity Employer. 


\section{Activity Pack Quest Challenge}

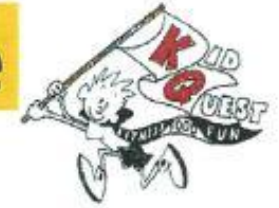

\section{Quest Challenges to Trys}

Put a check in the box when the following challenges are completed.

I did 60 minutes total of any kind of physical activity on at least 5 days in the past week.

Put a slash thru the number below to help you keep track of when you have reached 5 times: $\begin{array}{llllll}1 & 2 & 3 & 4 & 5\end{array}$

I tried one or more of the activities in the Activity Pack.

$\square$ I talked with my parents about physical activities I thought we could all do as a family.

$\square$ Myself and at least one other member of my family did any kind of physical activity together for at least 15 minutes.

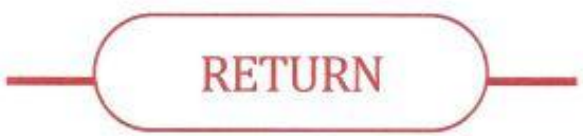

Bring this sheet back to the classroom.

Keep the information, tips and recipe sheets.
- Complete as many of the tasks as you can.

- Sign your name on the bottom of the card.

- Have your parent sign their name on the bottom of the card.

- Bring this sheet back to your classroom.

- Pick a prize from the prize box with your teacher's permission.

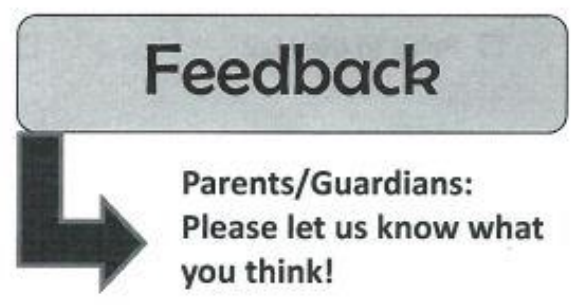

Please take a short survey found on the back of this page.

Youth Signature:

Date:

Parent Signature:

Date:

South Dakota

Developed by: Becky Jensen, MS, RD, LN, South Dakota State University, July 2011. These materials may be reproduced for educational purposes only. 


\section{Feedback}

1. Overall, how would you rate your family's frequency of doing any kind of physical activity together throughout a typical week in the following situations?:

a. Before Using the Activity Pack $\quad \square$ Rarely $\square$ Sometimes $\square$ Often

b. After Using the Activity Pack $\square$ Rarely $\square$ Sometimes $\square$ Often

2. The information in the Activity Pack provided us with tips we have used or plan to use: (please check only one answer) $\quad \square$ YES $\square$ NO $\square$ UNSURE

3. Please put a check mark by the activities in the Activity Pack that were tried by at least one member of your family:

$\square$ More of and less of

$\square$ Footsie

$\square$ Lower body flexibility

$\square$ Hopscotch

$\square$ Inch worm

$\square \quad$ Jump rope

$\square$ Relax to the Max

$\square$ Dance

4. Please rate the overall usefulness of the Activity Pack in helping your family to achieve and maintain healthy physical activity habits:
Somewhat useful
Very useful
Not very useful

5. Please comment and or provide suggestions for ways we could improve the Activity Pack in the space below. 


\section{Family Fun Pack 4: Screen Pack}

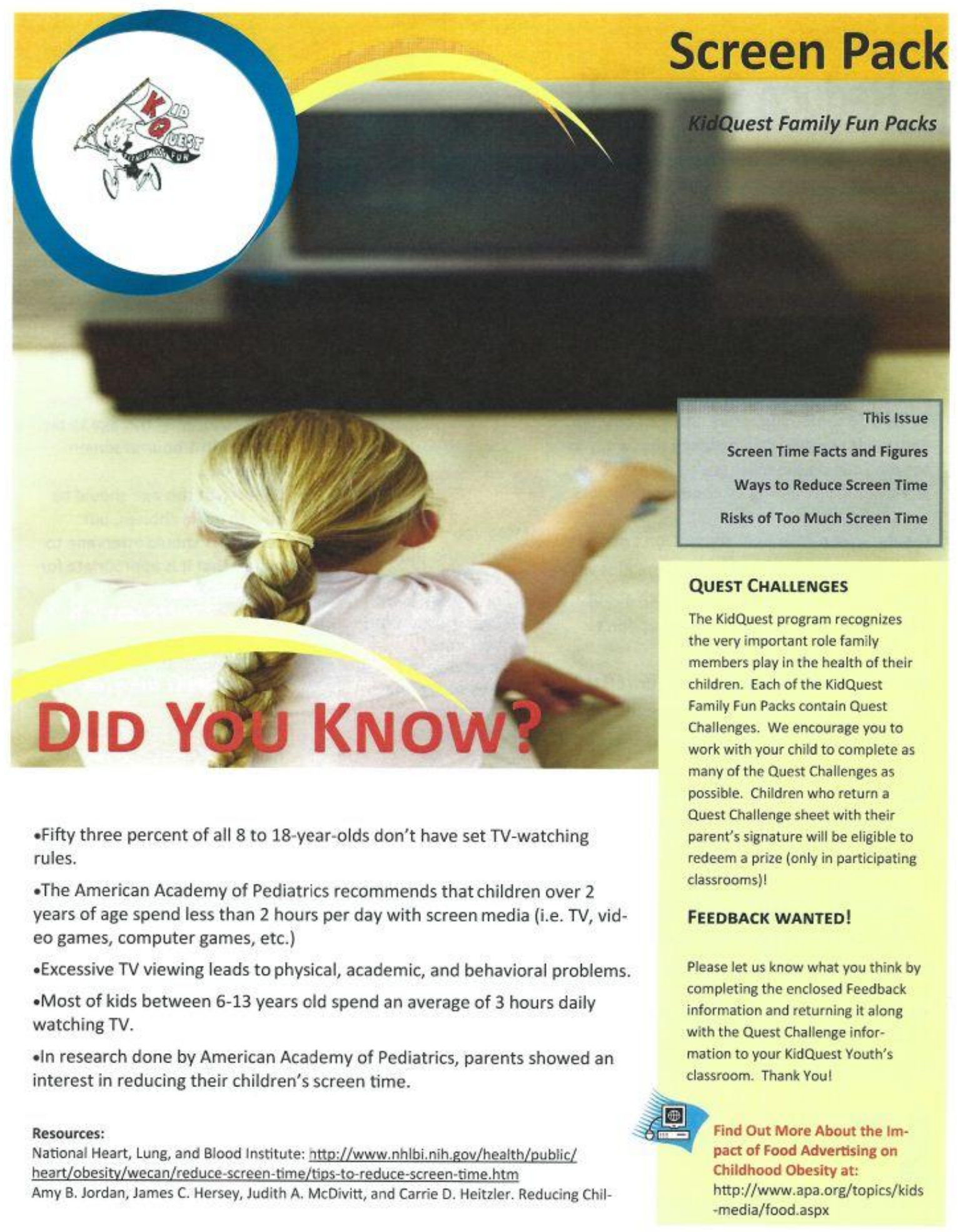




\section{Reduce Screen Time}

Talk to Your Family: Explain to your kids that it's important to sit less and move more in order to stay at a healthy weight.

Set a Good Example: Be a good parental role model and limit your family's screen time to no more than two hours per day.

Log Screen Time vs. Active Time: Start tracking how much time your family spends in front of a screen, including things like TV-and DVD-watching, playing video games, and using the computer.

Make Screen Time Active Time: When you do spend time in front of the screen, do something active. Stretch, do yoga and/or lift weights. Or, challenge the family to see who can do the most push-ups, jumping jacks, or leg lifts during TV commercial breaks.

Create Screen-Free Bedrooms: Don't put a TV or computer in your child's bedroom. Kids who have TVs in their room tend to watch about 1.5 hours more TV a day than those that don't .

Make Meal Time a Family Time: Turn off the TV during meals. Better yet, remove the TV from the eating area if you have one there.

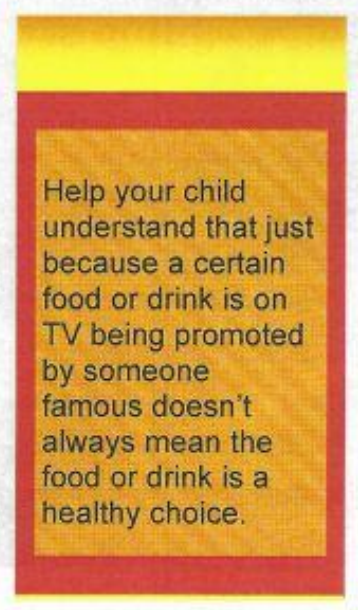

Don't Use Screen Time as Reward or

Punishment: Practices like this make screen time seem even more important to children.

Understand TV Ads \& Placements: Help your child understand that because it's on TV-or your favorite TV characters/actors eat or drink it-doesn't mean a food or drink is good for you.

Resources: NIH: http://www.nhlbi.nih.gov/health/public/heart/obesity/wecan/reduce-screen-time/ tips-to-reduce-screen-time.htm

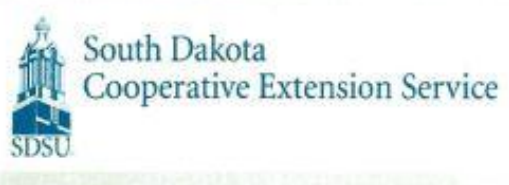

\section{Age Limits for Screen Time}

Infant Children ( $0-2$ years)

The American Academy of Pediatrics (AAP) does not recommend television for children this young.

Toddler Children (2-3 years) Limit children of this age to no more than a $1 / 2$ hour of screen time a day.

Appropriate shows and games for children of this age group that are both educational and fun.

Preschool Children (3-5 years) Limit children of this age to no more than 1 hour of screen time a day.

Children at this age should be able to make choices, but caregivers should intervene to assure that it is appropriate for the age-group.

Kindergarten Children (5-6 years)

Limit children of this age to 1 to $1 \frac{1}{2}$ hours of screen time a day.

At this age they usually already have their favorite shows or games, but supervision is still necessary for appropriateness of materials.

School-Age Children (6-12 years)

Limit children of this age to 2 to $2 \frac{1}{2}$ hours of screen time a day. Caregivers need to be very selective about what the children are watching and playing.

Resource: wum.lakesandprairies.net/ Screen Time.pdt
Developed by: Becky Jensen, MS, RD, LN, South Dakota State University. July 2011. These materials may be re-

Educational programs and materials offered without regard for race, color, creed, religion, national origin, ancestry, citzenship, age, gender, sexual erientation, disability, or Vietnam Era Veteran status. South Dakota State University, U.S. Department of Agriculture and county cooperating, An Equal Opportunity Employer. 


\section{Screen Pack Quest Challenge}

\section{Quest Challenges to Trys}

Put a check in the box when the following challenges are completed.

I watched less than 2 hours of TV per day for at least 5 of the 7 days in the past week.

$\square$ When I did watch TV, I got up during the commercials and did some stretches or some other type of activity during 3 or more different TV programs in the past week.

My family did not watch any TV during family mealtimes in the past week.

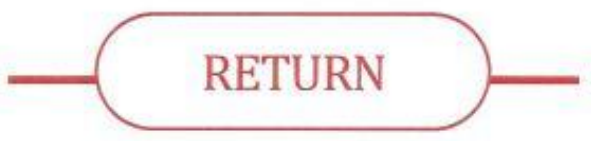

Bring this sheet back to the classroom.

Keep the information, tips and recipe sheets.
- Complete as many of the tasks as you can.

- Sign your name on the bottom of the card.

- Have your parent sign their name on the bottom of the card.

- Bring this sheet back to your classroom.

- Pick a prize from the prize box with your teacher's permission.

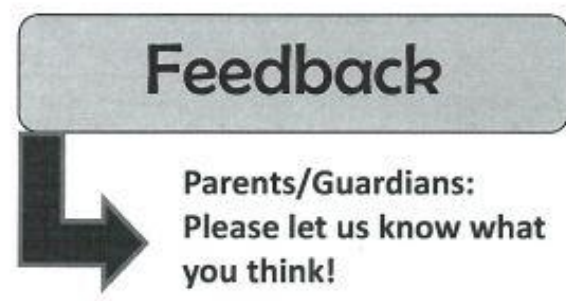

Please take a short survey found on the back of this page.
Youth Signature:

Parent Signature:

Date:

Date:

Developed by: Becky Jensen, MS, RD, LN, South Dakota State University. July 2011. These materials may be reproduced for educational purposes only.

Educational programs and materials offered without regard for race, color, creed, religion, national oriein, ancestry, citizenship, age, gender, sexual orientation, disability, or Vietnam Era Veteran status. South Dakota State University, U.S. Department of Agriculture and county cooperating. An Equal Opportunity Employer. 


\section{Feedback}

1. Overall, how would you rate your child's frequency of watching TV or playing computer games for greater than $\mathbf{2}$ hours per day in the following situations?:

A. Before Using the Screen Time Pack: $\quad \square$ Rarely $\square$ Sometimes $\square$ often

B. After Using the Screen Time Pack: $\quad \square$ Rarely $\square$ Sometimes $\square$ Often

2. The information in the Screen Time Pack provided us with tips we have used or plan to use: (please check only one answer)

$$
\square \text { YES } \square \text { NO } \square \text { UNSURE }
$$

3. Please rate the overall usefulness of the Screen Time Pack in helping your family to decrease overall time spent in screen time activities:
$\square$ Somewhat useful
$\square$ Very useful
Not very useful

4. Please comment and or provide suggestions for ways we could improve the Screen Time Pack in the space below:

\section{THANK YOU}

